\title{
GROUND- AND SURFACE-WATER INTERACTION BETWEEN THE KANSAS RIVER AND ASSOCIATED ALLUVIAL AQUIFER, NORTHEASTERN KANSAS
}

U.S. GEOLOGICAL SURVEY

Water-Resources Investigations Report 92-4137

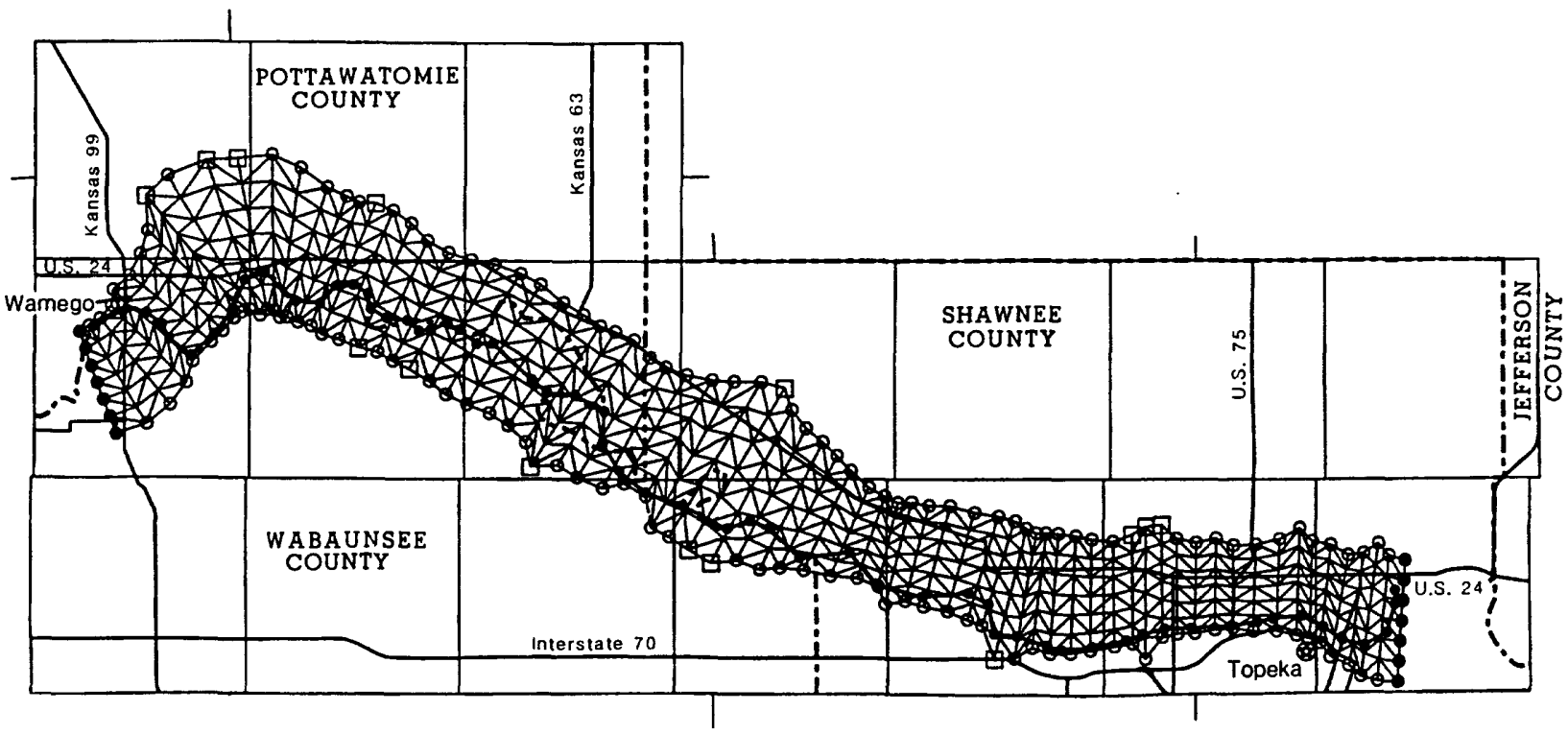

Prepared in cooperation with the U.S. BUREAU OF RECLAMATION

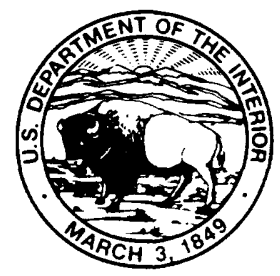


GROUND- AND SURFACE-WATER INTERACTION BETWEEN THE KANSAS RIVER AND ASSOCIATED ALLUVIAL AQUIFER, NORTHEASTERN KANSAS

By R.J. Wolf and J.O. Helgesen

U.S. GEOLOGICAL SURVEY

Water-Resources Investigations Report 92-4137

Prepared in cooperation with the

U.S. BUREAU OF RECLAMATION

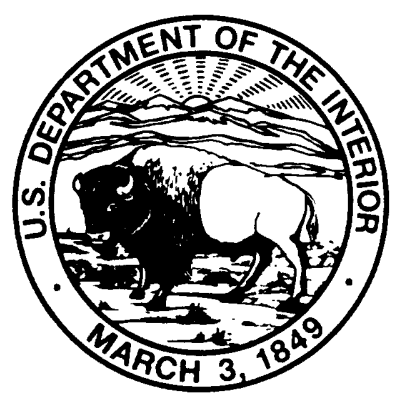

Lawrence, Kansas

1993 


\title{
U.S. DEPARTMENT OF THE INTERIOR
}

\author{
MANUEL LUJAN, JR., Secretary
}

\section{U.S. GEOLOGICAL SURVEY}

\author{
Dallas L. Peck, Director
}

For additional information write to:

District Chief

U.S. Geological Survey

Water Resources Division

4821 Quail Crest Place

Lawrence, Kansas 66049-3839
Copies of this report can be purchased from:

U.S. Geological Survey Books and Open-File Reports Denver Federal Center Box 25425

Denver, Colorado 80225 


\section{CONTENTS}

Page

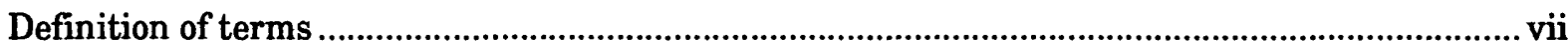

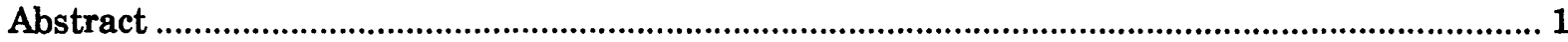

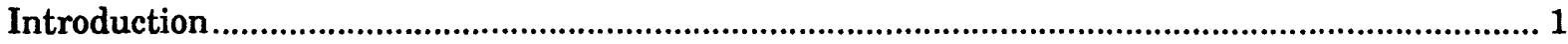

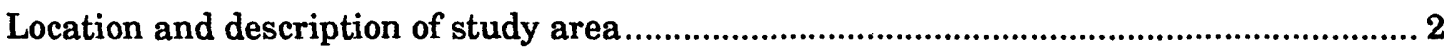

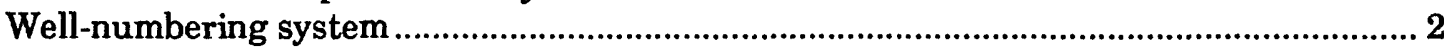

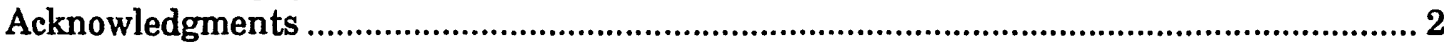

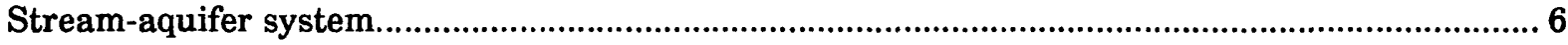

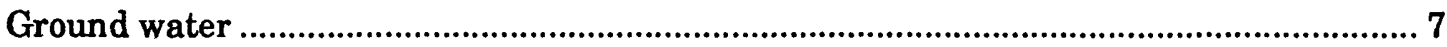

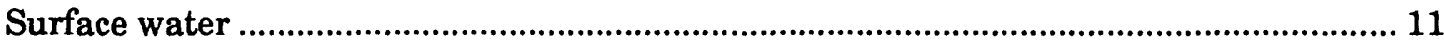

Mathematical representation of stream-aquifer system ..................................................... 11

Digital model description and construction ................................................................. 15

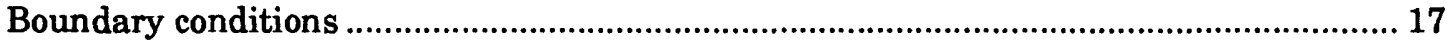

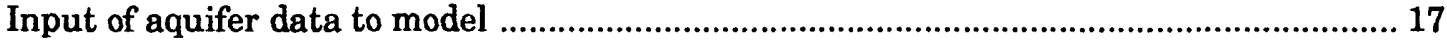

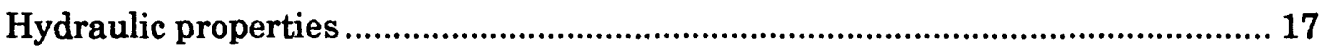

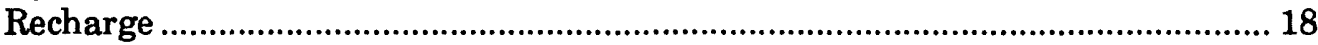

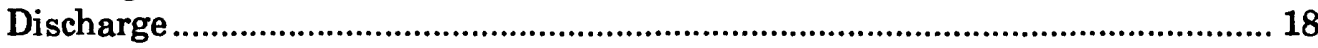

Pumpage ............................................................................................ 18

Stream-aquifer interchange ............................................................... 19

Evapotranspiration ........................................................................ 23

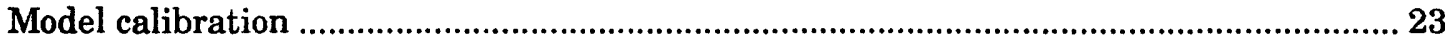

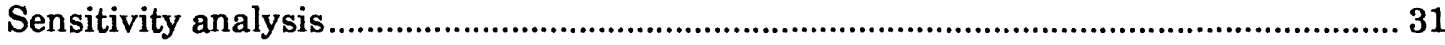

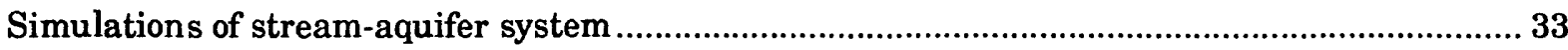

Simulations 1-3: Above-average streamflow and precipitation with variations of

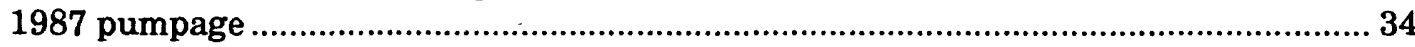

Simulations 4-6: Near-average streamflow and precipitation with variations of

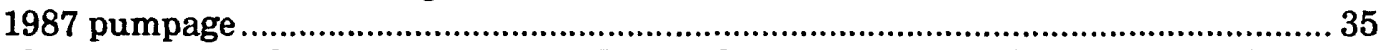

Simulations 7-9: Below-average streamflow and precipitation with variations of

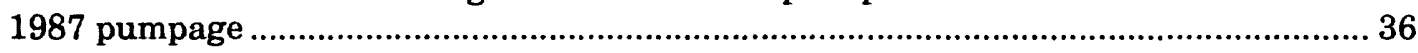

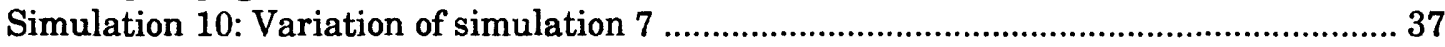

Simulations 11-13: Variation of simulation 10, changes in river discharge/reservoir

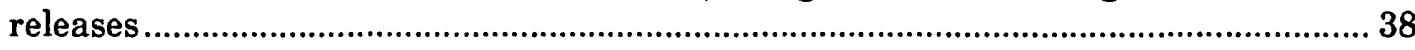

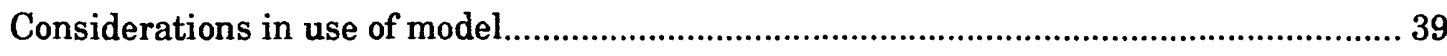

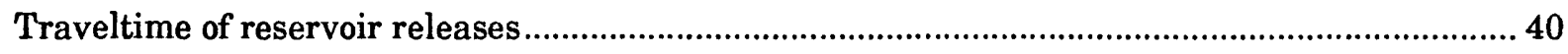

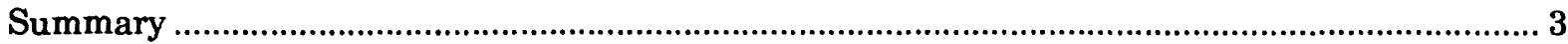

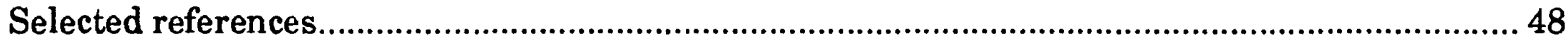




\section{ILLUSTRATIONS}

Page

Figures 1-2. Map showing:

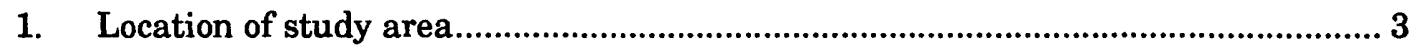

2. Mean annual precipitation in Kansas River valley, 1951-80 ............................... 4

Figures 3-4. Diagram showing:

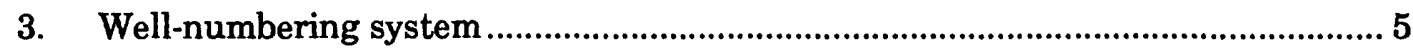

4. Generalized hydrologic cycle and flow directions in Kansas River valley .............. 6

5. Graphs showing water-level profiles in the alluvial aquifer adjacent to Kansas River

Figures 6-7. Map showing:

6. Altitude of water table in modeled area, February-March 1987

7. Location of observation wells with multiple measurements in modeled area 10

8. Example hydrograph of measured water level, 1950-87.

Figures 9-10. Map showing:

9. Location of streamflow-gaging stations in vicinity of study area........................ 12

10. Finite-element model grid and boundary conditions ..................................... 16

11. Graph showing number of permits for large-capacity wells in modeled area, 1948-87....

Figures12-14. Map showing:

12. Location of pumped wells in modeled area, 1987

13. Location of wells used to simulate tributaries and river nodes used to represent either tributary inflow or surface-water diversions

14. Simulated water-table contours for March 15, 1987, and water-table contours based on water levels measured during February-March 1987.

Figure 15-17. Hydrographs showing:

15. Measured and simulated water levels in western part of modeled area 28

16. Measured and simulated water levels in eastern part of modeled area 29

17. Measured and simulated monthly mean discharge of Kansas River at Topeka for 1963-67 and 1983-87 30 


\section{ILLUSTRATIONS--Continued}

Figures 18-33. Graph showing:

18. Simulated annual mean drawdown in alluvial aquifer in modeled area, 1948-87

19. Simulated annual mean net stream-aquifer leakage in the Kansas River valley from Wamego to Topeka, 1948-87

20. Simulated annual mean net stream-aquifer leakage for western and eastern reaches of the Kansas River in modeled area, 1948-87.

21. Simulated stream-aquifer leakage at each river node for December 27-31, 1987

22. Monthly precipitation and simulated evapotranspiration, 1948-87

23. Monthly simulated deep percolation and estimated pumpage, 1948-87.

24. Monthly surface-water diversions from Kansas River and simulated ground-water evapotranspiration, 1948-87

25. Effects of variations in precipitation, hydraulic conductivity, streambed leakance, and specific yield on simulated water levels, spring 1987

26. Annual mean drawdown in alluvial aquifer for entire modeled area for 8year hypothetical simulations 1-9

27. Annual mean net stream-aquifer leakage along entire Wamego-Topeka Kansas River reach for 8-year hypothetical simulations 1-9.

28. Effect of simulated reservoir releases during hypothetical drought conditions on August 8 in 8th year of simulations.

29. Stream-aquifer leakage at each model river node on August 8 in 8 th year of simulation 10

30. Percentage loss of simulated reservoir releases at each model river node on selected days after initial release.

31. Percentage loss of simulated reservoir release of 100 cubic feet per second at selected points downstream during 10 -day release period.

32. Traveltime of selected historical reservoir-release rises from Milford Lake

33. Traveltime of selected historical reservoir-release rises from Tuttle Creek Lake 


\section{TABLES}

\section{Page}

Table 1. U.S. Geological Survey streamflow-gaging stations in vicinity of study area ...... 13

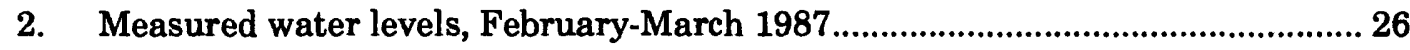

3. Simulated average water budget for Kansas River alluvial aquifer between Wamego and Topeka, 1948-87 ............................................................................. 32

4. Velocities for isolated historical reservoir-release rises from Milford and Tuttle

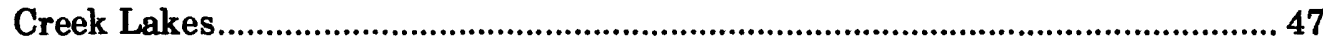




\section{CONVERSION FACTORS AND VERTICAL DATUM}

\section{Multiply}

acre

acre-foot

acre-foot per year

cubic foot

cubic foot per second

foot

foot per mile

gallon per minute

inch

mile

mile per hour

square foot

square mile
By

0.4047

1,233

1,233

0.02832

0.02832

0.3048

0.1894

0.06309

25.4

1.609

1.609

0.09290

2.590
To obtain

hectare

cubic meter

cubic meter per year

cubic meter

cubic meter per second

meter

meter per kilometer

liter per second

millimeter

kilometer

kilometer per hour

square meter

square kilometer

Sea level: In this report, "sea level" refers to the National Geodetic Vertical Datum of 1929-a geodetic datum derived from a general adjustment of the first-order level nets of the United States and Canada, formerly called Sea Level Datum of 1929. 


\section{DEFINITION OF TERMS}

Bank storage

Channel storage

Evapotranspiration

Hydraulic conductivity

Hydraulic flux

Hydraulic gradient

Hydraulic head

Streambed leakance

Porosity

River stage

Saturated zone

Soil-moisture deficiency

Specific yield

Storage coefficient

Water table
Change in storage in an aquifer resulting from a change in stage of an adjacent surface-water body.

Volume of water at a given time in the channel or over the flood plain of the streams in a drainage basin or river reach.

Volume of water that is lost to the atmosphere by transpiration from vegetative growth and by evaporation from the soil or from the aquifer in shallow water-table areas.

Volume of water at the existing kinematic viscosity that will move through a porous medium in unit time under a unit hydraulic gradient through a unit area measured at right angles to the direction of flow. Units of hydraulic conductivity are:

$$
\frac{\left(\text { length }^{3} / \text { time }\right)}{\left(\text { length }^{2}\right)(\text { length/length })}\left(\text { for example, } \frac{\left(\text { feet }^{3} / \text { day }\right)}{\left(\text { feet }^{2}\right)(\text { feet/feet })}\right)
$$

but, as in this report, commonly are reported in the mathematically reduced form as length/time (feet/day, for example).

Volumetric rate of flow of water across an interface.

Rate of change in total hydraulic head per unit of distance of flow in a given direction.

Height of the surface of a column of water above a standard datum that can be supported by the pressure at a point.

Ratio of hydraulic conductivity of streambed, in feet per day, to thickness of streambed, in feet.

Ratio of the volume of void spaces in a rock or sediment to the total volume of the rock or sediment.

Height of a river surface above an established datum plane.

Subsurface zone in which all openings are full of water.

Ratio of (1) the volume of water which the rock or sediment, after being saturated, will yield by gravity to (2) the total volume of the rock or sediment.

Ratio of the volume of water that the saturated material will yield by gravity drainage to the volume of the material.

Volume of water of an aquifer releases from or takes into storage per unit surface area per unit change in hydraulic head.

Level in the saturated zone at which the pressure is equal to the atmosphere pressure. 


\title{
GROUND- AND SURFACE-WATER INTERACTION BETWEEN THE KANSAS RIVER AND ASSOCIATED ALLUVIAL AQUIFER, NORTHEASTERN KANSAS
}

\author{
By R.J. Wolf and J.O. Helgesen
}

\section{ABSTRACT}

Water in the Kansas River valley alluvial aquifer between Wamego and Topeka, Kansas, has been intensively developed without a general decline of water levels. To evaluate the stream-aquifer system and the effects of ground-water development, a finite-element model was used to simulate transient flow and water-level conditions for the 40-year period, 1948-87, and to implement 8-year hypothetical simulations of below-average, near-average, and above-average streamflow and precipitation. Model calibration for the aquifer involved both spatial and temporal comparisons of measured and simulated water levels until a satisfactory match was achieved. Calibration of the streamflow component of the model consisted of comparisons of measured and simulated monthly discharge of the Kansas River at the stream-gaging station at Topeka. The simulated discharge generally agreed with the measured discharge.

Average recharge to the aquifer from 1948 to 1987 resulting from deep percolation of precipitation and applied irrigation water simulated by the model was about $84 \mathrm{ft}^{3} / \mathrm{s}$ (cubic feet per second). Lateral inflow was about $7 \mathrm{tt}^{3} / \mathrm{s}$. Simulated average discharge from the aquifer was about $42 \mathrm{ft}^{3} / \mathrm{s}$ for pumpage, $27 \mathrm{ft}^{3} / \mathrm{s}$ for net stream-aquifer leakage to the main stem Kansas River, $15 \mathrm{ft}^{3} / \mathrm{s}$ for discharge to tributaries, $9 \mathrm{ft}^{3} / \mathrm{s}$ for ground-water evapotranspiration, and $3 \mathrm{ft}^{3} / \mathrm{s}$ for downgradient lateral outflow. Simulated recharge to the aquifer from all sources averaged about 98 $\mathrm{ft}^{3} / \mathrm{s}$ for the 1948-87 period. Simulated discharge averaged about $96 \mathrm{ft}^{3} / \mathrm{s}$ during that period; thus, the volume of water in storage increased at an average rate of about $2 \mathrm{ft}^{3} / \mathrm{s}$. Yearly water-level variations reflect precipitation variations, and the average water-level rise across the area during the 40-year simulation period was about 4 feet. Results of simulated yearly mean net streamaquifer leakage during 1948-87 indicated that the aquifer generally discharged to the stream.
Thirteen 8-year model simulations show the effects of years of above-average, near-average, and below-average streamflow and precipitation coupled with various hypothetical pumpage options. Model results show average simulated water-level rises of about 2 to 4 feet for above-average streamflow and precipitation conditions, declines of about 2 to 4 feet for near-average conditions, and declines of about 6 to 10 feet for below-average conditions. The simulation of below-average streamflow and precipitation conditions was the basis for simulated 10-day upstream reservoir releases of 50,100 , and $500 \mathrm{ft}^{3} / \mathrm{s}$ during severe drought conditions. Model results show that on the first day of simulated reservoir releases the river is a losing stream at most river nodes. Resulting simulations indicated 1.8 percent of the water released was lost on the first day, about 1.6 percent was lost on the fifth day, and about 1.2 percent was lost on the tenth day. Plots of the loss indicated that losses increased downstream from the release point and the time necessary to reestablish equilibrium conditions after an initial reservoir release increased.

Historical traveltimes of actual reservoirrelease rises in stage from Milford and Tuttle Creek Lakes indicated that the larger the discharge of the release or the larger the antecedent discharge, the faster the rise in stage traveled, thus indicating that the depth of water in the river channel is the main factor affecting traveltimes. Although there were individual increases or decreases in traveltimes between gaging stations, overall average speeds calculated for the 31 releases analyzed ranged from 0.5 to 3.8 miles per hour.

\section{INTRODUCTION}

The State of Kansas is developing a water-management plan for the Kansas River. The river and its associated valley-fill deposits act together as a single, integrated hydrologic system. Understanding the flow of water 
through this system, particularly the effects of ground-water withdrawals on river discharge, and especially during periods of drought, is critical to development of the management plan. Accordingly, the U.S. Geological Survey, in cooperation with the U.S. Bureau of Reclamation, which also is participating in the planning process, conducted a hydrologic study of the Kansas River and its associated alluvial aquifer. The objectives of the study were to (1) determine the effects of pumping on flow in the Kansas River, especially during low-flow periods when reservoir releases are made, and (2) determine traveltimes of reservoir-release rises at various points downstream. This report presents the results of the study.

Although a general assessment of the entire Kansas River valley was made, the Wamego-Topeka area (about 135 square miles) was chosen for detailed study of ground- and surface-water interaction. Preliminary generalized numerical hydrologic models were made for four segments of the river valley between main-stem streamflow-gaging stations, and a detailed digital model of the Wamego-Topeka segment, where development is intensive, was calibrated and used to evaluate past and hypothetical future effects of ground-water development.

\section{Location and Description of Study Area}

The Kansas River alluvial valley extends 138 miles from the confluence of the Republican and Smoky Hill Rivers at Junction City, Kansas, eastward to the mouth of the Kansas River at the Kansas-Missouri State line (fig. 1) and averages about 2.6 miles wide from bluff to bluff. The valley includes parts of the following 10 counties: Douglas, Geary, Jefferson, Johnson, Leavenworth, Pottawatomie, Riley, Shawnee, Wabaunsee, and Wyandotte. The length of the river as measured along the centerline of the meandering channel is about 170 miles; the area covered by valley-fill deposits is 360 square miles.

Topographically, the valley includes the broad flood plain of the Kansas River, flat terraces bordering the flood plain, and bluffs along the edge of the valley. Average slope of the streambed along the 138-mile reach of the river between U.S. Geological Survey streamflowgaging stations at Fort Riley and DeSoto is about 2 feet per mile.

Mean annual precipitation from 1951-80 ranged from about 33 inches at Junction City in the western part of the valley to about 37 inches near Lecompton in the east (fig. 2).

\section{Well-Numbering System}

Locations of wells and test holes in this report are given according to a modified version of the U.S. Bureau of Land Management's system of land subdivision. The well number is composed of digits representing the township, range, and section, followed by letters that indicate the subdivision of the section where the well is located. The first letter denotes the quarter section or 160-acre tract; the second letter denotes the quarter-quarter section or 40-acre tract; the third letter indicates the quarter-quarter-quarter section or 10-acre tract; and the fourth letter, when used, indicates the quarter-quarter-quarter-quarter section or 2.5-acre tract. The 160 -acre, 40-acre, 10-acre, and 2.5-acre tracts are designated A, B, C, and $D$ in a counterclockwise direction, beginning in the northeast quadrant. Any additional wells located within the 10-acre tract are numbered serially, beginning with 2 , in the order in which they were inventoried. For example, well. 09S-11E-32ADB3, with the legal description of NW1/4 SE1/4 NE1/4, sec. 32, T. 9 S., R. 11 E., is the third well inventoried in the northwest quarter of the southeast quarter of the northeast quarter of section 32, township 9 south, range 11 east (fig. 3). For the wellnumbering system to apply in the undesignated, military land grant or old Indian-land areas along the Kansas River, lines were drawn as if the township, range, and section lines extended into those areas.

\section{Acknowledgments}

Information, cooperation, and advice provided by many people helped achieve the objectives of the study. The authors especially appreciate access granted by owners to property and wells in the study area for measurement of water levels and collection of other geohydrologic data. Water-level and water-use data were provided by the Kansas Water Office 


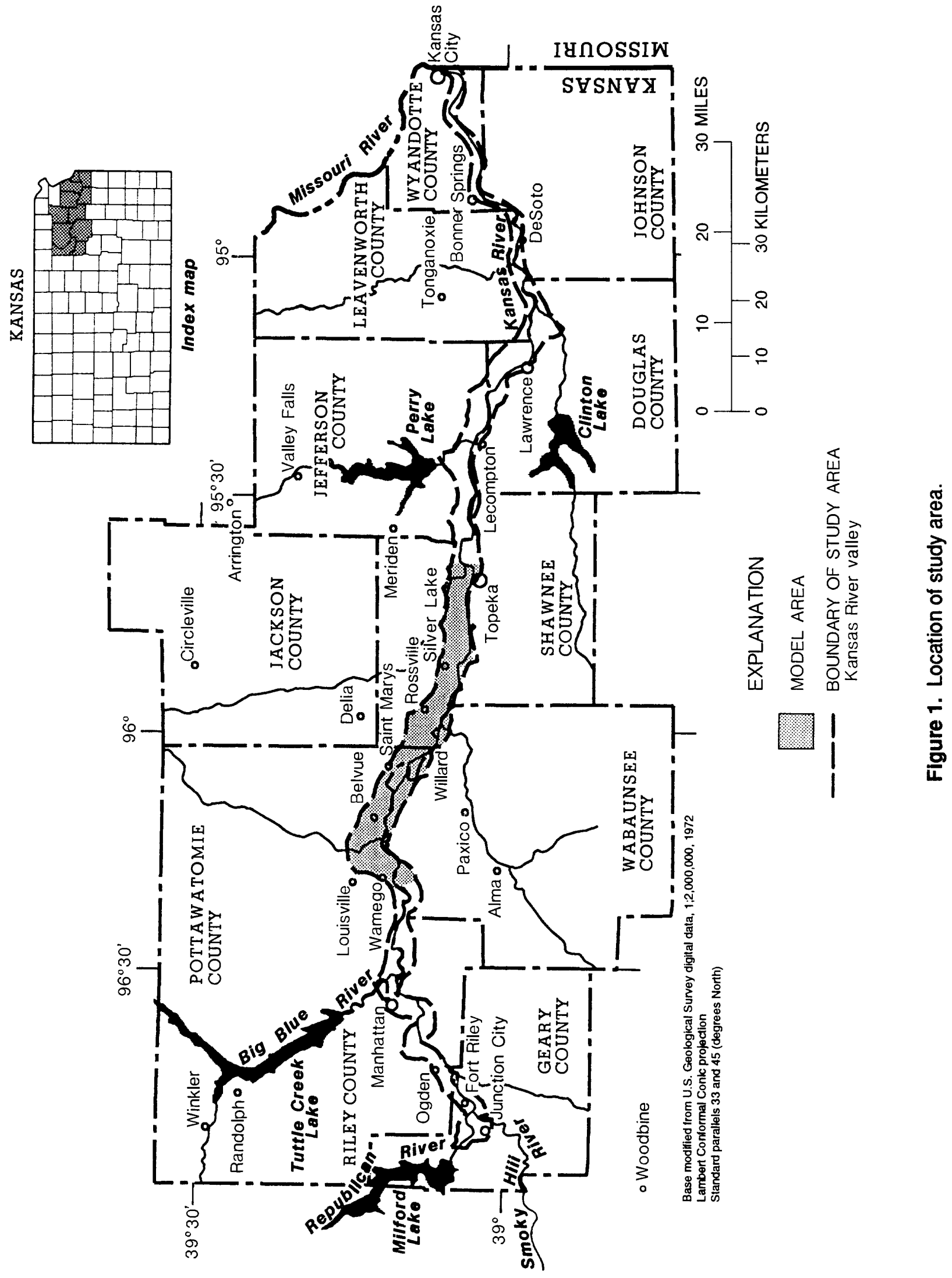




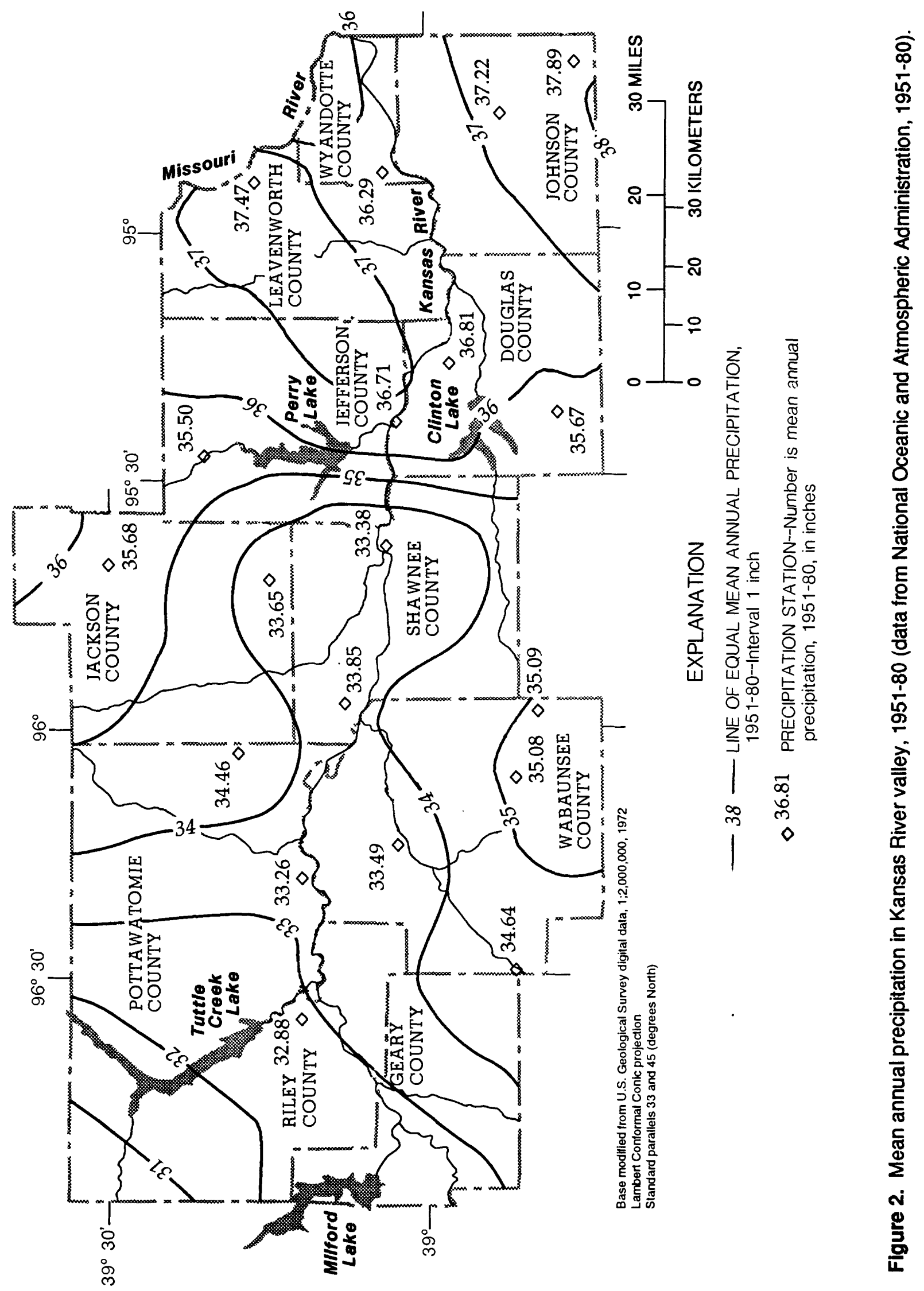




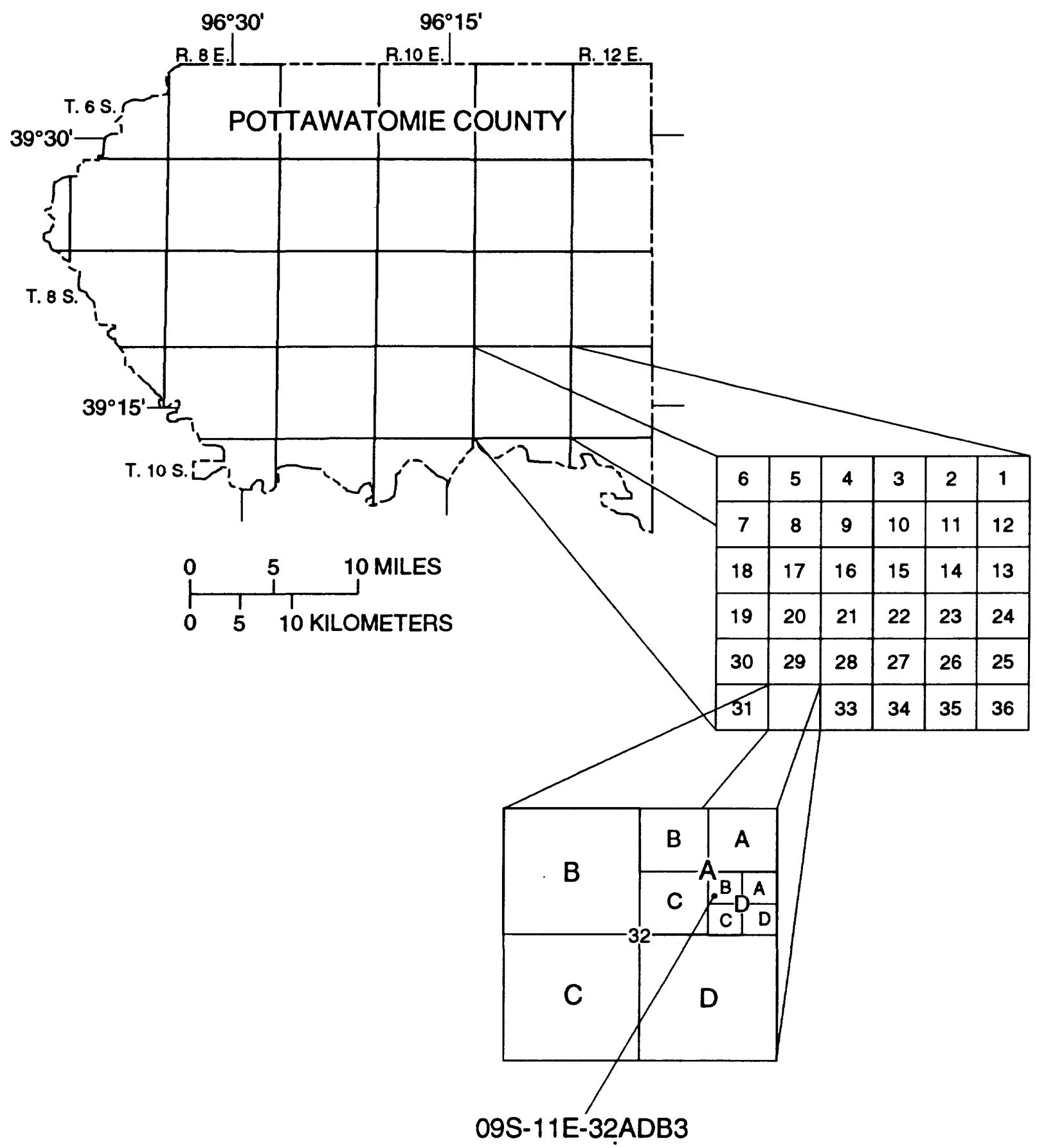

Figure 3. Well-numbering system. 
and the Division of Water Resources of the Kansas State Board of Agriculture in Topeka. The U.S. Bureau of Reclamation provided information from their "BASIN2" model (Otradovsky, 1986) of the Kansas River valley, including monthly precipitation, evapotranspiration, and crop-irrigation requirements, which was incorporated as part of the input data to the finite-element model used in this study.

\section{STREAM-AQUIFER SYSTEM}

The Kansas River and its associated valley-fill deposits act together as a single, integrated hydrologic system composed of various elements (fig. 4). The alluvial aquifer consists of relatively clean, well-sorted sand with some gravel and is bounded at the base and on the north and south by relatively impermeable bedrock, generally shale or limestone. The Kansas River, which normally is several hundred feet wide, partially penetrates valley-fill deposits. Water in the alluvial aquifer originates as recharge from downward percolation of precipitation, and secondarily of applied irrigation water, municipal-sewer leakage, septic-system infiltration, and occasionally streambed leakage. Ground water then generally flows horizontally down valley and toward the river, and upward where it discharges into the river. Thus, the river and those parts of its tributaries that lie within its flood plain or terraces generally act as a drain or line of discharge for flow from the aquifer, as evidenced by the gradient of the water table toward the river and its tributaries. This flow, or ground-water discharge, sustains base flow in the river and its tributaries during extended periods of little or no precipitation.

Streamflow generally is composed of two principal, but difficult-to-differentiate, components: (1) base flow (ground-water discharge) and (2) overland or storm runoff. When rainfall exceeds soil-moisture deficiency or when the rate of rainfall exceeds the rate of infiltration, overland runoff to the river channel and its tributaries occurs. If the stream level

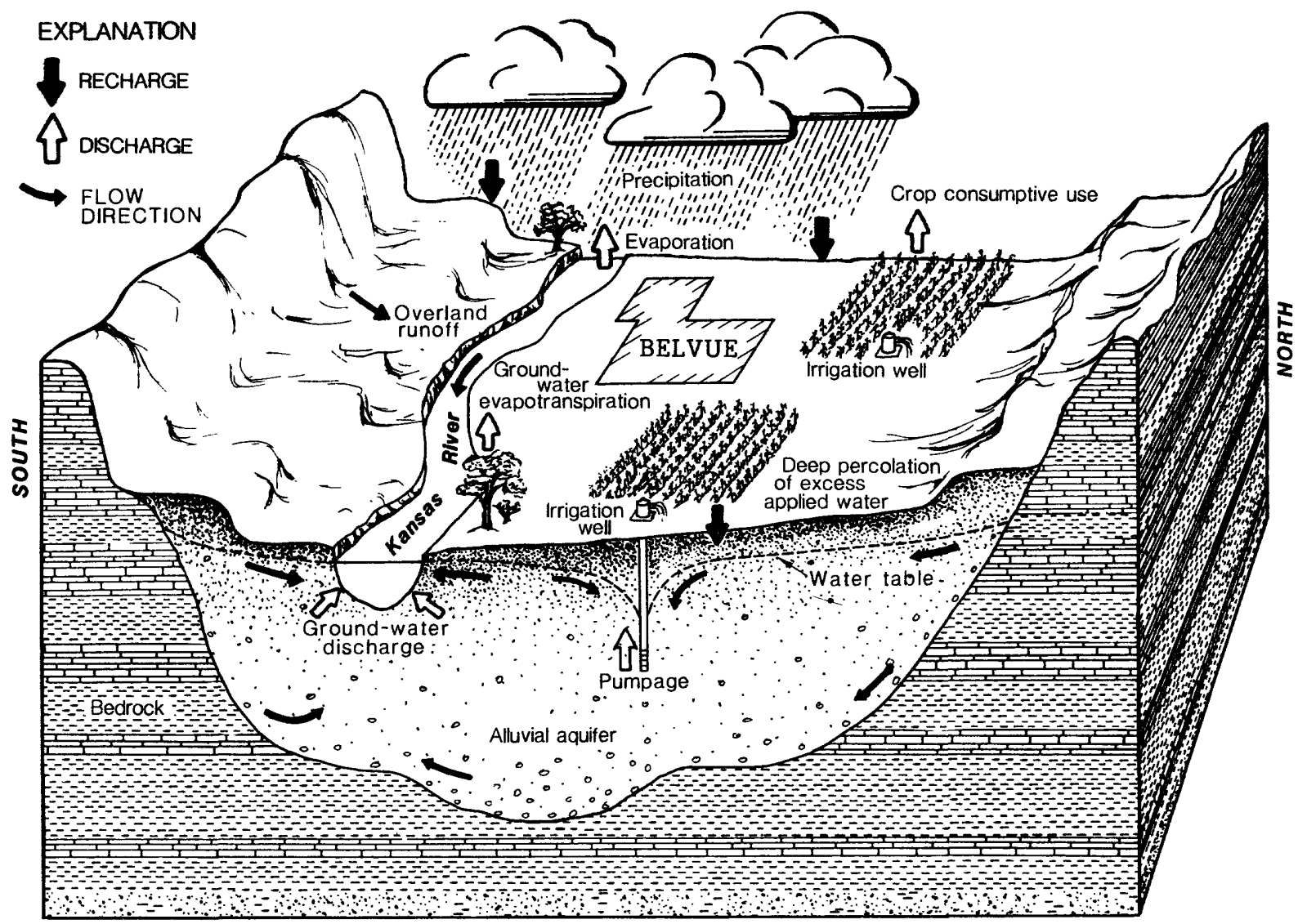

NOT TO SCALE

Figure 4. Generalized hydrologic cycle and flow directions in Kansas River valley. 
rises quickly, the normal flow of ground water toward the river is slowed temporarily and may even be reversed. If river stage exceeds the water level in the aquifer, the hydraulic gradient is reversed, stream water goes into bank storage, and surface water flows into the aquifer, as evidenced by a temporary trough in the water table parallel to the river (fig. 5). Generally this condition lasts only a few hours to several days until the river stage drops, the water-table gradient toward the river is reestablished, and ground water again discharges into the river.

\section{Ground Water}

Ground water in the Kansas River valley is under water-table (unconfined) conditions throughout the length of the study area. Thicknesses of the saturated zone in the alluvial material range from less than 1 foot at the valley edges to as much as 70 feet in the deepest part of the valley. Water levels generally are affected by the hydraulic conductivity and specific yield of the aquifer, recharge and discharge rates to and from the aquifer, location and type of hydrologic boundaries, and the volume of flow across these boundaries. Maps showing lines of equal water-table altitude are useful to determine the direction of ground-water flow and hydraulic-head gradients.

Water-table maps have been published for the entire study area for spring 1967 (Fader, 1974), for the Wamego-Topeka area for spring 1956 (Beck, 1959), and the Topeka area for 1950 (Winslow and Nuzman, 1966). In addition, a water-table map of the modeled area was prepared from a water-level mass measurement made for this study in February and March of 1987 (fig. 6). These maps are used to assess spatial differences in water levels in the aquifer at a particular point in time.

Water-level measurements were made periodically at various observation wells in the Kansas River valley and entered into the U.S. Geological Survey's Ground-Water Site Inventory (GWSI) data base. Retrievals of these water-level data for the Kansas River valley indicate that there are more than 1,000 sites with one-time only measurements and 230 sites with multiple measurements. Of the 230 multiple-measurement sites, there are 43 with 4 years or more of record in the Wamego-Topeka modeled area (fig. 7). These measurements, when plotted as ground-water hydrographs, are useful to assess temporal differences in water levels during their period of record at a particular point in space in the aquifer.

Inspection of the 43 multiple-measurement hydrographs indicate that since the early 1950's water levels have fluctuated cyclically in response to cyclical patterns of precipitation. In addition, there do not appear to be substantial long-term declining water-level trends, which indicates that recharge to the alluvial aquifer approximates discharge from the aquifer, including well withdrawals. Figure 8 is an example hydrograph showing little long-term net change in water level. However, locally there are some relatively persistent cones of depression around industrial and municipal wells and some seasonal cones of depression around irrigation wells in the Wamego-Topeka area. Water levels in or adjacent to the industrial and municipal wells fluctuate seasonally or even daily in direct response to withdrawals.

In order to observe water-level and hydraulic-gradient responses to seasonal irrigation-well pumpage, a lineal series of six observation wells was installed in June 1988 from the bank of the Kansas River across from Willard north about 2 miles along the county road between the Willard bridge and Rossville (fig. 5, B-B'). The stage in the Kansas River beneath the Willard bridge and water levels in the observation wells were measured weekly by the Kansas Water Office (Topeka) during the irrigation seasons (summers) of 1988 and 1989. Water-level measurements indicate that irrigation-well pumpage in the area of the observation wells has not reversed the gradient of the water table so as to induce infiltration of water from the river, even during the 1988-89 drought. Although the slope of the water-level profile described by the line of observation wells decreases or increases at times (fig. 5, B-B'), the gradient is always toward the river, except adjacent to the river during abrupt rises in river stage (as on September 8, 1989). 

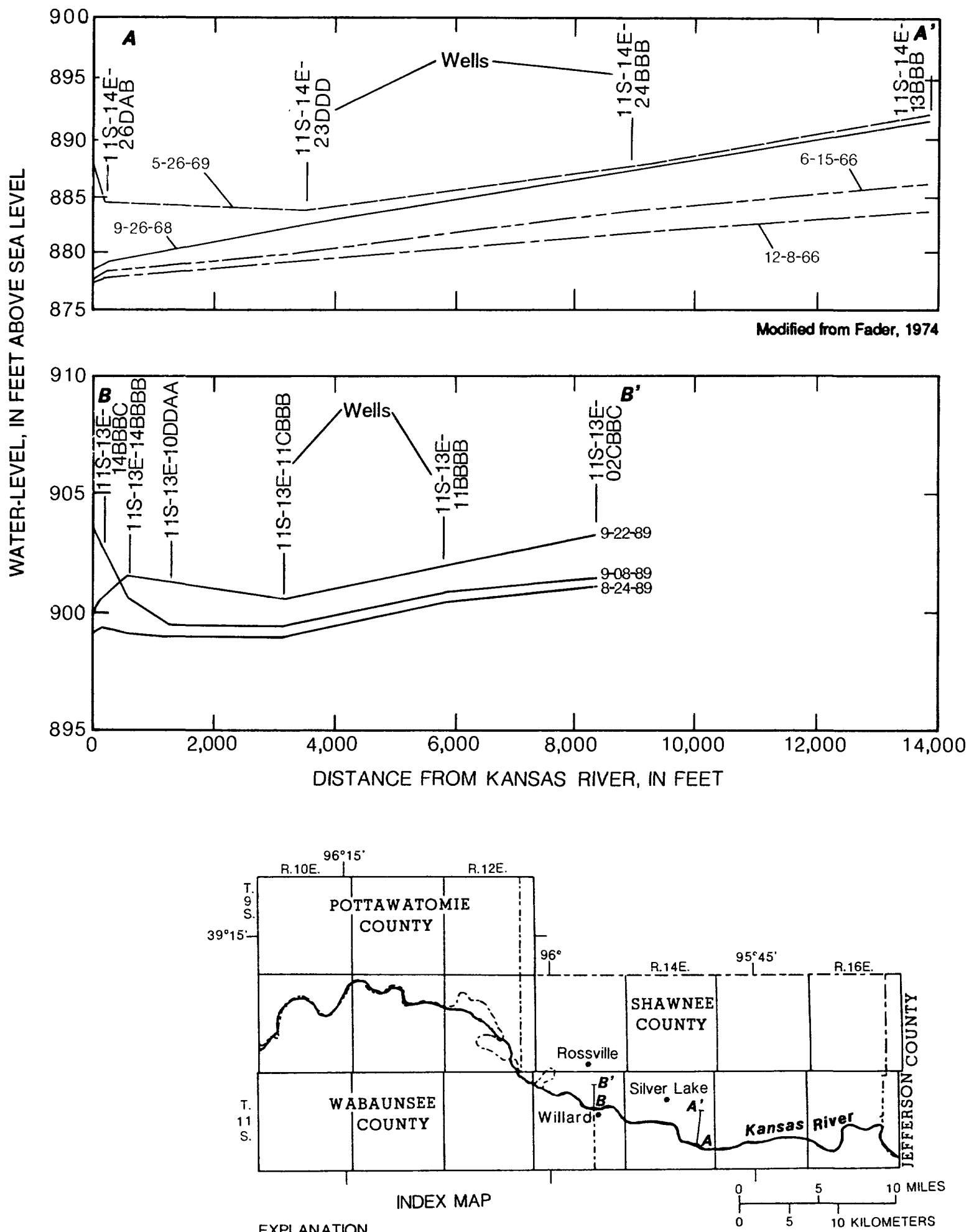

EXPLANATION

$A \longrightarrow A^{\prime}$ TRACE OF WATER-LeVEl PROFILE

Figure 5. Water-level profiles in the alluvial aquifer adjacent to Kansas River. 


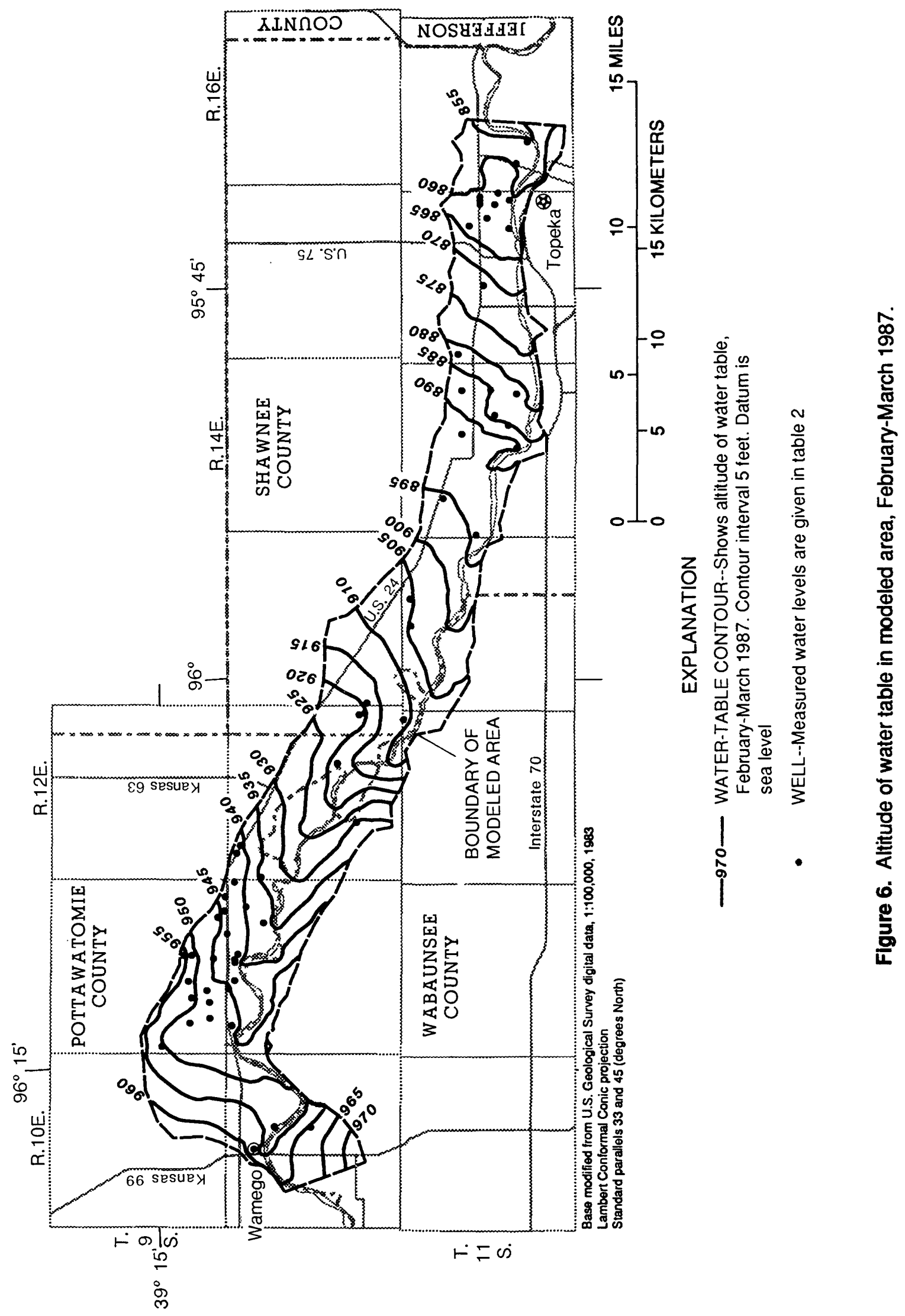




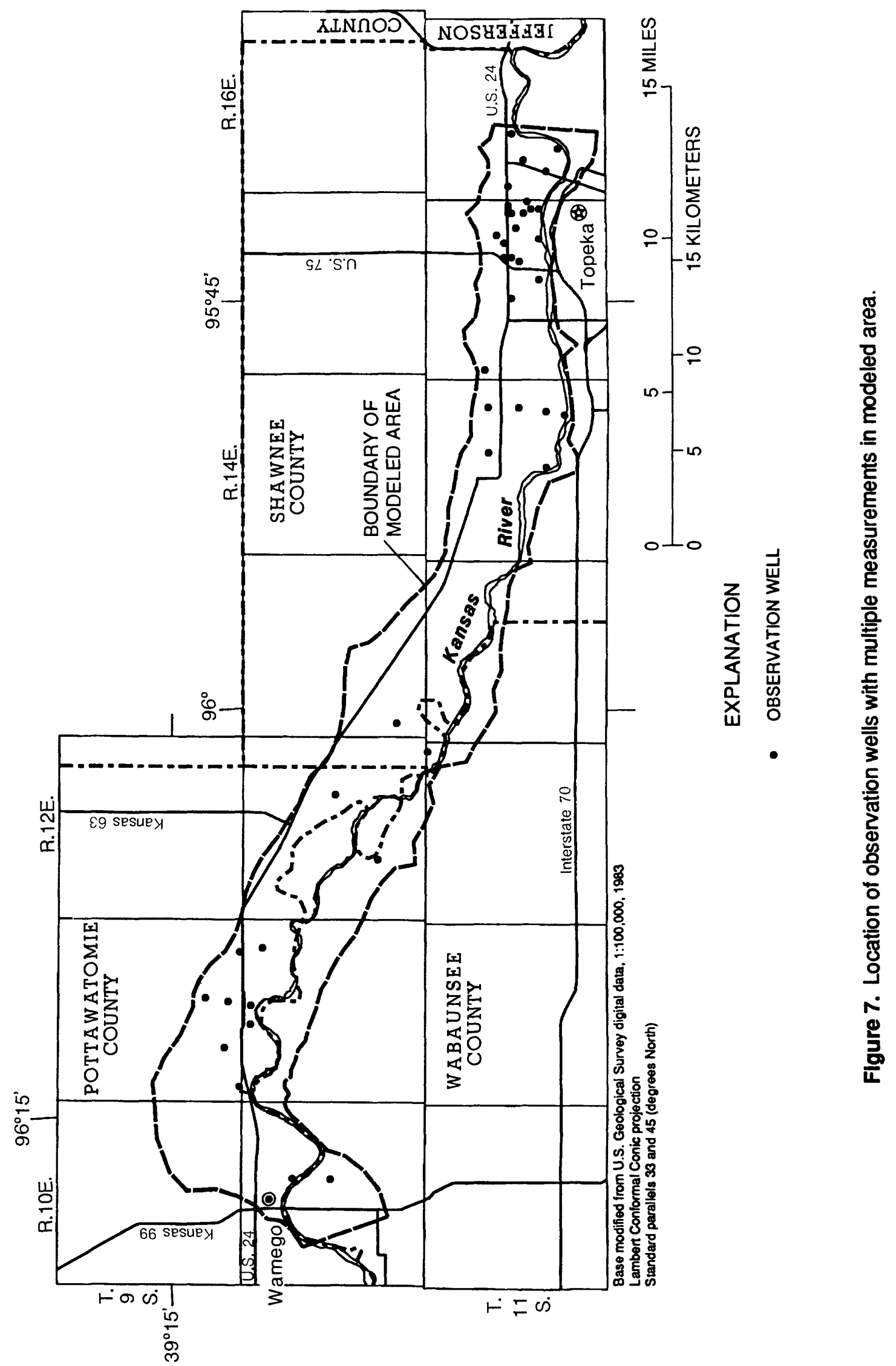




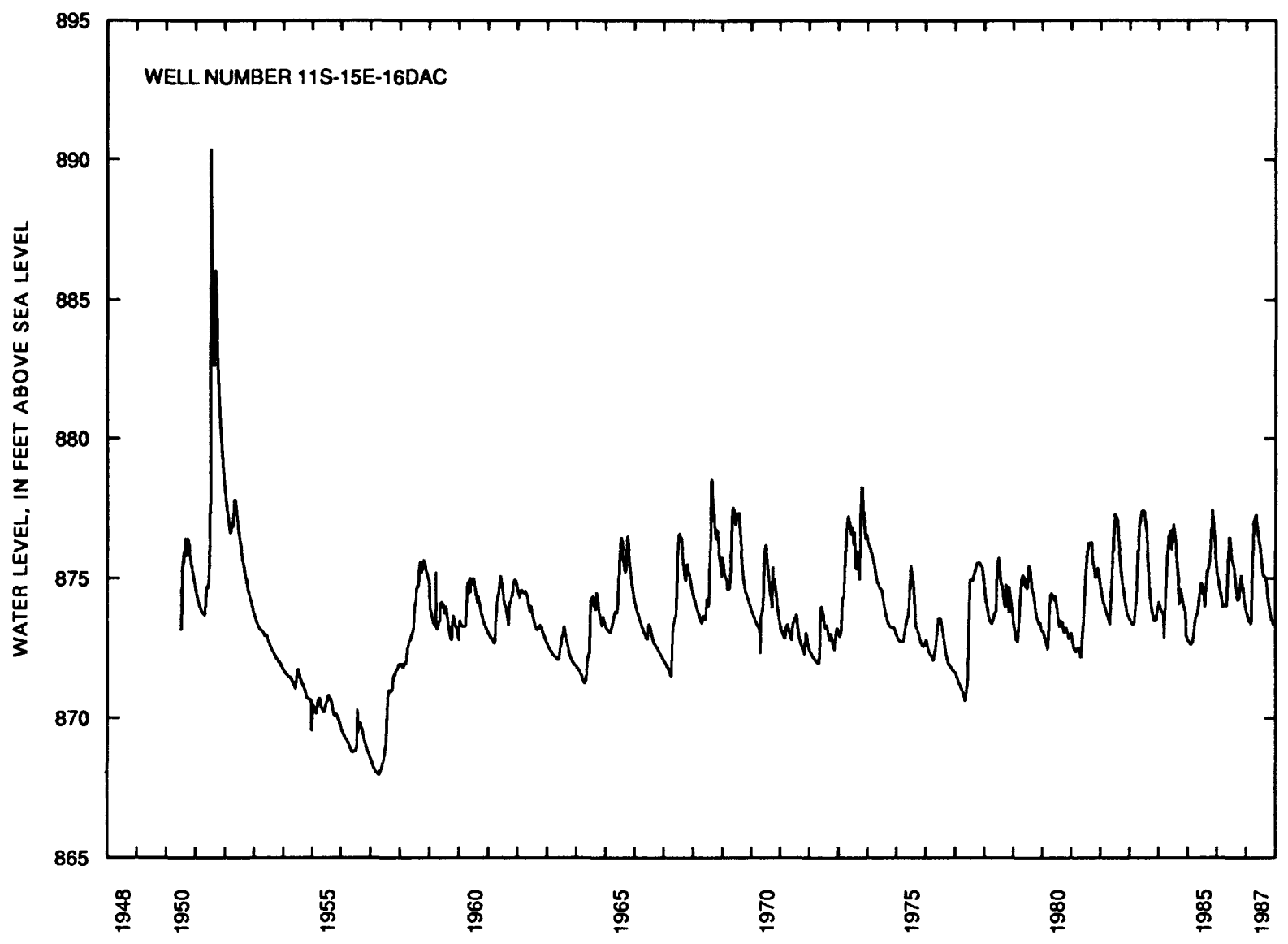

Figure 8. Example hydrograph of measured water level, 1950-87.

\section{Surface Water}

After the disastrous 1951 flood on the Kansas River (U.S. Geological Survey, 1952), the U.S. Army Corps of Engineers built a series of dams and reservoirs mainly for flood protection but also for other multipurpose uses, such as water supply for municipal, wildlife, and recreational use. Four of these reservoirs on tributaries close to the main stem Kansas River are Milford, Tuttle Creek, Perry, and Clinton Lakes (fig. 1). Retention of streamflow in or release of water from these reservoirs, as well as from upstream tributary reservoirs, modified the natural flow conditions of the Kansas River so as to prevent flood flows and to assure minimum flows.

The U.S. Geological Survey operates active continuous-record streamflow-gaging stations along the Kansas River at or near Fort Riley, Wamego, Belvue, Topeka, Lecompton, and DeSoto. Discontinued stations were located at Ogden and Bonner Springs. Stage-only stations are located at Manhattan and Kansas City, Kansas. Gaging stations also are or were maintained on many of the tributaries to the Kansas River. The location of the streamflow-gaging stations is shown in figure 9. Information relevant to these stations is listed in table 1.

\section{MATHEMATICAL} REPRESENTATION OF STREAM-AQUIFER SYSTEM

The use of digital computers to simulate hydrologic processes has increased substantially in recent years because the computer can rapidly and inexpensively solve the repetitive sets of mathematical equations that account for the hydrologic conditions of a particular area. Computer models are used extensively to simulate ground-water flow in the evaluation and management of water in aquifers, but only a few of these models also account for surface-water flow in associated streams. 


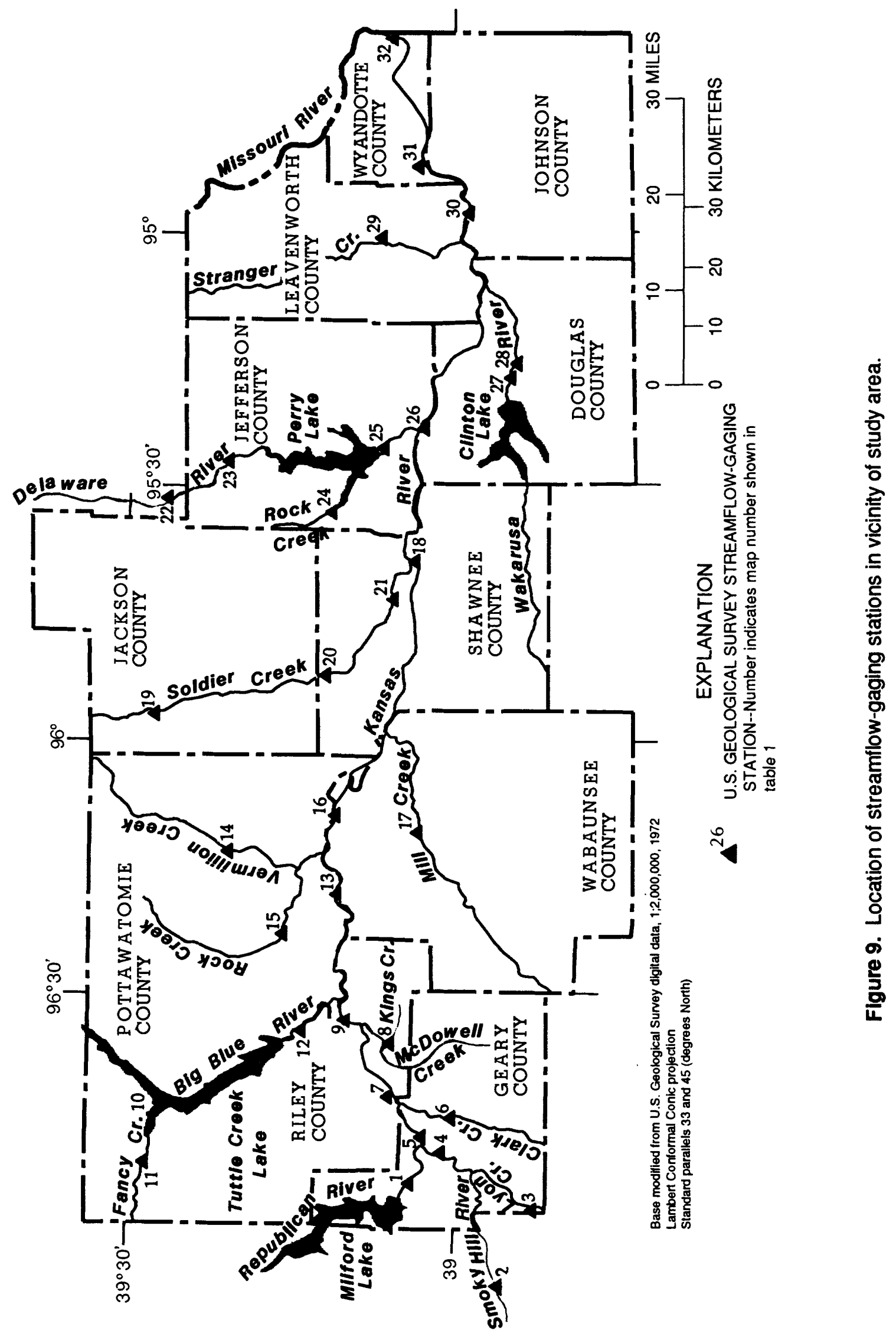




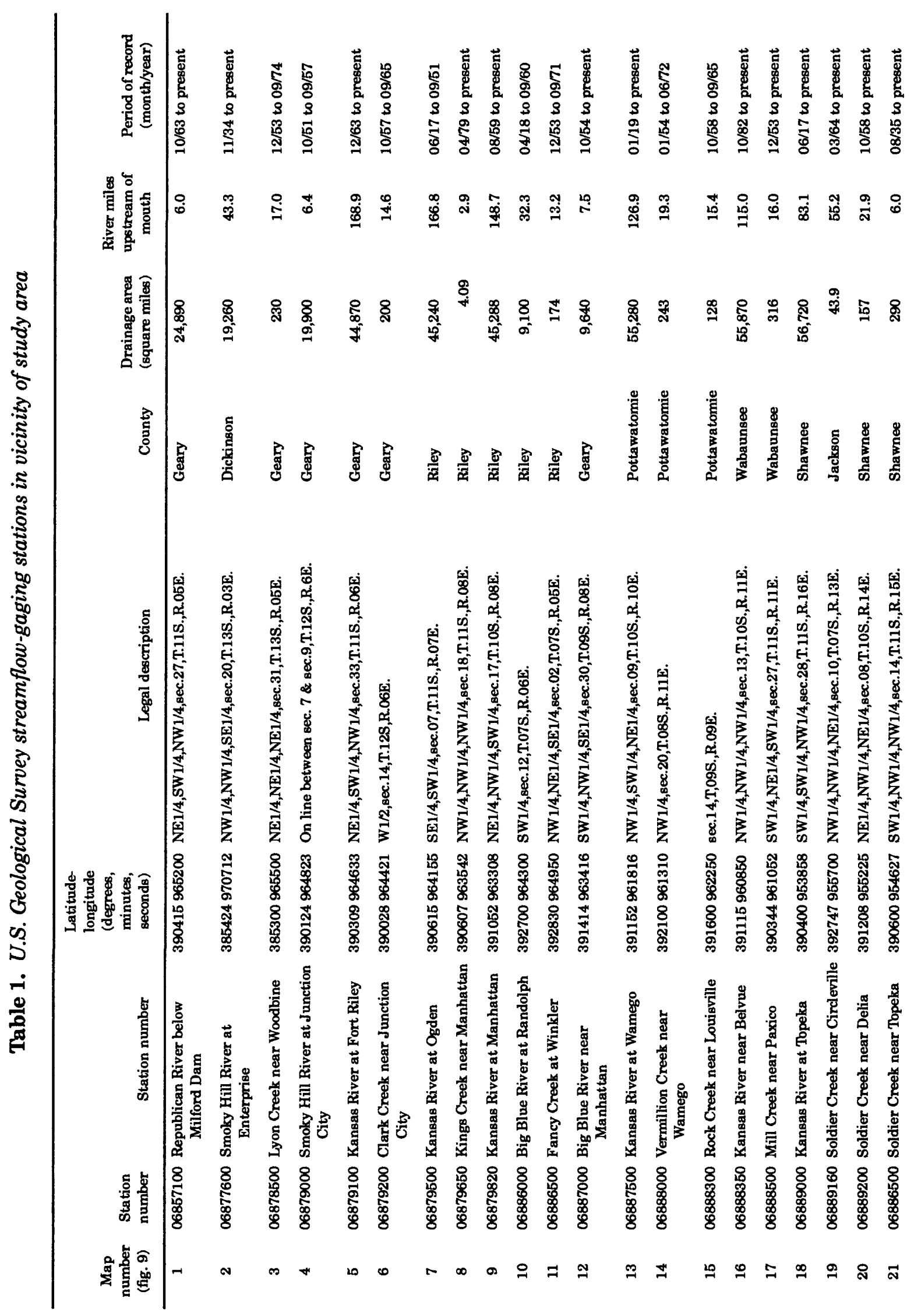




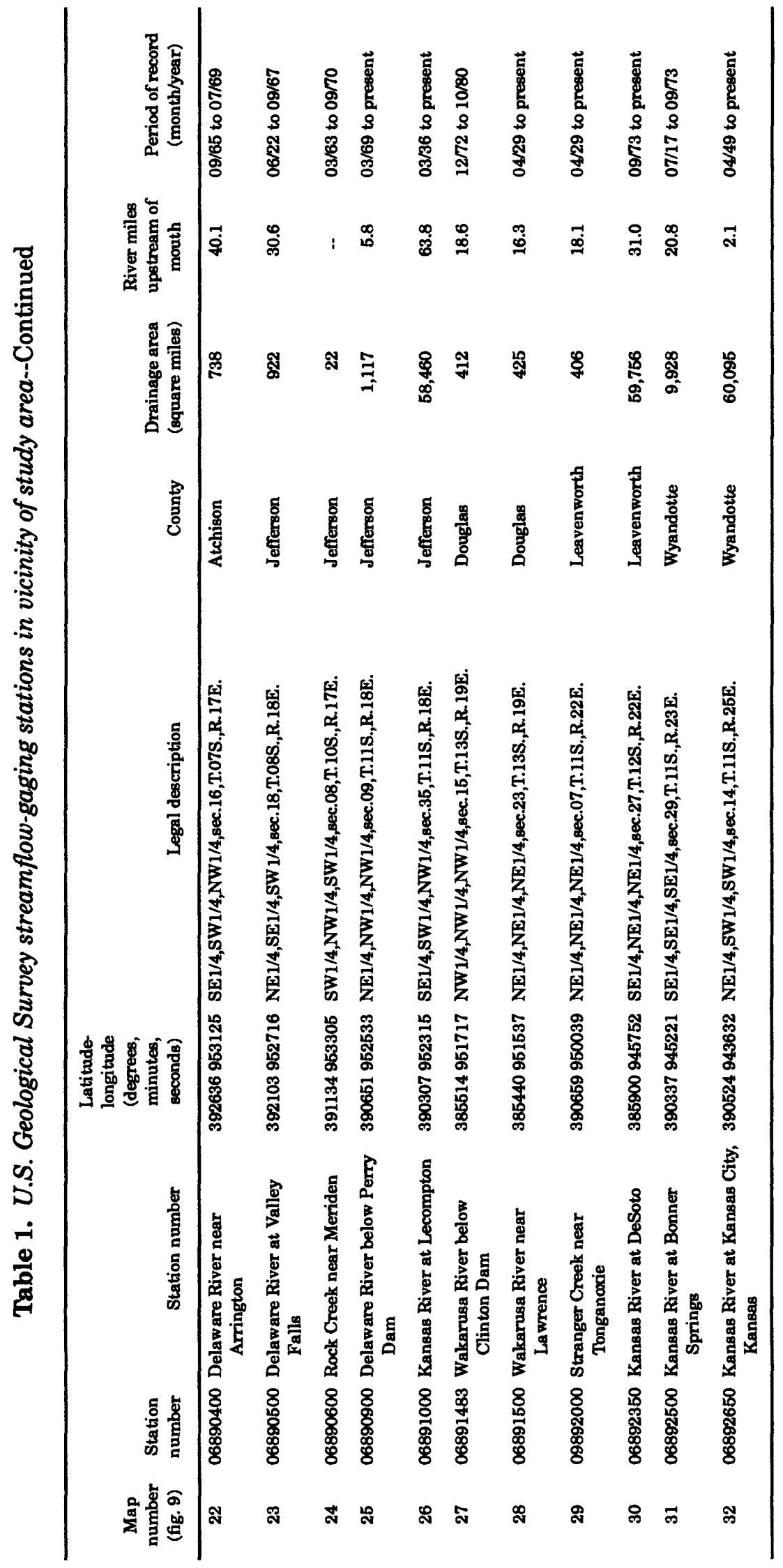




\section{Digital Model Description and Construction}

The computer model used for the Kansas River valley stream-aquifer system is a program written in FORTRAN code, which solves equations of ground-water flow, accounts for the volume of surface-water flow in the stream, and simulates the interaction between water in the stream and ground water. The program is a two-dimensional, finite-element model, written by J.V. Tracy and documented and modified by others of the U.S. Geological Survey (Dunlap and others, 1984; Wexler and Maus, 1988). Some simplifying assumptions necessary for the use of this model are that flow in the aquifer is horizontal, the aquifer is underlain by an impermeable boundary, and flow across the stream-aquifer boundary is vertical.

The finite-element model used here was chosen from the various models available because it offered the best combination of features necessary to achieve the study objectives. Compared to other methods, the finite-element technique has more flexibility in design of the model grid and allows a better simulation of the boundary conditions with the stream-aquifer interface and the limits of the relatively narrow alluvial aquifer along the bedrock valley walls. The model accounts for transient conditions of streamflow for large-scale stream-aquifer simulation, and it provides an itemized stream-aquifer water budget. The surface-water routing routine is not a true surface-water flow model but rather is an accounting program that tracks the flow in the stream as it interacts with the aquifer in a progressive, node-by-node manner from upstream to downstream.

The finite-element model is based on the Galerkin (weighted-residual) method described by Desai and Abel (1972) and uses the CSR (Cholesky square-root) computional method described by Weaver (1967) to solve the nonlinear, partial-differential equations describing nonsteady, two-dimensional ground-water flow. A direct solution to the sets of simultaneous equations that result from the finite-element formulation is provided by the CSR method. The model produces an approximate solution to the partial-differential ground-water flow equation:

$$
\frac{\partial}{\partial x}\left(K b \frac{\partial}{\partial x}\right)+\frac{\partial}{\partial y}\left(K b \frac{\partial h}{\partial y}\right)=s \frac{\partial h}{\partial t}+W,
$$

where

$x$ and $y$ are the coordinate axes [L];

$K=$ hydraulic conductivity of the aquifer $\left[\mathrm{LT}^{-1}\right]$;

$b=$ thickness of saturated zone $[\mathrm{L}]$;

$h=$ hydraulic head [L];

$S=$ storage coefficient (dimensionless);

$t=$ time $[\mathrm{T}] ;$ and

$W=\mathrm{W}(x, y, t)$ is the net vertical flux into (or out of) the aquifer from point or distributed sources (or sinks), such as wells, evapotranspiration, ground-water percolation, or river-aquifer interaction $\left[\mathrm{LT}^{-1}\right]$.

The computer model does not solve the flow equation directly but instead uses a numerical technique to approximate the equation in an iterative fashion for one finite part of the hydrologic system at a time. The model area is divided into smaller triangular areas defined by the position of their corners, which are called nodes. The triangular areas between nodes are referred to as elements. Nodes are positioned to best represent the stream-aquifer system. The system can be defined by systematically numbering nodes and elements. The finiteelement grid controls the numerical solution of the flow equation.

The model grid for the Wamego-Topeka reach of the Kansas River stream-aquifer system, shown in figure 10, was constructed so that the elements cover the irregularly shaped areas of the modeled stream-aquifer system as completely as possible. The grid is a twodimensional system of nodes numbering 7 (south to north) by 76 (west to east) for a total of 532 nodes. There are 900 elements generated by this arrangement.

At each node, values of hydraulic conductivity, specific yield, and altitudes of the base of the aquifer, land surface, and water table were specified. Additional interior special- 


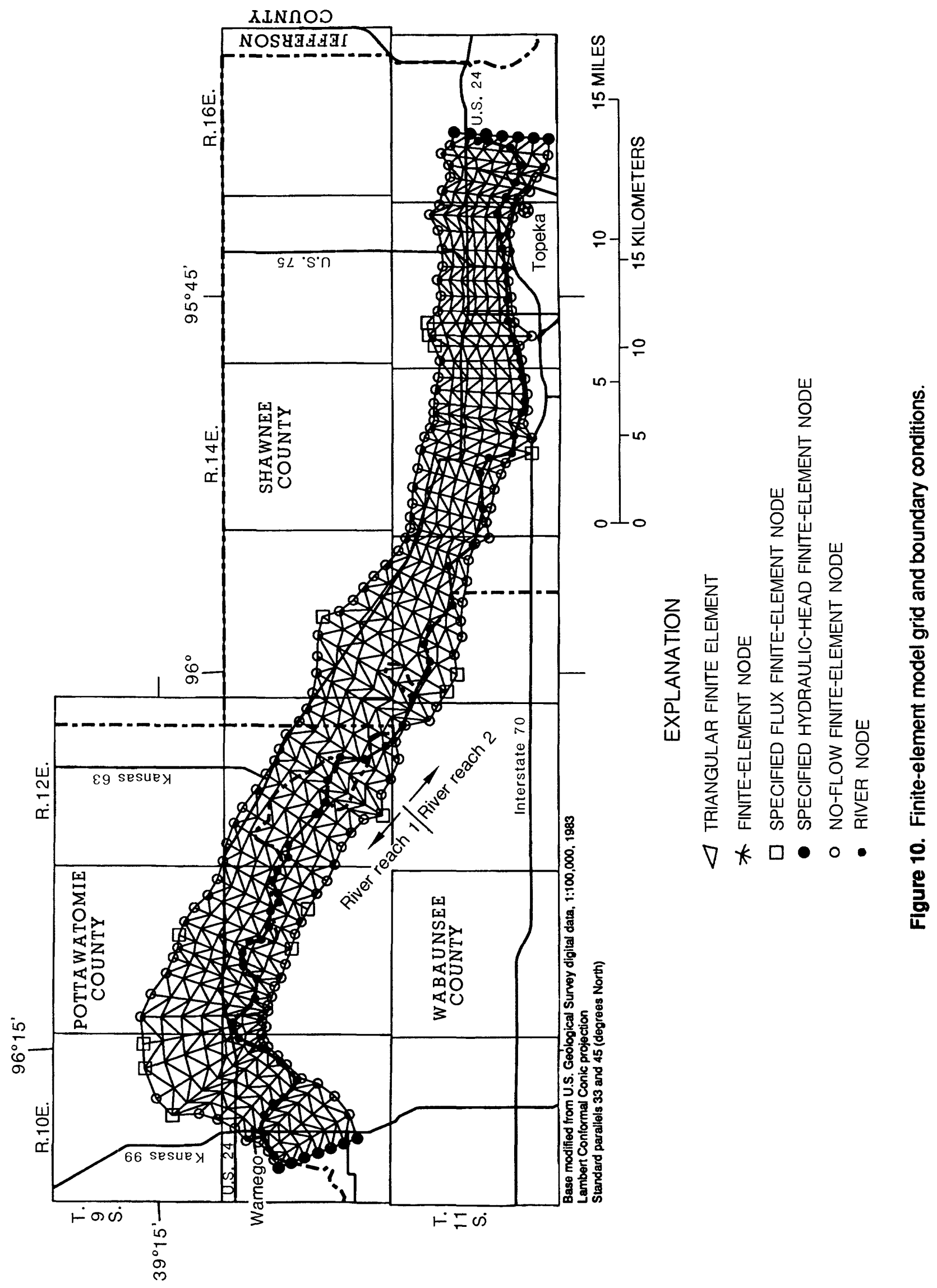


purpose nodes were superimposed on the grid to simulate stream-aquifer interaction, discharge from large-capacity wells, and aquifer discharge to tributary streams. For the stream-aquifer interaction, 60 river nodes were used to route streamflow and provide for the simulation of stream-aquifer interconnection. The nodes generally are located where the river bends, but some are placed along long straight segments of the stream. Interior nodes used to simulate withdrawal from large-capacity wells generally increased in number for each year of the calibration period from 43 in 1948 to 433 in 1987. The model allows direct simulation of stream-aquifer interaction only on the main-stem river. Tributary inflow is simulated at those river nodes representing the mouth of each tributary. Aquifer discharge to tributary streams was simulated by use of 110 pumped wells placed along the routes of the larger tributaries.

In the same manner that space needs to be divided to permit numerical approximation of the flow equation, simulation of transient conditions requires that time be divided into finite intervals, called time steps. To provide sufficient detail of simulated conditions and to minimize truncation error, a sequence of 5-day time steps was used for most transient analyses.

\section{Boundary Conditions}

For the model to solve the ground-water flow equation, either the hydraulic flux or the hydraulic head must be specified at each boundary node. Boundary conditions are specified in the model to represent appropriate ground-water flow at the edges of the aquifer system. This was achieved on the western and eastern boundaries by using specified hydraulichead nodes to simulate lateral inflow at the upstream end and lateral outflow at the downstream end that occur due to the gradient across the area (fig. 10). Appropriate monthly proportional modifiers are applied to the specified-head nodes to agree with recorded water-level fluctuations in a representative long-term observation well, thereby simulating appropriate temporal changes in hydraulic head. No-flow nodes were used along most of the north and south bluffs of the valley to simulate the effect of lateral termination of the alluvial aquifer at the relatively impermeable bedrock boundaries. However, selected specified flux nodes were used to simulate lateral ground-water inflow in areas where tributary valleys intercept model boundaries along the valley walls. The rate of flux, $Q$, along a boundary segment, was estimated from Darcy's equation:

$$
Q=K A\left(\frac{d h}{d l}\right)
$$

where

$K=$ hydraulic conductivity of the aquifer $\left[\mathrm{LT}^{-1}\right]$;

$A=$ cross-sectional area of flow $\left[\mathrm{L}^{2}\right]$; and $\frac{d h}{d l}=$ hydraulic gradient [dimensionless].

\section{Input of Aquifer Data to Model}

\section{Hydraulic Properties}

The model multiplies hydraulic conductivity, a measure of the aquifer's ability to transmit water, times thickness of saturated zone to compute the required transmissivity distribution during simulation. Transmissivity changes as water levels change, but hydraulic conductivity was assumed to be constant through time.

On the basis of 18 aquifer tests in the entire Kansas River valley alluvium (Fader, 1974, p. 8), hydraulic conductivity ranged from about 200 to 960 feet per day and averaged 675 feet per day. Four of the 18 aquifer tests, located in the Wamego-Topeka model area, had an average hydraulic conductivity of 765 feet per day. On the basis of these results, the hydraulic conductivity was varied throughout a reasonable range during model calibration, although it was kept areally uniform. Although areal variability in hydraulic conductivity exists in the alluvium, no attempt was made to define the variability because of insufficient data and because it was determined that simulation results are relatively insensitive to variations in hydraulic conductivity.

Specific yield determines the magnitude of water-level changes that occur as a result of ground-water recharge or discharge. The rise or decline of water levels per unit volume of water 
injected into or removed from the aquifer is proportional to the specific yield. The value of the specific yield is related to the porosity and degree of sorting of the sand-and-gravel alluvial aquifer; the greater the porosity and the better the sorting, the greater the specific yield. Typical values for specific yield of an alluvial aquifer range from about 0.1 to 0.25 . Fader $(1974$, p. 8$)$ estimated an average specific yield of 0.15 on the basis of 18 aquifer tests in the Kansas River valley alluvium. This information provided the basis for varying specific yield during calibration.

\section{Recharge}

Most recharge to the ground-water system occurs as water infiltrates the land surface and percolates through the unsaturated zone to the water table. Sources of water that may percolate to the water table are precipitation and applied irrigation water (from either well pumpage or surface-water diversion). These sources can be called applied water because they are applied to the land surface. The model uses an algorithm developed by the U.S. Department of Agriculture (1967) to divide applied water between evapotranspiration (evaporation of soil water and transpiration by plants) and deep percolation. The model does not account for overland runoff and, therefore, may overestimate the deep-percolation part of applied water. However, the amount of overland runoff in the Kansas River valley is considered minimal because the soils are sandy and the topography is flat. Therefore, this approach is believed not to have affected substantially the calibration of the Kansas River valley model nor is it considered a problem when making long-term simulations of hypothetical conditions.

The relative volume of applied water that is modeled as going to either evapotranspiration or deep percolation depends on the rate of application of water, the rate of potential evapotranspiration (evapotranspiration demand), and the moisture capacity of the soil zone. For a given rate of application of water, the greater the rate of potential evapotranspiration or the larger the moisture capacity, then the greater the rate of evapotranspiration and the smaller the rate of deep percolation.
Applied water is simulated by the model as the sum of well pumpage applied to the land, surface-water diversion for irrigation, and precipitation. Well pumpage for irrigation is applied to specific elements of the finite-element grid that are associated with the irrigated acreage of each well. Surface-water diversion for irrigation also is applied to specific elements of the finite-element grid associated with the irrigated acreage supplied by such diversions. Monthly precipitation rates, based on averages of stations in the area, are applied in the model equally to all elements of the finite-element grid.

Small rates of recharge to the aquifer also occur in ways other than direct percolation from the land surface. Subsurface lateral inflow in the main valley and in tributary valleys was described previously in the "Boundary Conditions" section. Some aquifer recharge occurs from infiltration through streambeds; however, most stream-aquifer interchange is discharge from the aquifer, and it is discussed in the "Discharge" section.

\section{Discharge}

The major discharges from the aquifer are pumping, discharge to streams, and evapotranspiration. A relatively minor rate of discharge occurs as subsurface lateral outflow, discussed in the "Boundary Conditions" section.

\section{Pumpage}

Pumpage from the aquifer was estimated on the basis of several procedures. Well-permit data were obtained from the Kansas State Board of Agriculture, Division of Water Resources (Topeka), and divided into type of water usage for each year. These data included information on well location, owner, date of application, appropriation rates and volumes, type of usage, number of acres irrigated, and so forth. The number of well permits for large-capacity wells in the Wamego-Topeka area was relatively small and remained relatively constant until 1952 when the number of well permits for irrigation began a steady increase (with substantial increases in the mid-50's and mid-70's) as compared to the number of permits for industrial or public-supply wells (fig. 11). 


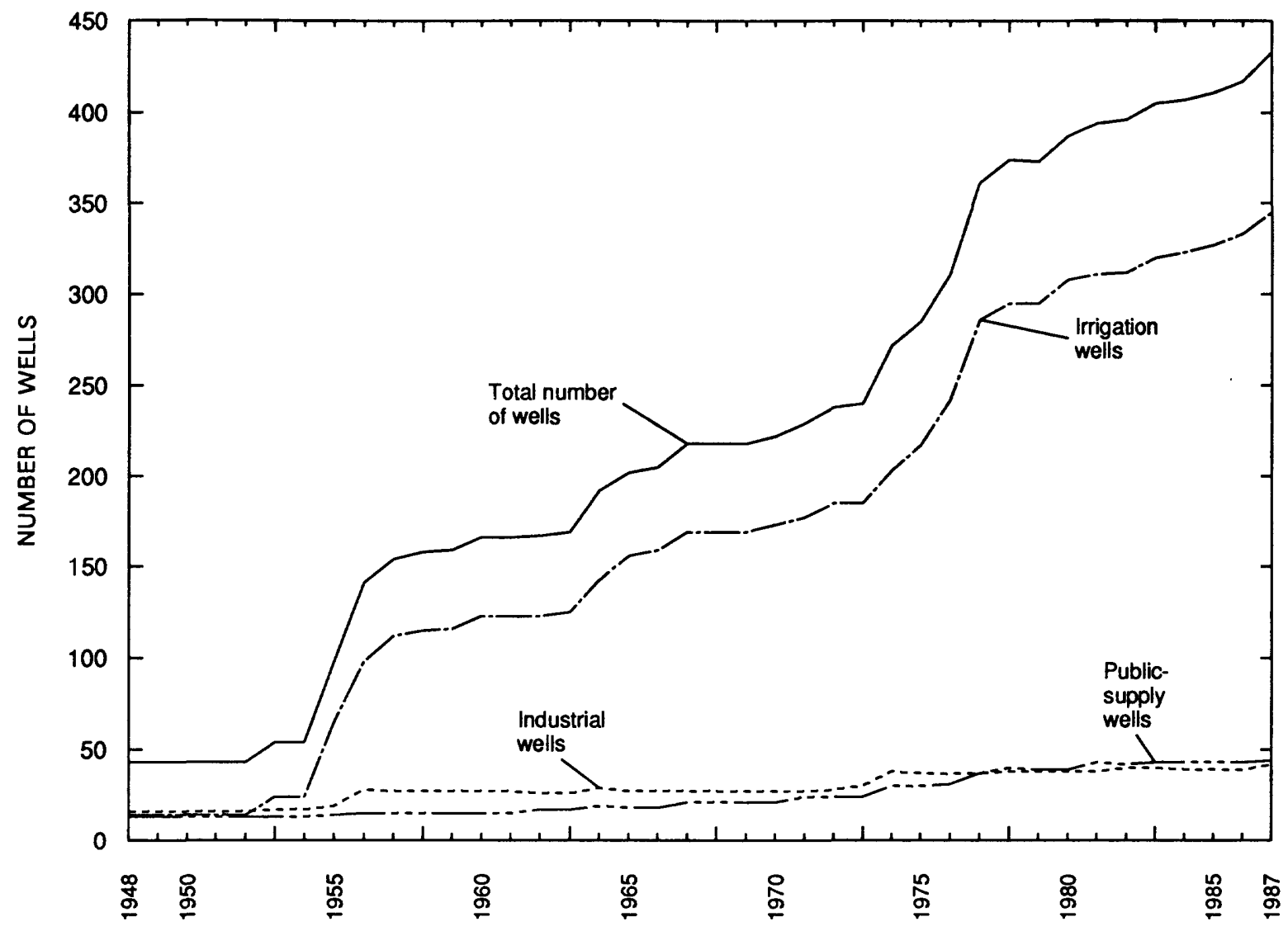

Figure 11. Number of permits for large-capacity wells in modeled area, 1948-87 (from files of the Kansas State Board of Agriculture, Topeka).

Reported pumpage was available from the Division of Water Resources on magnetic tape only back to the early 1980's. Available data from the Kansas Water Office show that municipal and, to some extent, industrial withdrawals increase during the summer months. Average monthly proportions from more recent years were extended back to earlier years. To estimate irrigation-well pumpage, monthly crop-irrigation requirements (in acre-feet), obtained from the U.S. Bureau of Reclamation's BASIN2 model (Otradovsky, 1986) for 1948-87, were multiplied by the number of acres irrigated by each well. The crop-irrigation requirements accounted collectively for the various crops grown in the Kansas River valley, although not distributively. The location of pumped wells in 1987, by type, is shown in figure 12; pumpage is simulated in a pattern represented by these well locations.

\section{Stream-Aquifer Interchange}

Water passes between the alluvial aquifer and the Kansas River through the streambed.
This stream-aquifer interchange can be either a source of recharge to or discharge from the aquifer but usually occurs as discharge. Values for streambed leakance (ratio of vertical hydraulic conductivity of the streambed to the thickness of the streambed) are not available or easily determined. Therefore, streambed leakance was varied throughout several orders of magnitude during model calibration.

The model simulates stream-aquifer interchange and orients the routing of streamflow along the Kansas River by use of the 60 river nodes shown in figure 10 . As part of the model input, streambed altitude, lengths, and widths are specified for each river node. Lengths and widths were determined from U.S. Geological Survey 7 1/2-minute topographic maps; streambed altitudes were interpolated between known values at gaging stations, including periodic adjustments to account for stream downcutting. Thirteen of the 60 river nodes are shown in figure 13 and represent surface-water inflow of the main stem at the upstream end as well as inflow from 12 


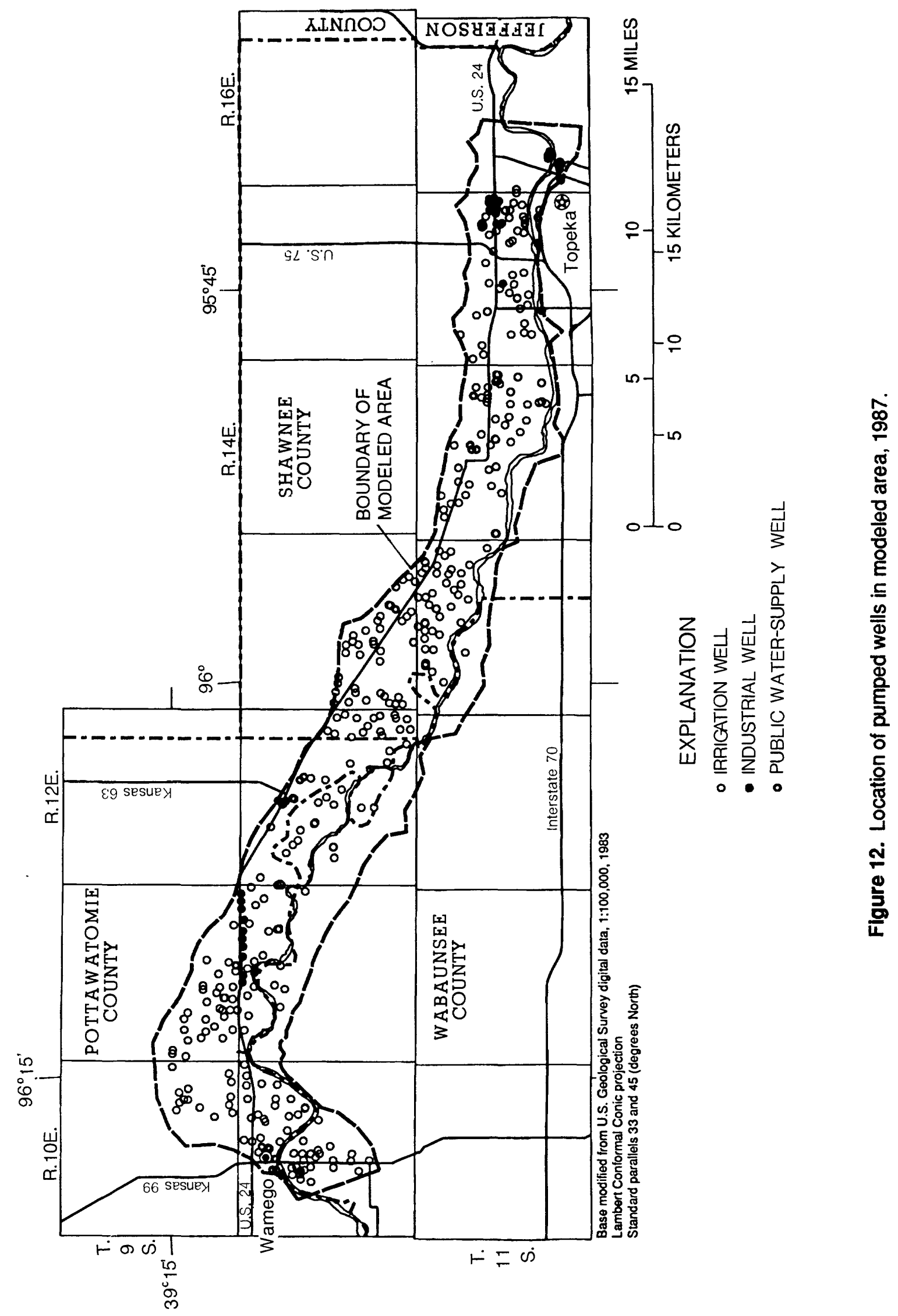




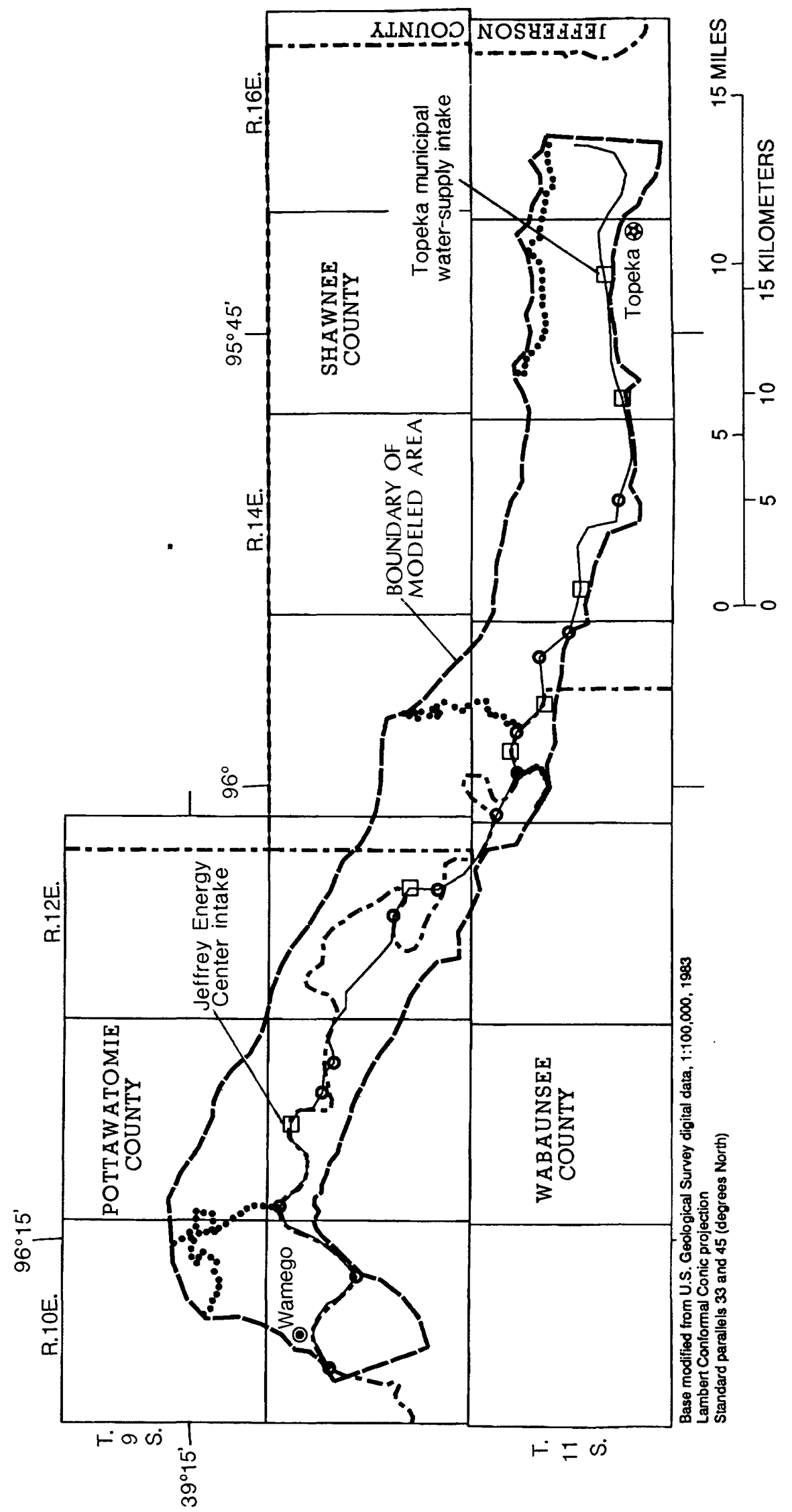

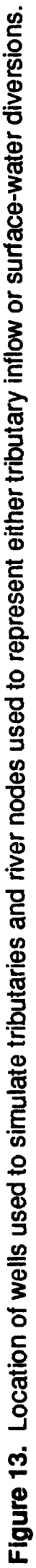


tributaries to the Kansas River. Daily-discharge values were assigned at the uppermost river node to represent the discharge recorded by the U.S. Geological Survey streamflow-gaging station at Wamego (fig. 9, map number 13) for 1948-87. One gaged tributary, Mill Creek, was assigned daily values recorded at the gaging station near Paxico (fig. 9, map number 17) and adjusted for the additional drainage area between the gaging station and the mouth of the creek. The other 11 inflow river nodes, representing ungaged tributaries, were assigned discharge values calculated by first averaging daily discharges for two nearby gaged tributaries, Mill Creek near Paxico and Soldier Creek near Topeka (fig. 9, map numbers 17 and 21). The average daily discharge values then were divided by the total drainage area of the two stream basins to give an average daily runoff value per square mile of drainage area. This daily runoff value was applied to each of the 11 larger tributary streams that enter the Kansas River in the modeled area by multiplying each drainage area by the computed daily runoff per square mile (the effects of factors such as geology and slope are considered similar among the drainage areas). Discharge values were computed for each of the tributary-inflow river nodes for each day of the 40-year simulation period from 1948 through 1987. Additionally, 7 other river nodes, shown in figure 13, include negative tributary-inflow values that represent surface-water diversions for irrigation, the Kansas Power and Light Jeffrey Energy Center, and the Topeka municipal water-supply plant.

The model simulates streamflow for all river nodes in a progressive upstream-to-downstream fashion. Starting with initial streamflow conditions represented by the gaged daily flow at Wamego and working downstream, for each time step the flow is calculated for each river node on the basis of: (1) incoming flow from the upstream node, (2) the gain from, or loss to, the aquifer over the area of the river node (stream-aquifer leakage), and (3) at the appropriate river nodes, the increase from tributary inflow or the decrease by surfacewater diversions.

The stream-aquifer leakage between the Kansas River and the alluvial aquifer occurs through the streambed and is simulated in the model according to:

$$
\begin{gathered}
Q=\frac{k^{\prime}}{b^{\prime}}\left(h_{s}-h_{a}\right) A, h_{a}>h_{s b} \\
\text { or } \\
Q=\frac{k^{\prime}}{b^{\prime}}\left(h_{s}-h_{s b}\right) A, h_{a}<h_{s b},
\end{gathered}
$$

where

$Q=$ rate of leakage, in cubic feet per second;

$\frac{k^{\prime}}{b^{\prime}}=$ streambed leakance, or ratio of vertical hydraulic conductivity of the streambed, in feet per day, to thickness of the streambed, in feet;

$h_{s}=$ altitude of stream stage, in feet;

$h_{a}=$ altitude of water table in aquifer, in feet;

$A=$ wetted area of streambed reach, in square feet; and

$h_{s b}=$ altitude of streambed, in feet.

Using a value of discharge at any given river node, the model computes the altitude of the river stage as the sum of the specified streambed altitude and the river stage determined from the river stage-discharge rating tables used by the U.S. Geological Survey to determine daily discharge at the streamflowgaging stations at Wamego and Topeka. The rating table for Wamego is used in the model for river nodes about half way to Topeka, and the Topeka rating table is used for the remaining downstream river nodes. Additionally, the river-node streambed area is calculated in the model from assigned length and width dimensions for each node. Values of river stage and river-node streambed area along with assigned values of streambed leakance and the altitude of the water table in the aquifer are used by the model in applying equation $3 a$ or $3 b$ to compute the rate of stream-aquifer leakage. The computed discharge at that river node is adjusted by the stream-aquifer leakage before being carried to the next downstream node. For each time step this computational scheme is repeated at each river node from the upstream end to the downstream end. 


\section{Evapotranspiration}

When the water table or capillary fringe is within the root zone, discharge can occur directly from the aquifer as ground-water evapotranspiration. If the potential evapotranspiration is more than the applied water rate and if the water table is located within a specified depth below land surface, then ground-water evapotranspiration will occur. Thus, simulated ground-water evapotranspiration varies between a maximum (potential evapotranspiration), when the water table is at land surface, to zero, when the water table is at some specified evapotranspiration extinction depth. Because corn is the dominant crop in the study area and has a rooting depth of about 4 feet, ground-water evapotranspiration below this depth probably is small.

Conversely, if the applied water rate is more than the potential evapotranspiration, then recharge as deep percolation to the water table will occur. Monthly mean potential evapotranspiration values for the 40-year period, 1948-87, were supplied by the U.S. Bureau of Reclamation using their BASIN2 model (Otradovsky, 1986) with the option for the Jensen and Haise (1963) evapotranspiration determination method.

\section{Model Calibration}

Use of the digital-computer model as a predictive tool is predicated on the premise that, if historic hydrologic conditions can be approximated by the model, then so could future conditions. For the premise to be true, the cause-and-effect relation between the flow system's stresses and the system's responses to those stresses must be simulated accurately by the model. It also is necessary that the cause-and-effect relation in the real system not change appreciably during the period (past or future) of model simulation.

The digital model of the Kansas River valley stream-aquifer system was developed by incorporating a mathematical representation of the geohydrologic characteristics of the real flow system in the computer program. Most of the developmental efforts were spent in preparing the input data and calibrating the model to simulate the cause-and-effect relation of 40 years (1948-87) of historic conditions of precipitation, evapotranspiration, applied irrigation, streamflow, surface-water diversions, pumping, and water levels.

The model calibration process involved numerous trial simulations. To assess the model's ability to simulate observed variations, comparisons were made during the calibration process, between:

(1) The mapped and simulated water levels for the spring of 1956,1967 , and 1987 (by computing mean absolute difference of nodal simulated values from mapped values);

(2) The observed and simulated water-level hydrographs for the sites of all 43 multiple-measurement observation wells; and

(3) The measured and simulated streamdischarge hydrograph for the downstream gaging station at Topeka.

During the calibration process, excessively high simulated water levels were shown to coincide with areas overlain by large tributaries that flow across the valley-fill deposits before joining the main stem of the Kansas River. Because tributaries are not accounted for directly by this model, a line of closely spaced wells was placed along the centerline of each of these tributaries to simulate the effect of the stream valley acting as a drain to the aquifer along each tributary and thus, lower the simulated aquifer water levels in these areas (fig. 13). Data from gaged tributaries provided a guide for these modeled discharge rates, but the rates were varied somewhat to achieve reasonable simulated water levels.

Values for hydraulic conductivity, specific yield, soil-moisture capacity, and streambed leakance were adjusted within reasonable hydrologic limits until the model could approximate satisfactorily the measured variations in aquifer water levels and stream discharge. Sensitivity analyses (described in the next section of the report) defined the relative sensitivity of model results to the various model-input variables, as well as helping to determine the most satisfactory model-input values. Final values, termed "calibration 
values," for the principal variables characterizing the stream-aquifer system were:

$\begin{array}{lcl}\text { Hydraulic conductivity } & 510 & \text { feet per day } \\ \text { Specific yield } & 0.15 & \text { dimensionless } \\ \text { Streambed leakance } & 0.014 & \text { per day } \\ \begin{array}{l}\text { Soil-moisture capacity } \\ \begin{array}{l}\text { Ground-water } \\ \text { evapotranspiration }\end{array}\end{array} & 10 & \text { inches } \\ \text { extinction depth } & & \text { feet }\end{array}$

Final steady-state and 40-year simulations were conducted using the calibration values for model input. A steady-state simulation used average precipitation and streamflow data for 1931-47 to produce results presumed to represent approximate pre-1948 conditions. These results provided a reasonable initial water-level distribution for a 1948-87 transient simulation.

Results of the 1948-87 transient simulation are described in terms of the adequacy of simulated water levels, streamflow, and aquifer fluxes (inflow and outflow). Contours of simulated aquifer water levels for March 15, 1987, were compared to those for water levels measured in February and March 1987 (fig. 14). The measured water levels are given in table 2. Some of the differences between measured and simulated water levels may result because the measured water levels were determined over a period of a few weeks instead of an instant in time. Areal differences between measured and simulated water levels could be due to closeness of some observation wells to centers of pumping or areas of applied irrigation water, uniformly modeled hydraulic conductivity, specific yield, and streambed leakance, and differential discharge to tributary streams instead of the assumed uniform discharge along the tributaries. Contours of simulated and published water levels for the spring of 1956 and of 1967 also were compared during the calibration process. Generally, simulated 1956 contours had a poorer match with published contours (Beck, 1959), and simulated 1967 contours had a comparable or better match with the published contours (Fader, 1974) than did simulated 1987 contours compared to measured water levels for February-March 1987. These differences probably are due to the lack of information on metered pumpage rates, seasonal variations in historical pumpage, and irrigation-distribution data, thus necessitating the estimation of monthly pumpage data on the basis of crop-irrigation (farm-delivery) requirements.

Selected hydrographs of measured and simulated water levels for some of the 43 multiple-measurement observation wells are shown in figures 15 and 16. As shown by the hydrographs, in some areas simulated water levels match measured water levels fairly close, whereas in other areas simulated water levels are too high or too low. For most of the observation wells, simulated water levels tended to fluctuate in unison with measured water levels, although the amplitudes did not necessarily agree. The general agreement of water-level fluctuations probably is due to model input of monthly precipitation representing water applied uniformly to the land surface at each node over the entire modeled area. The simulated water levels in the Topeka area, especially north of the Kansas River, tend to be higher than measured water levels. This may be because, in the urban area, with more pavement and rooftops, actual water levels are lower than in the rest of the modeled area because much of the precipitation that is modeled as potential recharge to the aquifer actually runs off through the storm sewers to the river. To the west of the Topeka urban area, simulated water levels generally tend to be lower than measured water levels. These areal differences probably reflect, in part, the effect of using a uniform hydraulic conductivity and specific yield in the model. Simulated water levels for wells near the river tend to match measured water levels very well and probably are affected somewhat by interaction of the daily discharges of the river with the aquifer.

Discharge hydrographs for the gaging station at Topeka (measured and simulated) for two selected 5-year periods are shown in figure 17. Generally, the simulated streamflow agrees with the measured discharge at the Topeka gaging station.

Besides simulating water levels and streamflow, the transient model simulates hydrologic fluxes. Average simulated rates of 


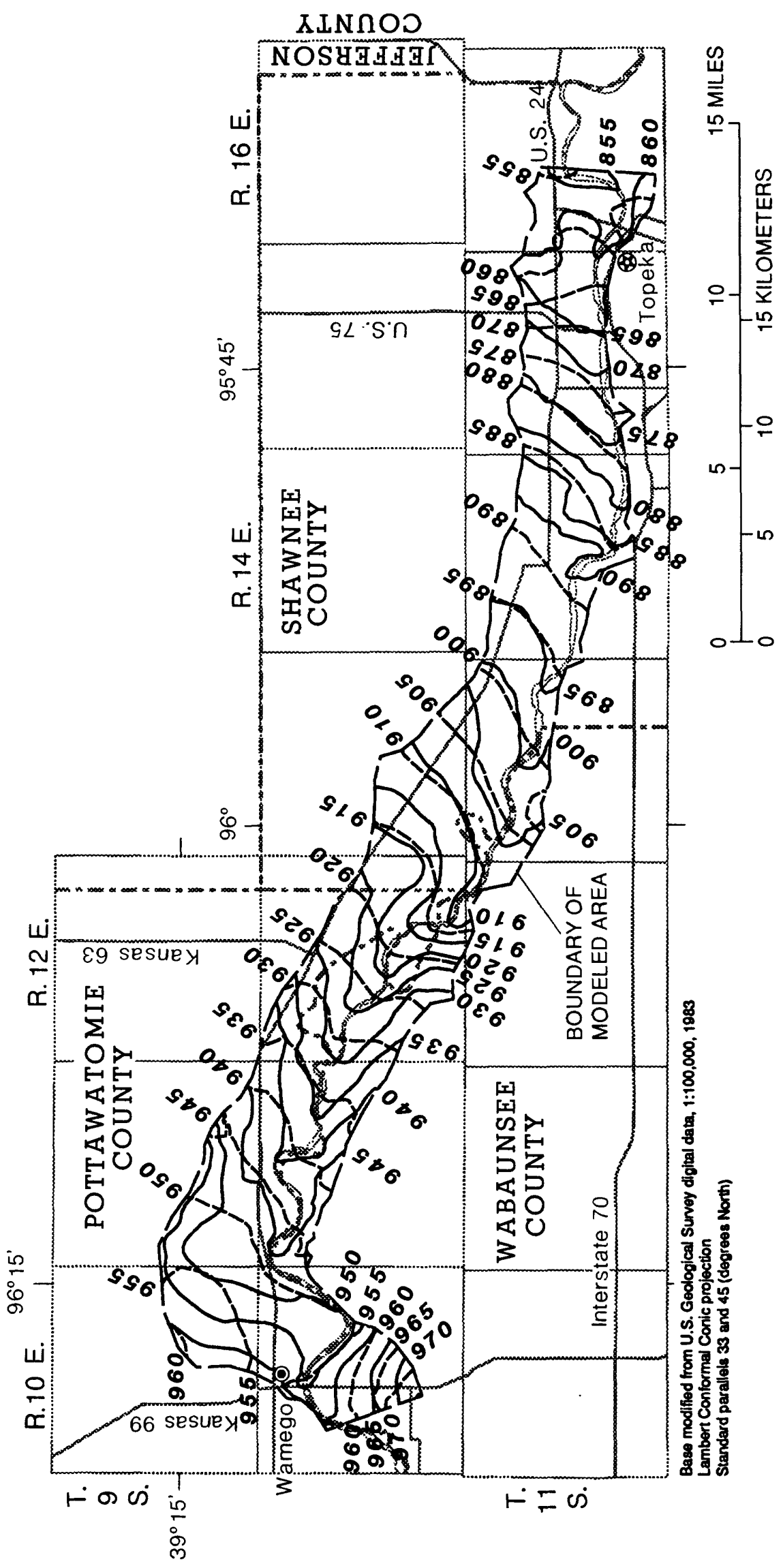

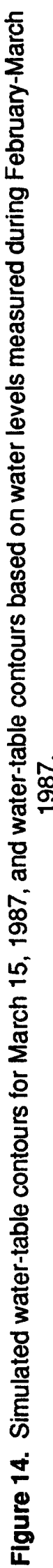


Table 2. Measured water levels, February-March 1987 [--, depth information not available]

\begin{tabular}{|c|c|c|c|}
\hline $\begin{array}{l}\text { Well number } \\
\text { (fig. 6) }\end{array}$ & $\begin{array}{c}\text { Date of } \\
\text { measurement } \\
\text { (month/day/ } \\
\text { year) }\end{array}$ & $\begin{array}{c}\text { Altitude of } \\
\text { water table } \\
\text { above sea } \\
\text { level (feet) }\end{array}$ & $\begin{array}{l}\text { Depth of well } \\
\text { (feet) }\end{array}$ \\
\hline 09S-11E-19CDB & $2 / 04 / 87$ & 950 & -- \\
\hline 09S-11E-27CAA & $2 / 04 / 87$ & 957 & 43.0 \\
\hline 09S-11E-27CDA & $3 / 05 / 87$ & 951 & 63.0 \\
\hline 09S-11E-28DBC & $3 / 05 / 87$ & 951 & -- \\
\hline 09S-11E-29CCB & $3 / 04 / 87$ & 950 & - \\
\hline 09S-11E-29DDA & $3 / 05 / 87$ & 951 & -- \\
\hline 09S-11E-31DCC & $2 / 04 / 87$ & 947 & 26.0 \\
\hline 09S-11E-32ADC & $2 / 04 / 87$ & 948 & -- \\
\hline 09S-11E-33BCA & $3 / 05 / 87$ & 945 & -- \\
\hline 09S-11E-34CAB & $2 / 04 / 87$ & 945 & 66.0 \\
\hline 09S-11E-35DBD & $3 / 04 / 87$ & 946 & -- \\
\hline 09S-11E-35DDD & $2 / 04 / 87$ & 943 & 45.0 \\
\hline 09S-11E-36CDD & $3 / 04 / 87$ & 943 & -- \\
\hline 10S-10E-10DBC & $2 / 04 / 87$ & 954 & 67.0 \\
\hline 10S-10E-15DCC & $3 / 04 / 87$ & 960 & 39.0 \\
\hline 10S-11E-01ADA & $3 / 04 / 87$ & 941 & -- \\
\hline 10S-11E-01CBC & $2 / 04 / 87$ & 934 & 81.0 \\
\hline 10S-11E-02BBA & $3 / 04 / 87$ & 943 & -- \\
\hline 10S-11E-03BCA & $2 / 04 / 87$ & 943 & 45.5 \\
\hline 10S-11E-03BDB & $3 / 05 / 87$ & 941 & -- \\
\hline 10S-11E-03BDD & $3 / 05 / 87$ & 942 & -- \\
\hline 10S-11E-04ACB & $2 / 04 / 87$ & 944 & 85.0 \\
\hline 10S-11E-04BAB & $3 / 04 / 87$ & 945 & -- \\
\hline 10S-11E-05BBC & $3 / 04 / 87$ & 947 & -- \\
\hline 10S-11E-11ACB & $3 / 04 / 87$ & 937 & -- \\
\hline 10S-12E-05BCD & $3 / 04 / 87$ & 940 & -- \\
\hline 10S-12E-06ADA & $3 / 04 / 87$ & 942 & - \\
\hline 10S-12E-07BBC & $2 / 04 / 87$ & 934 & 84.0 \\
\hline 10S-12E-22DDA & $3 / 05 / 87$ & 918 & -- \\
\hline 10S-12E-25DBA & $3 / 05 / 87$ & 923 & - \\
\hline 10S-12E-25DBD & $3 / 05 / 87$ & 922 & -- \\
\hline
\end{tabular}


Table 2. Measured water levels, February-March 1987--Continued

\begin{tabular}{|c|c|c|c|}
\hline $\begin{array}{l}\text { Well number } \\
\text { (fig. 6) }\end{array}$ & $\begin{array}{c}\text { Date of } \\
\text { measurement } \\
\text { (month/day/ } \\
\text { year) }\end{array}$ & $\begin{array}{c}\text { Altitude of } \\
\text { water table } \\
\text { above sea } \\
\text { level (feet) }\end{array}$ & $\begin{array}{l}\text { Depth of well } \\
\text { (feet) }\end{array}$ \\
\hline 10S-12E-29ADD & $3 / 04 / 87$ & 930 & - \\
\hline 10S-13E-30CCB & $3 / 05 / 87$ & 916 & 38.0 \\
\hline 11S-12E-01ABA & $3 / 04 / 87$ & 912 & 39.0 \\
\hline 11S-13E-03ADB & $3 / 05 / 87$ & 906 & -- \\
\hline 11S-13E-04ADA & $3 / 04 / 87$ & 903 & - \\
\hline 11S-14E-08BDC & $3 / 05 / 87$ & 896 & 70.0 \\
\hline 11S-14E-13BBB & $3 / 04 / 87$ & 890 & 48.0 \\
\hline 11S-14E-15ABB & $3 / 04 / 87$ & 891 & 50.0 \\
\hline 11S-14E-18CBB & $3 / 04 / 87$ & 894 & 44.0 \\
\hline 11S-14E-22CCC & $3 / 04 / 87$ & 892 & 66.0 \\
\hline 11S-14E-22DAC & $3 / 05 / 87$ & 886 & - \\
\hline 11S-14E-23BBD & $3 / 05 / 87$ & 884 & - \\
\hline 11S-14E-23DDD & $3 / 05 / 87$ & 881 & 48.0 \\
\hline 11S-14E-24BBB & $3 / 04 / 87$ & 886 & 38.0 \\
\hline 11S-15E-07CDC3 & $3 / 05 / 87$ & 881 & 45.0 \\
\hline 11S-15E-13CCC & $3 / 05 / 87$ & 863 & 77.0 \\
\hline 11S-15E-13DAC & $3 / 05 / 87$ & 862 & 68.0 \\
\hline 11S-15E-13DBC & $3 / 04 / 87$ & 865 & 77.0 \\
\hline 11S-15E-13DBD & $3 / 05 / 87$ & 861 & 76.0 \\
\hline 11S-15E-14ADB & $3 / 04 / 87$ & 863 & 58.0 \\
\hline 11S-185E-16DAC & $3 / 04 / 87$ & 873 & 38.0 \\
\hline 11S-15E-23DBD2 & $3 / 04 / 87$ & 864 & 52.0 \\
\hline 11S-15E-24ABC & $3 / 05 / 87$ & 861 & 53.0 \\
\hline 11S-15E-24ADA & $3 / 05 / 87$ & 861 & 77.0 \\
\hline 11S-15E-24DBD & $3 / 04 / 87$ & 861 & 32.0 \\
\hline 11S-16E-19DDD & $3 / 04 / 87$ & 860 & 50.0 \\
\hline 11S-16E-29ACA & $3 / 04 / 87$ & 857 & -- \\
\hline
\end{tabular}




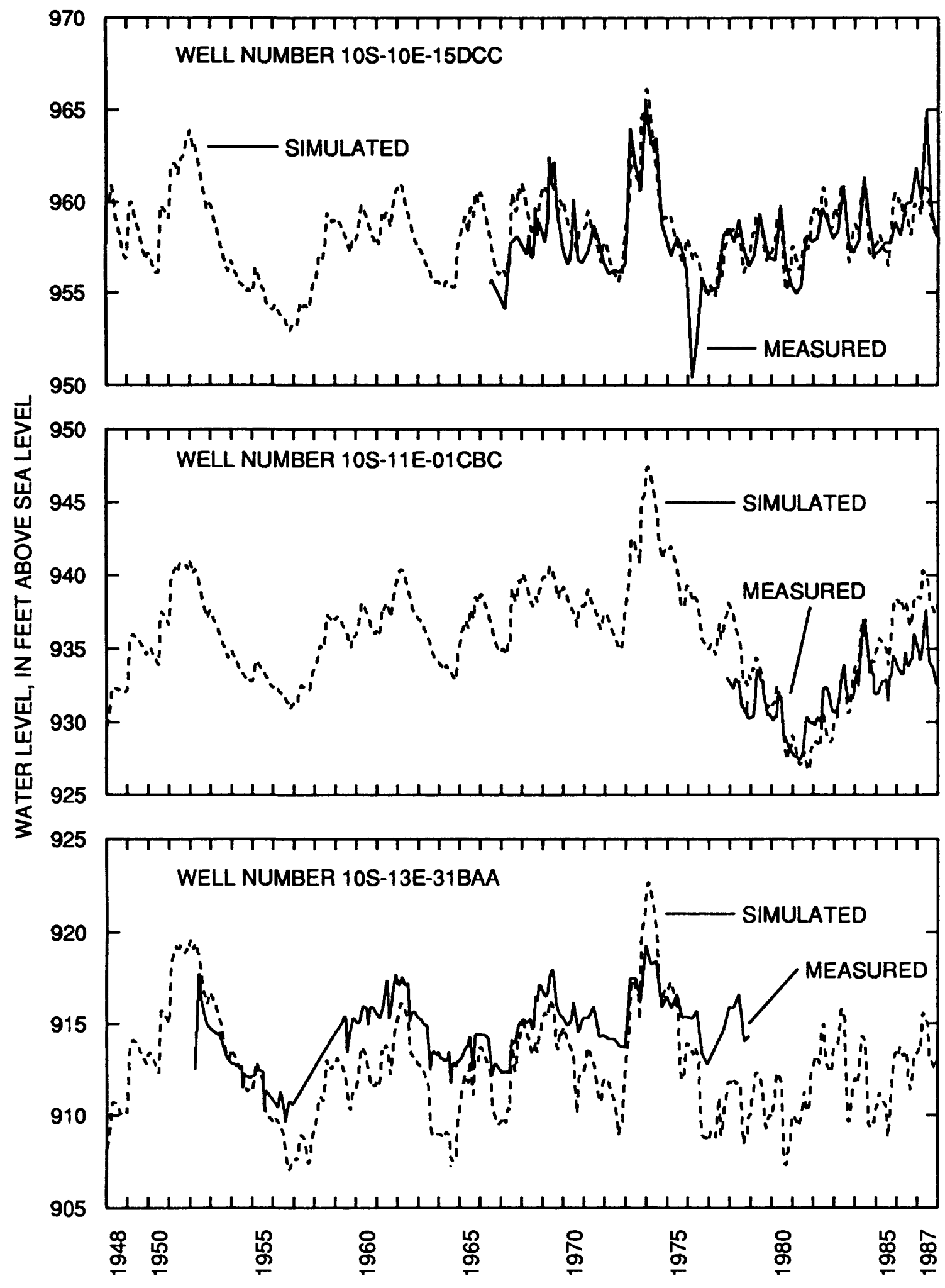

Figure 15. Measured and simulated water levels in western part of modeled area. 


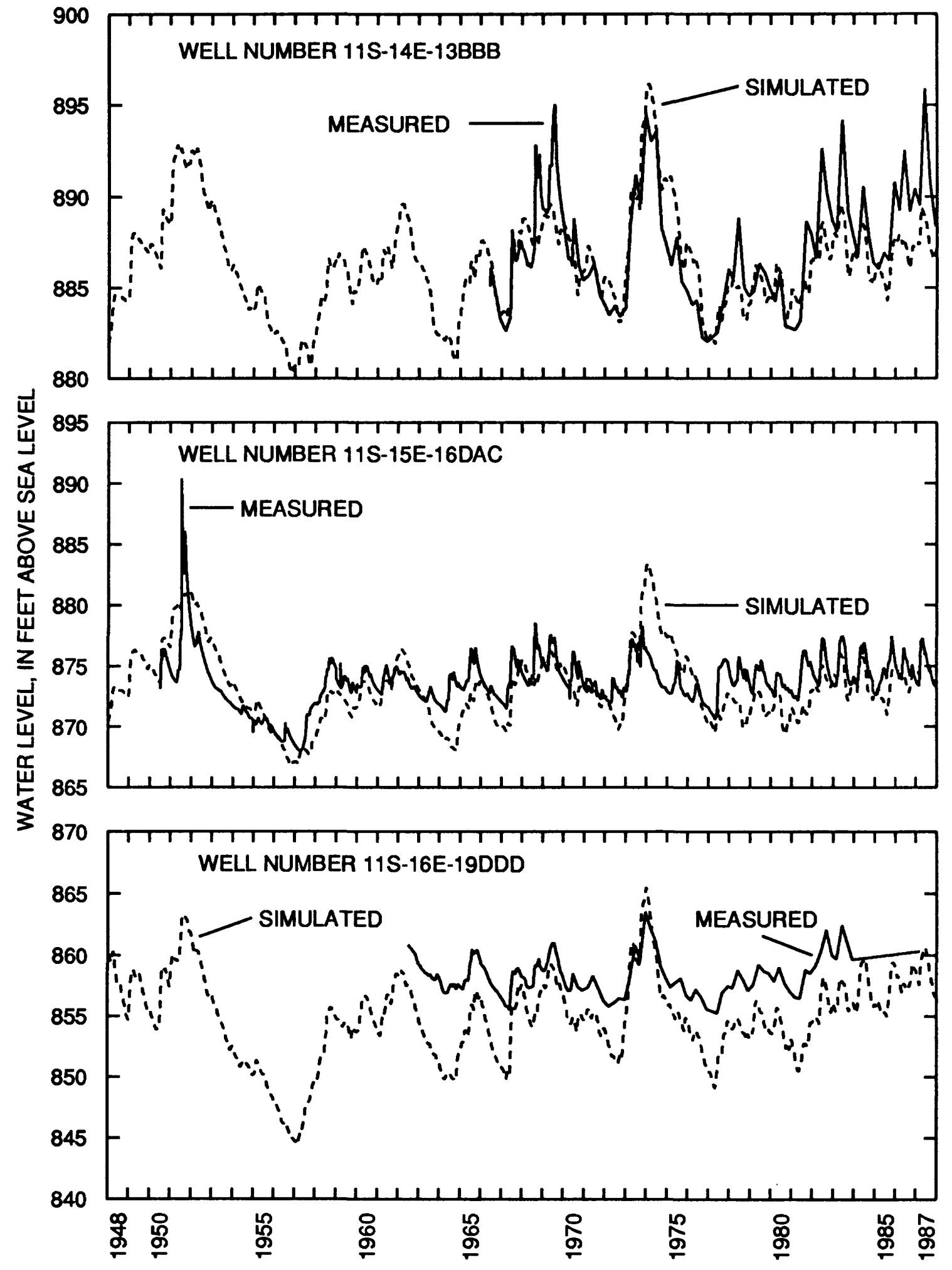

Figure 16. Measured and simulated water levels in eastem part of modeled area. 


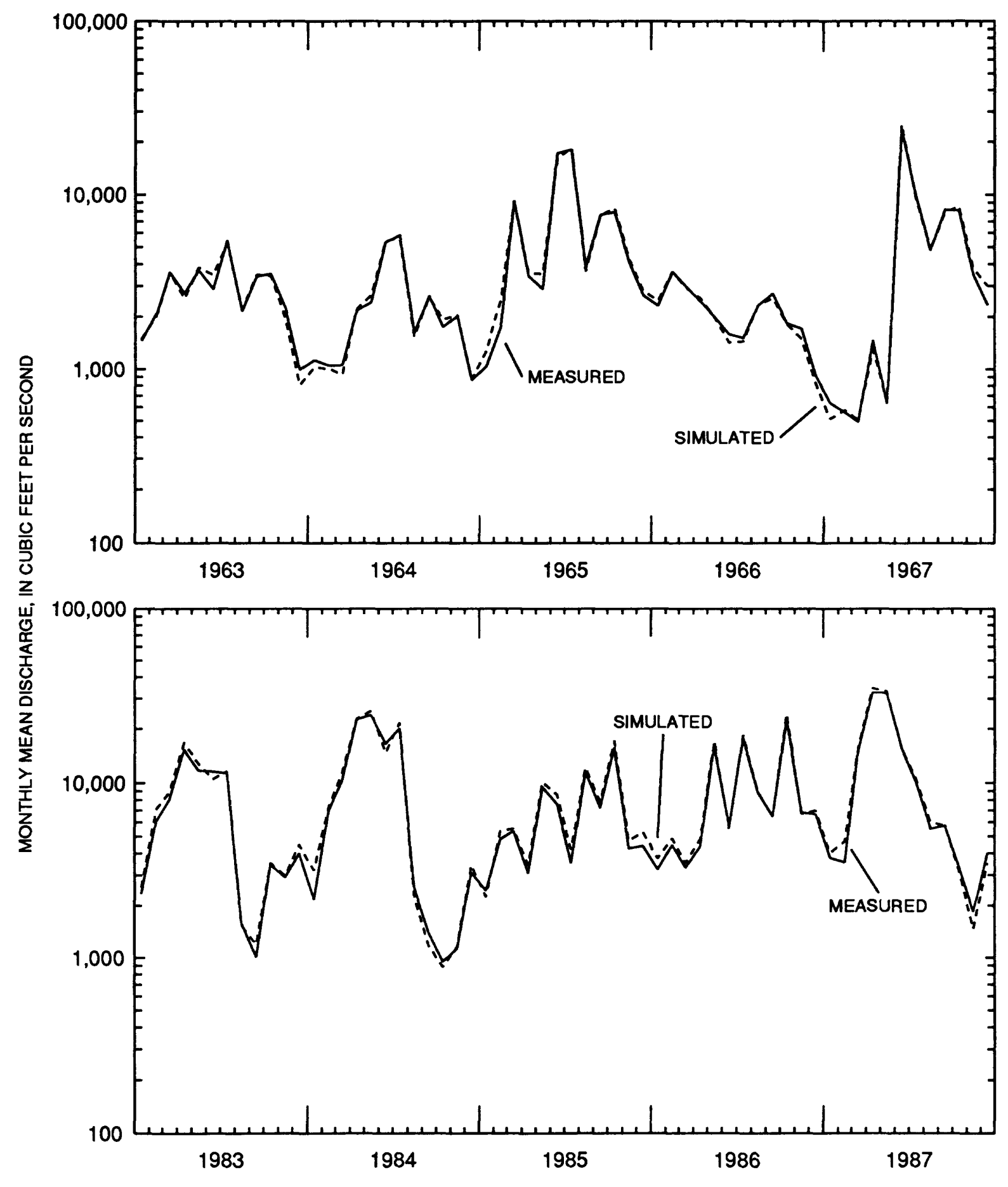

Figure 17. Measured and simulated monthly mean discharge of Kansas River at Topeka for 1963-67 and 1983-87. 
flow into and out of the aquifer system, including both the unsaturated and saturated zones, are presented in table 3 . The various component rates of flow represent average conditions for 1948-87. Based on these model results, the net storage of water within the aquifer in the model area increased at an average rate of 2 cubic feet per second, which is equivalent to an average water-level rise of about 4 feet for the 40-year period. Yearly mean drawdown, shown in figure 18 , generally follows precipitation trends, and also shows the water-level rise of about 4 feet for the 40 -year period.

The largest rate of inflow to the system was provided by precipitation at 341 cubic feet per second. The next largest component of inflow was applied irrigation water (23 cubic feet per second). Deep percolation resulting from precipitation and applied water for irrigation averaged 84 cubic feet per second.

The largest component of outflow from the entire system for the 40-year period was evapotranspiration from the unsaturated zone (280 cubic feet per second). Other outflow components included pumpage ( 42 cubic feet per second), ground-water discharge to tributaries (15 cubic feet per second), and stream-aquifer flux (27 cubic feet per second). The simulated yearly mean net stream-aquifer leakage for all 60 river nodes, presented in figure 19 , indicates that the aquifer generally discharged more to the river during wet periods when the water table was high compared to the river stage, and less to the river during dry periods when the water table was low compared to the river stage. Figures 19 and 20 illustrate the distribution in time of stream-aquifer leakage in certain reaches of the river. Simulated yearly mean net stream-aquifer leakage for the western and eastern reaches of the Kansas River from Wamego to Topeka is shown in figure 20. The river was a gaining stream each year for the 27 river nodes in the western reach (reach 1) of the modeled area (fig. 10), with the aquifer discharging more to the river during wet periods and less during dry periods. For the 33 river nodes in the eastern reach (reach 2) of the modeled area (fig. 10), which includes industrial wells in Topeka, the river became a losing stream during some dry periods but remained a gaining stream during wet periods. The difference between the two river reaches may reflect lower water levels in the Topeka area relative to river stage due to greater industrial pumpage.

The spatial distribution of the streamaquifer leakage at a particular time (December $27-31,1987$ ) is shown in figure 21 . The graph shows that, during the last 5-day time step of the 40-year simulation period for most of the river nodes, the river was a gaining stream except near Topeka where the river loses water to the aquifer.

Monthly rates of precipitation and simulated evapotranspiration during 1948-87 are shown in figure 22. Monthly rates of simulated deep percolation and estimated pumpage are shown in figure 23 , and monthly rates of surface-water diversions from the Kansas River and simulated ground-water evapotranspiration are shown in figure 24.

\section{Sensitivity Analysis}

The response of the model to changes in several variables was tested as part of the analyses. This process involved increasing or decreasing the value of a specific model-input variable over a realistic range, while all other input variables were retained at their calibration values, and re-running a 1948-87 transient simulation. Results of these variations were evaluated in terms of their effect on simulated water levels, as this was the main basis for model calibration.

Sensitivities were determined by calculating the mean absolute difference between measured and simulated water levels for the spring of 1987 (fig. 25). The mean absolute difference is about 2.5 feet for the calibration simulation. Sensitivities to precipitation, hydraulic conductivity, streambed leakance, and specific yield are illustrated, based on increasing and then decreasing each of those model inputs by 33 and 67 percent from the respective calibration values. The mean absolute difference generally increases when the model-input values are varied from calibration values. Figure 25 also shows that the model-simulated water levels are very sensitive to precipitation, and relatively insensitive to hydraulic conductivity, streambed leakance, and specific yield. 
Table 3. Simulated average water budget for Kansas River alluvial aquifer between Wamego and Topeka, 1948-87

[Values are given in cubic feet per second]

\begin{tabular}{|c|c|c|}
\hline & \multicolumn{2}{|c|}{ Land surface } \\
\hline & Recharge rate & Discharge rate \\
\hline Precipitation & 341 & 0 \\
\hline $\begin{array}{l}\text { Applied irrigation water (from ground- } \\
\text { water and surface-water sources) }\end{array}$ & 23 & $\mathbf{0}$ \\
\hline Evapotranspiration & 0 & 280 \\
\hline Totals & 364 & 280 \\
\hline \multirow[t]{3}{*}{ Net rate of recharge to aquifer } & \multicolumn{2}{|c|}{84} \\
\hline & \multicolumn{2}{|c|}{ Aquifer } \\
\hline & Recharge rate & Discharge rate \\
\hline Deep percolation & 84 & 0 \\
\hline Stream-aquifer net flux (main stem) & 0 & 27 \\
\hline Subsurface inflow (main valley) & 7 & 0 \\
\hline Subsurface outflow (main valley) & 0 & 3 \\
\hline Subsurface inflow (tributary valleys) & 7 & 0 \\
\hline Pumpage & 0 & 42 \\
\hline Ground-water evapotranspiration & 0 & 9 \\
\hline $\begin{array}{l}\text { Ground-water discharge to tributaries } \\
\text { (estimated) }\end{array}$ & 0 & 15 \\
\hline Totals & 98 & 96 \\
\hline $\begin{array}{l}\text { Net rate of increase in aquifer } \\
\text { storage }\end{array}$ & & \\
\hline
\end{tabular}




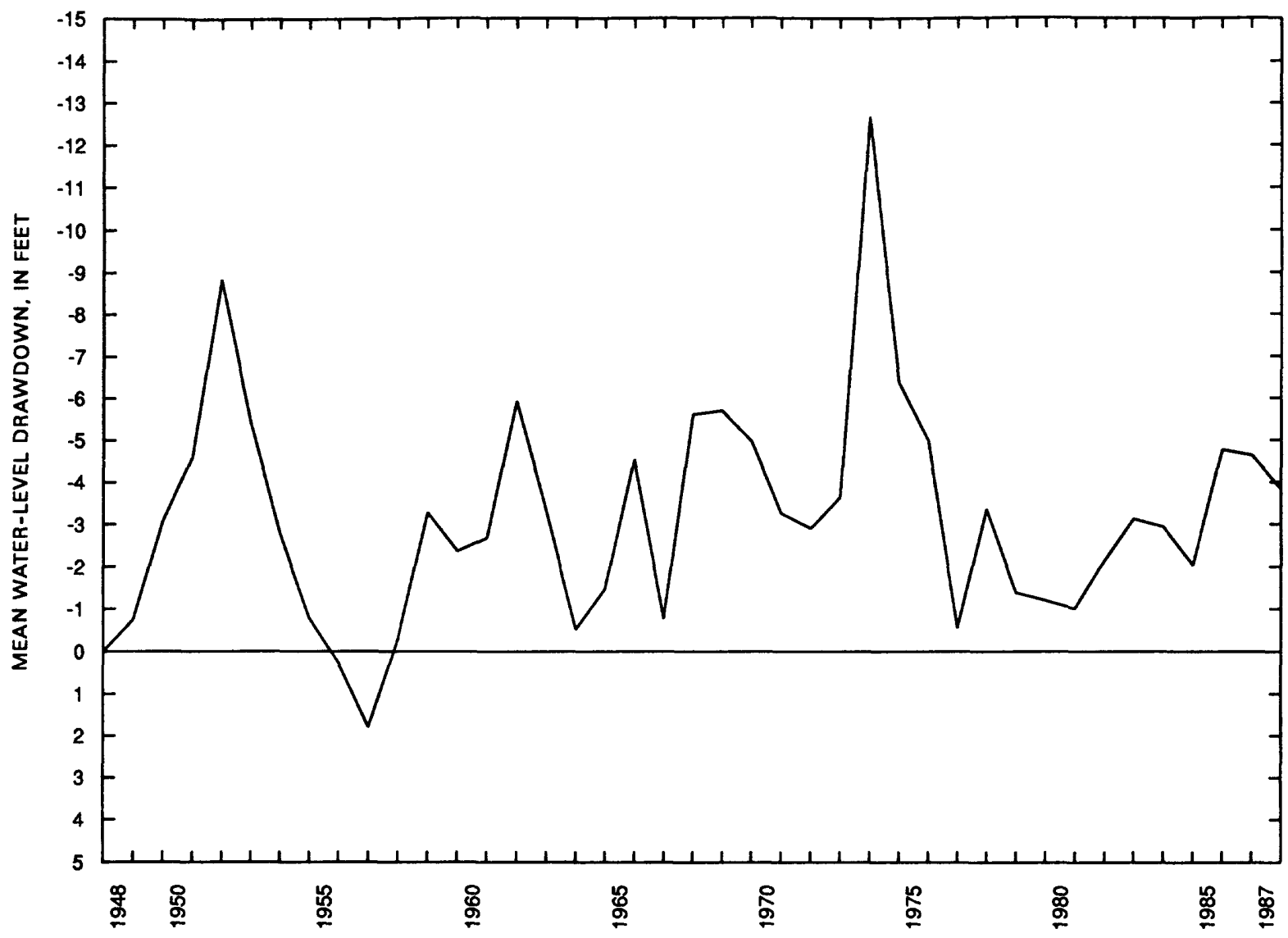

Figure 18. Simulated annual mean drawdown in alluvial aquifer in modeled area, 1948-87.

\section{SIMULATIONS OF STREAM-AQUIFER SYSTEM}

Of the 13 model simulations of hypothetical conditions, the first 9 were made by projecting various patterns of streamflow (at Wamego and at the several points of diversion and tributary inflow), precipitation, and hypothetical pumping options for 8 years and noting the resultant hydraulic heads and downstream discharge. The last four simulations represent various upstream reservoir releases during severe drought conditions. These simulations are numbered 1 through 13 for purposes of this discussion.

The cyclic patterns of streamflow, precipitation, and pumping used in the model simulations allowed the aquifer to reach a state of dynamic equilibrium (recharge nearly equals discharge) after just a few years with no long-term water-level change or change in storage. Strictly speaking, a constant steadystate condition will not develop in a large stream-aquifer system such as that in the
Kansas River valley due to seasonal and annual variations of recharge and discharge. But if the changes in the system are cyclic and uniform, such as the patterns of streamflow and pumping in the model simulations, a dynamic steadystate condition may be reached wherein changes in storage are negligible and water levels show little change from cycle to cycle.

Years of above-average, near-average, or below-average (1987, 1962, and 1963, respectively) streamflow and precipitation, coupled with pumping options of continued 1987 ground-water withdrawals, a 50-percent increase of 1987 withdrawals, and a 100-percent increase of 1987 withdrawals were cycled for 8 years for the 13 model simulations. Simulated ending water levels from the 1948-87 transient simulation were used as initial water levels for these simulations of hypothetical conditions. The 8-year duration was selected arbitrarily to represent an extended period of abnormally dry or wet hydrologic conditions.

The mean drawdowns for the entire modeled area resulting from the first nine simulations 


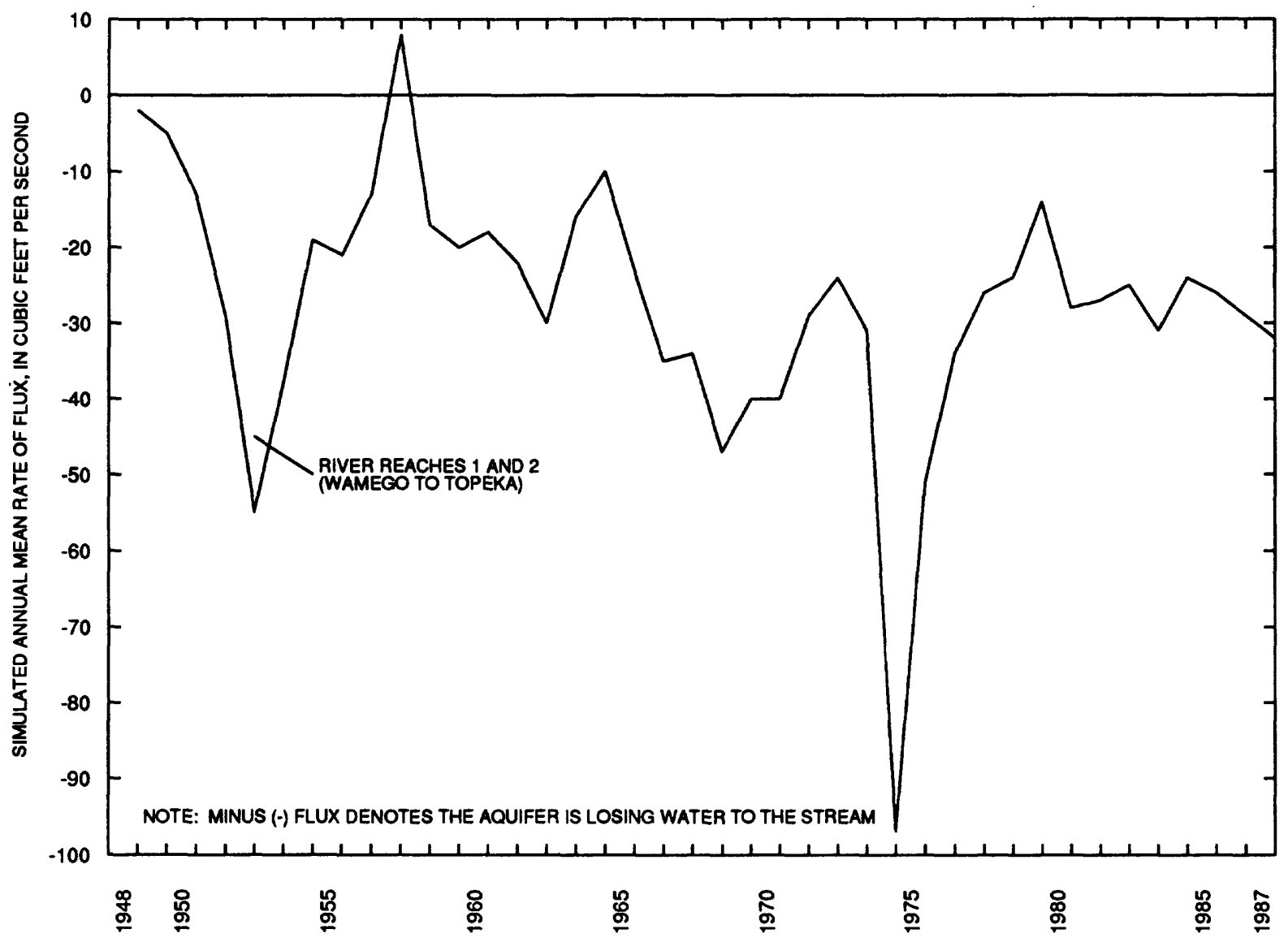

Figure 19. Simulated annual mean net stream-aquifer leakage in the Kansas River valley from Wamego to Topeka, 1948-87.

are shown in figure 26 . The mean drawdowns plotted on this graph were calculated by dividing total storage change at the end of each year by modeled area and specific yield. It should be noted that these values represent mean drawdowns for the entire area, so that, at any particular place, the drawdown may vary markedly, either above or below these mean values. Computing the mean drawdown provides a single value that enables direct comparisons of various model simulations.

Yearly mean rates of pumping, deep percolation, and net stream-aquifer leakage also are discussed for each simulation in the following paragraphs. Yearly mean net stream-aquifer leakage along the entire Wamego-Topeka river reach for nine of the simulations is shown in figure 27 .
Simulations 1, 2, and 3: Above-average streamflow and precipitation with variations of 1987 pumpage

For simulations 1,2 , and 3 , above-average streamflow and precipitation were represented by repeating, for the 8-year simulation period, 1987 daily discharge for the Kansas River at Wamego and tributary inflow and 1987 area-averaged precipitation (for Wamego, Rossville, and Topeka). Pumpage for simulations 1,2 , and 3 consisted of continuing the 1987 ground-water withdrawals for the 8-year period (simulation 1), increasing the 1987 withdrawals by 50 percent (simulation 2 ), and increasing the 1987 withdrawals by 100 percent (simulation 3 ). Although simulated withdrawals were 


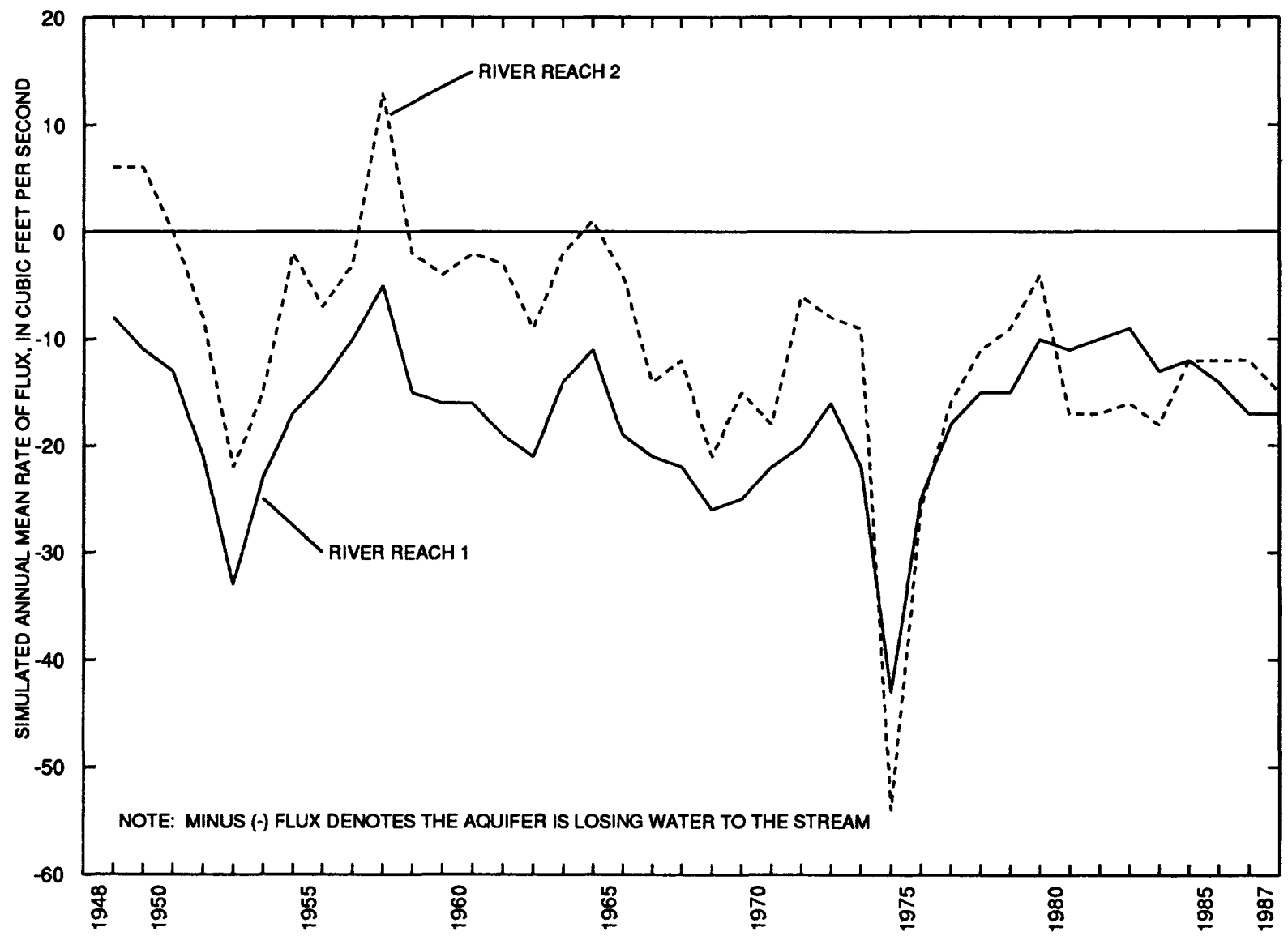

Figure 20. Simulated annual mean net stream-aquifer leakage for western (reach 1) and eastern (reach 2) reaches of the Kansas River in modeled area, 1948-87.

increased, the distribution of pumped wells was retained according to that shown in figure 12.

Computed yearly average drawdowns for simulations 1,2 , and 3 are shown in figure 26 . By the end of the 8 years of simulation, the average drawdown or lowering of water levels throughout the modeled area of the aquifer reached "steady-state" values ranging from about -2 to -4 feet. These negative "drawdowns" actually refer to a rise of water levels for these three simulations. Pumpage was about 58 cubic feet per second for simulation 1 , and, as previously indicated, 50 percent larger or 87 cubic feet per second for simulation 2 , and 100 percent larger or 116 cubic feet per second for simulation 3. Deep percolation (precipitation plus applied irrigation water minus evapotranspiration) for simulations 1,2 , and 3 averaged about 96,115 , and 134 cubic feet per second, respectively. For model simulation 1 , river reach 1 in the western part of the modeled area had a net aquifer discharge to the river that averaged about 7 cubic feet per second, and river reach 2 in the eastern part had a net aquifer discharge to the river that averaged 4 cubic feet per second. For model simulation 2, river reach 1 in the western part had a net aquifer discharge to the river that averaged about 5 cubic feet per second, whereas river reach 2 in the eastern part had a net aquifer gain from the river that averaged 1 cubic foot per second. In model simulation 3, river reach 1 had a net aquifer discharge to the river that averaged about 4 cubic feet per second, whereas river reach 2 indicated a net aquifer gain from the river that averaged 5 cubic feet per second.

\section{Simulations 4-6: Near-average streamflow and precipitation with variations of 1987 pumpage}

Model simulations 4, 5, and 6 repeated 1962 daily discharges for the Kansas River at Wamego and tributary inflows and 1962 area-averaged precipitation to represent "nearaverage" streamflow and precipitation conditions in the modeled area for the 8-year 


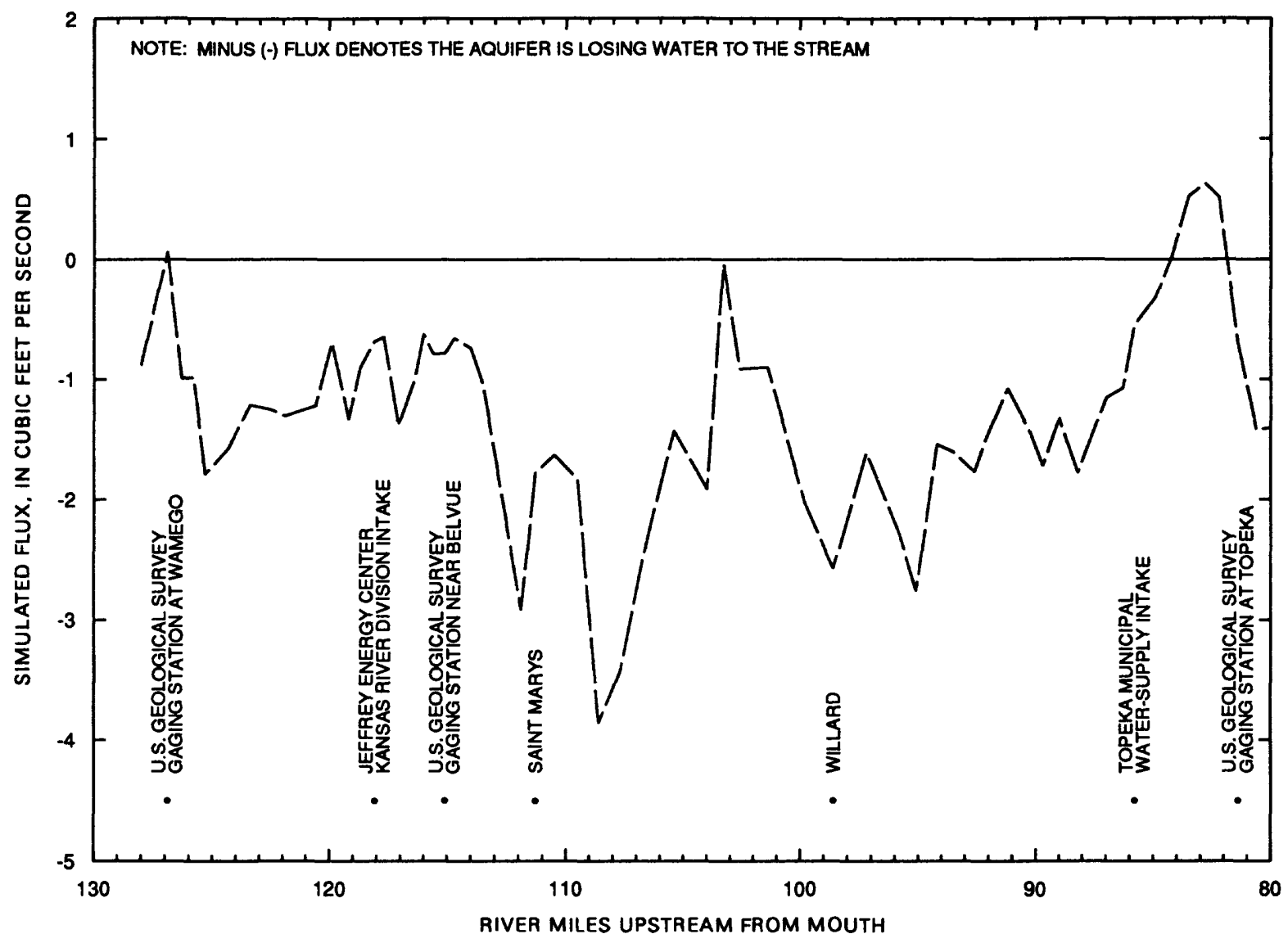

Figure 21. Simulated stream-aquifer leakage at each river node for December 27-31, 1987 (time step 73 in last year of 40 -year simulation, 1948-87).

period. Pumpage for simulations 4, 5, and 6 consisted of maintaining the 1987 withdrawals (simulation 4), increasing the 1987 withdrawals by 50 percent (simulation 5 ), and increasing the 1987 withdrawals by 100 percent (simulation 6 ).

The computed yearly average drawdown in the aquifer for the modeled area shown in figure 26 had "steady-state" values ranging from about 2 to 4 feet. Pumpage was about 58 cubic feet per second for simulation 4, 50 percent larger or 87 cubic feet per second for simulation 5 , and 100 percent larger or 116 cubic feet per second for simulation 6. Deep percolation for simulations 4,5 , and 6 , averaged about 46,63 , and 81 cubic feet per second, respectively. For simulation 4, river reach 1 in the western part of the modeled area had a net aquifer gain from the river that averaged about 5 cubic feet per second, and river reach 2 in the eastern part had a net aquifer gain that averaged 11 cubic feet per second. Simulation 5 showed that river reach 1 had a net aquifer gain from the river that averaged about 7 cubic feet per second, and river reach 2 had a net aquifer gain from the river that averaged 16 cubic feet per second. For simulation 6 , river reach 1 had a net aquifer gain from the river that averaged about 8 cubic feet per second, and river reach 2 in the east had a net aquifer gain from the river that averaged 19 cubic feet per second.

\section{Simulations 7-9: Below-average streamflow and precipitation with variations of 1987 pumpage}

In model simulations 7, 8, and 9, "below-average" streamflow and precipitation were represented for the 8-year period by repeating the 1963 daily discharge for the Kansas River at Wamego and tributary inflow and 1963 averaged precipitation for the area. Pumpage for simulations 7, 8, and 9 consisted of maintaining the 1987 withdrawals (simulation 


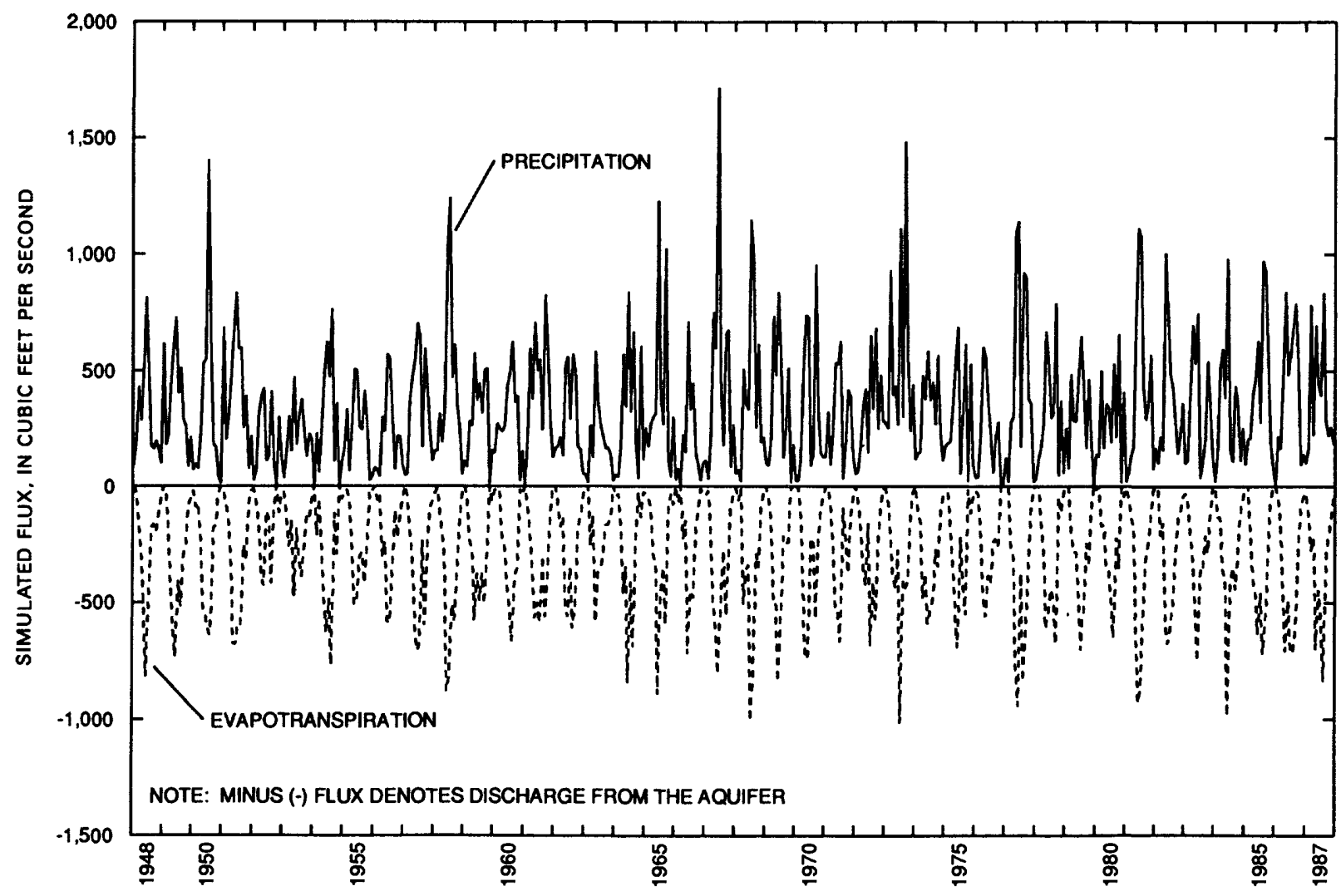

Figure 22. Monthly precipitation and simulated evapotranspiration, 1948-87.

7), increasing the 1987 withdrawals by 50 percent (simulation 8), and increasing the 1987 withdrawals by 100 percent (simulation 9 ).

Yearly mean drawdowns in the aquifer computed for simulations 7,8 , and 9 are shown in figure 26. The mean drawdown throughout the modeled area had "steady-state" values ranging from about 6 to 10 feet. Pumpage was about 58 cubic feet per second for simulation 7 , 50 percent larger or 87 cubic feet per second for simulation 8 , and 100 percent larger or 116 cubic feet per second for simulation 9. Deep percolation for simulations 7,8 , and 9 averaged about 22, 37, and 54 cubic feet per second, respectively. For simulation 7 , river reach 1 in the western part of the modeled area had a net aquifer gain from the river that averaged about 9 cubic feet per second, and river reach 2 in the eastern part had a net aquifer gain from the river that averaged 11 cubic feet per second. Simulation 8 showed that river reach 1 had a net aquifer gain from the river that averaged about 11 cubic feet per second, and river reach 2 had a net aquifer gain from the river that averaged 15 cubic feet per second. For simulation 9 , river reach 1 in the west had a net aquifer gain from the river that averaged about 13 cubic feet per second, and river reach 2 in the east had a net aquifer gain from the river that averaged 18 cubic feet per second.

\section{Simulation 10: Variation of simulation 7}

Simulation 10 is the same as simulation 7 for the first 7 years, but then changes to 1-day time steps in the 8 th year. Simulation 10 was the basis of comparison for the next three simulations (simulations 11, 12, and 13), each with different simulated upstream reservoir releases. The discharge of the Kansas River at each river node for time step 220 (August 8 in the 8th year) for simulation 10 is shown as a solid line in figure 28 . This curve, which represents drought conditions, is relatively horizontal, but overall it trends slightly downward with a few slightly upward-sloping 


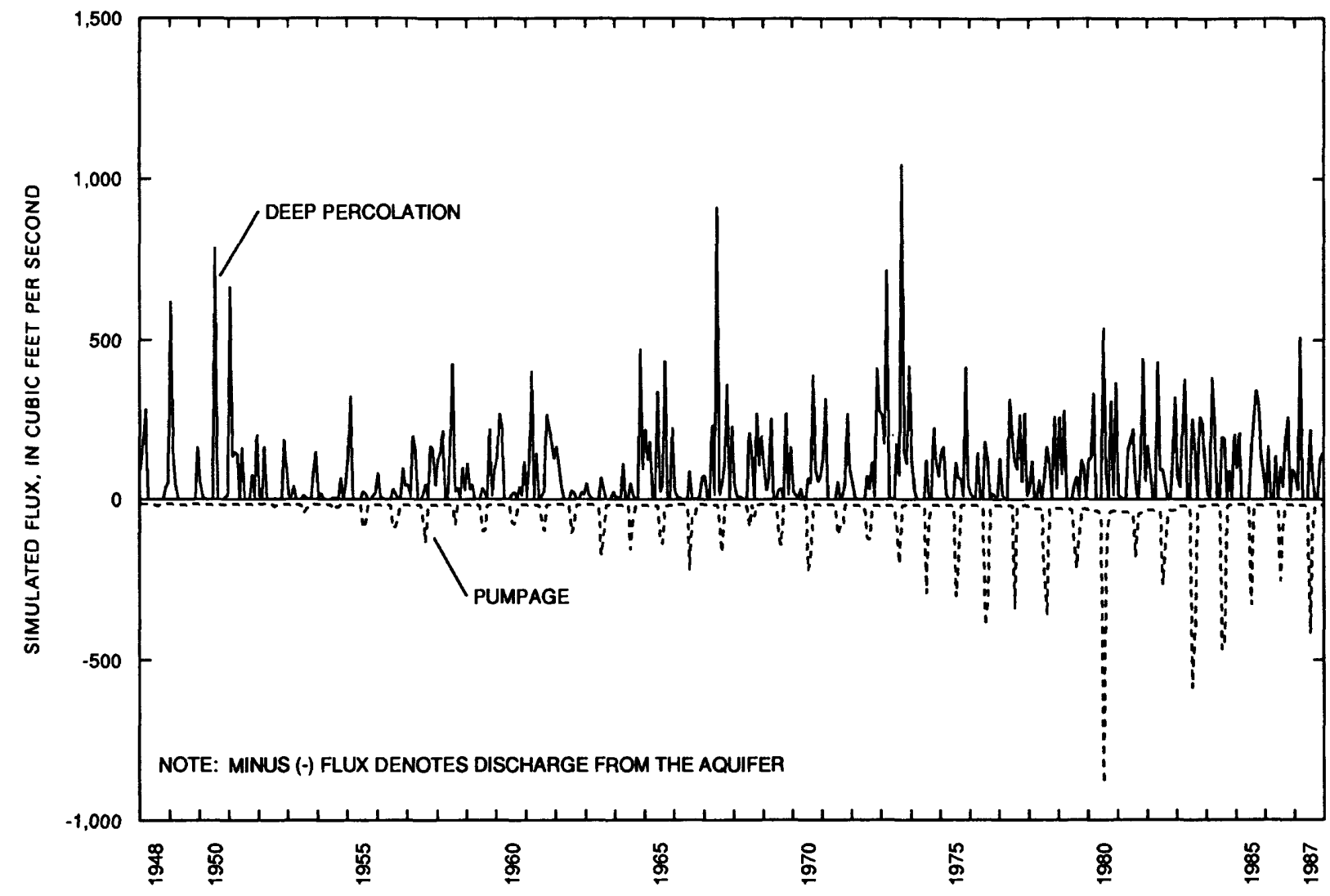

Figure 23. Monthly simulated deep percolation and estimated pumpage, 1948-87.

steps at tributary inflow points and two large, very abrupt downward-sloping steps at the two large surface-water diversion points at the Jeffrey Energy Center intake and the Topeka municipal water-supply intake. The overall downward trend implies that the river is a losing stream at this time. A plot of the stream-aquifer leakage for the same time step, shown in figure 29 , indicates that the river is represented as a losing stream on this day during the simulated drought as indicated by positive flux for most of the river nodes. This is in contrast to figure 21 , which shows the conditions during periods of above-average streamflow and precipitation, with most river nodes having negative flux and indicating that the river is a gaining stream most of the time.

\section{Simulations 11-13: Variation of simulation 10, changes in river discharge/reservoir releases}

Simulations 11,12 , and 13 are identical to simulation 10 except that for 10 time steps, starting with time step 220 (August 8 in the 8th year), the daily discharge of the Kansas River at Wamego is increased by 50 (simulation 11), 100 (simulation 12), and 500 (simulation 13) cubic feet per second to simulate the results of upstream reservoir releases of whatever amount necessary to sustain these flow rates as the releases reach Wamego. The simulated discharge at each river node for time step 220 (August 8) also is shown for each of the three different reservoir releases (fig. 28). Inspection of the graph shows that the curve for each simulated release is elevated above the no-release curve by the appropriate amount at Wamego. Although not discernible in figure 28, there is a slight downstream convergence of the release curves toward the no-release curve. The progressive downstream increase in percentage loss of the simulated releases for the 1st, 5th, and 10th day after initial release is shown in figure 30. There is an approximate 1.8-percent loss at the downstream end for all three releases on day 1 , about a 1.6-percent loss on day 5 , and about a 1.2-percent loss on day 10 as conditions 

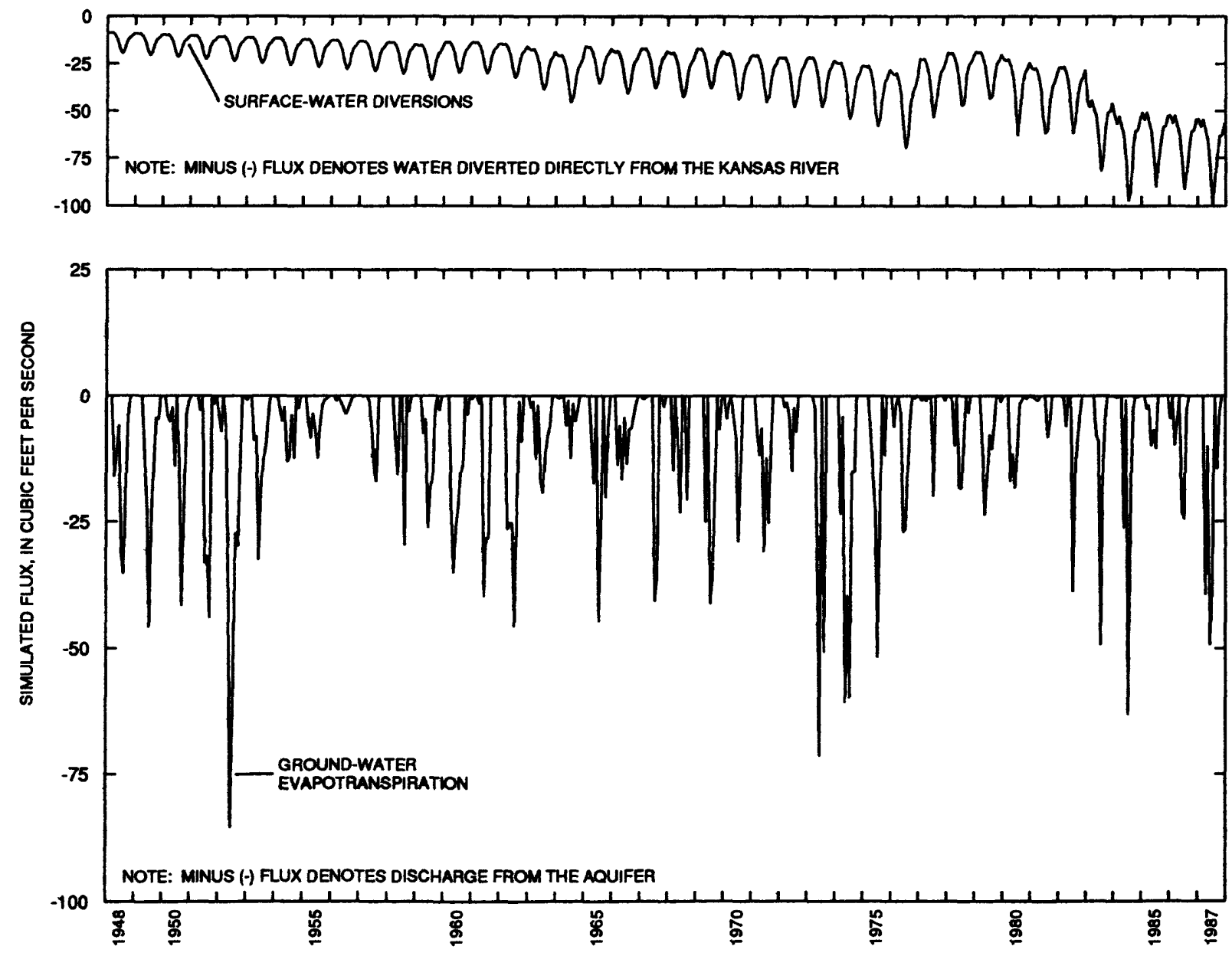

Figure 24. Monthly surface-water diversions from Kansas River and simulated ground-water evapotranspiration, 1948-87.

in the stream-aquifer system approach a new equilibrium. The progressive temporal decrease in percentage loss of one (100 cubic feet per second) of the three releases at selected points (namely, the two large surface-water diversion intakes) downstream is shown in figure 31 . Together, figures 30 and 31 show that the farther downstream from the release point, the greater the percentage loss and the longer the time necessary to re-establish equilibrium conditions after an initial reservoir release.

\section{Considerations in Use of Model}

Simulation results should be useful in aiding management decisions concerning stream-aquifer relations in the Kansas River valley. However, it must be recognized that the model is a generalized, simplified representation of a complex hydrologic system.
The methods by which different elements of the system are represented in the model must be considered when applying the model. An important example is the use of specified heads to simulate the upgradient (west) and downgradient (east) boundaries of the modeled area. To test the effect of these simulated boundaries under very stressed conditions, simulation 9 was repeated with assigned values for those specified heads that were 10 feet lower than the values in simulation 9. These lower specified hydraulic heads may exist if ground-water development near these boundaries should ever become sufficiently intense. The test simulation retained the other very stressed conditions of simulation 9--the below-average streamflow and precipitation and the pumpage that was increased by 100 percent above 1987 withdrawals, each recycled for 8 years. Ending water levels in the test simulation were compared with ending hydraulic heads in 


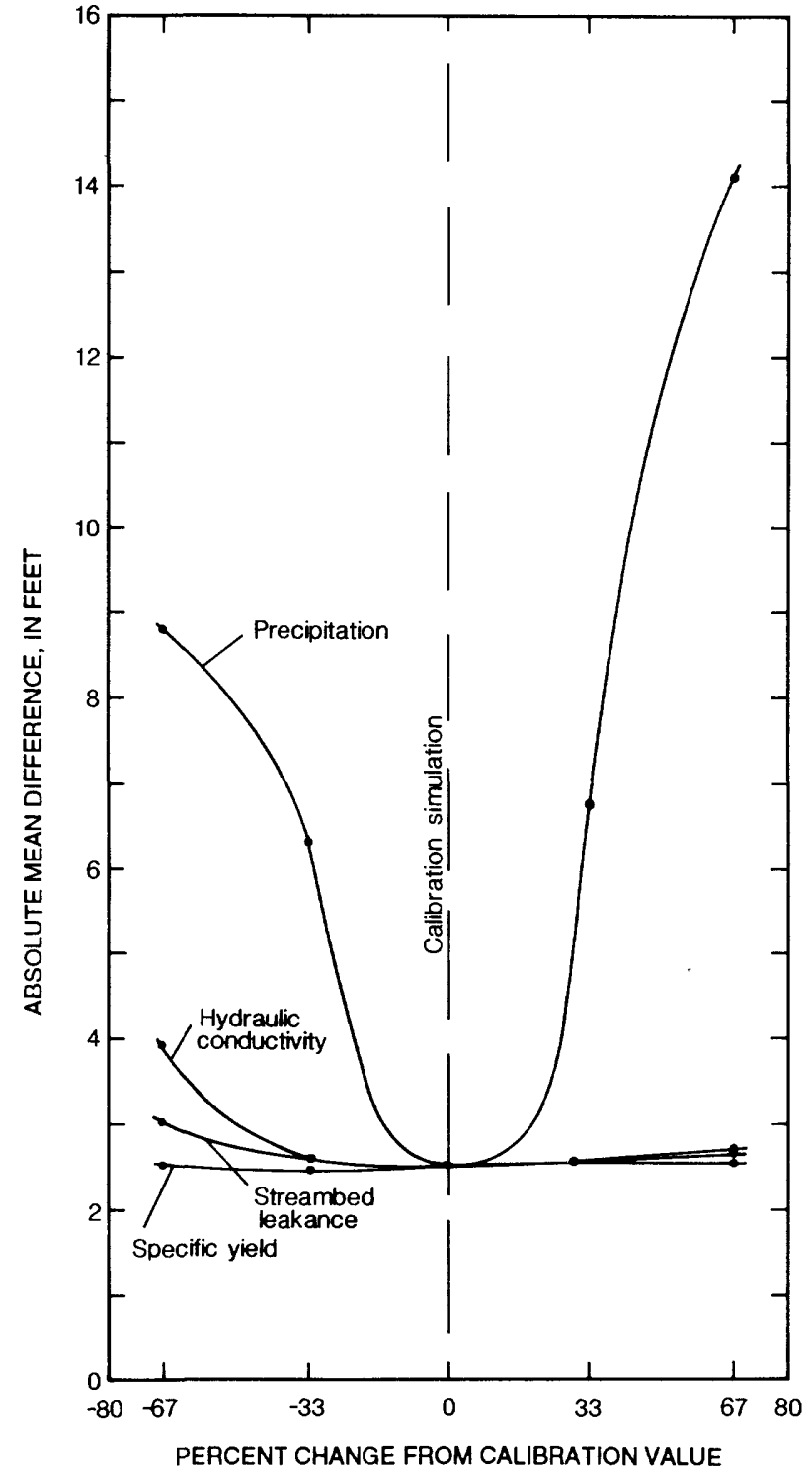

Flgure 25. Effects of variations in precipitation, hydraulic conductivity, streambed leakance, and specific yield on simulated water levels, spring 1987.

simulation 9 to evaluate the effect of the decreased specified heads. The results showed that, within about 5 miles of the west and east boundaries, the ending hydraulic heads in the test simulation were several feet lower than the ending hydraulic heads in simulation 9 . Although this test simulated an extreme condition of stress on the system, it demonstrates the potential error if specified hydraulic-head values at the boundaries are not adjusted to account for long-term pumping effects. Such adjustments were not made in the simulations of hypothetical conditions described in the preceding sections of this report.
The model user also must realize that simulation results cannot be considered accurate predictions of actual conditions. Although the overall system is satisfactorily simulated, the model is of limited application to relatively local spatial conditions or relatively short-term, temporal conditions. However, the model can be a useful guide for anticipating responses throughout a range of hydrologic conditions. For example, the 8-year simulations of above-average, near-average, and belowaverage streamflow and precipitation represent what might be considered a nearly complete range of natural climatic conditions for the area. Thus, study results can serve as a sound basis for evaluating hydrologic effects of various combinations of natural conditions, groundwater-pumping rates, and upstream reservoir releases.

\section{TRAVELTIME OF RESERVOIR RELEASES}

The surface-water accounting system of the finite-element model used does not permit evaluation of traveltimes of reservoir releases in the river. For each time step, the model increments the discharge input at the first river node at the upper end in a node-by-node fashion after accounting for water gained or lost from the aquifer at each river node until the discharge reaches the last river node at the downstream end. Therefore, any increase in input discharge simulating a rise in stage, such as a reservoir release, passes through the entire sequence of river nodes and arrives at the downstream end in the same time step, no matter what the actual traveltime of such a rise may be. Because traveltime is important for many management applications, a separate study, independent of the modeling effort, was conducted to determine traveltimes of reservoir-release rises of various magnitudes at various antecedent flow conditions. This involved searching and analyzing streamflow-gaging-station records for past reservoir-release rises to determine traveltimes to downstream points.

Traveltime data were gathered for releases from two reservoirs, Milford and Tuttle Creek Lakes. Annual discharge hydrographs for 1976-88 were superimposed on separate plots for all streamflow-gaging stations along the 


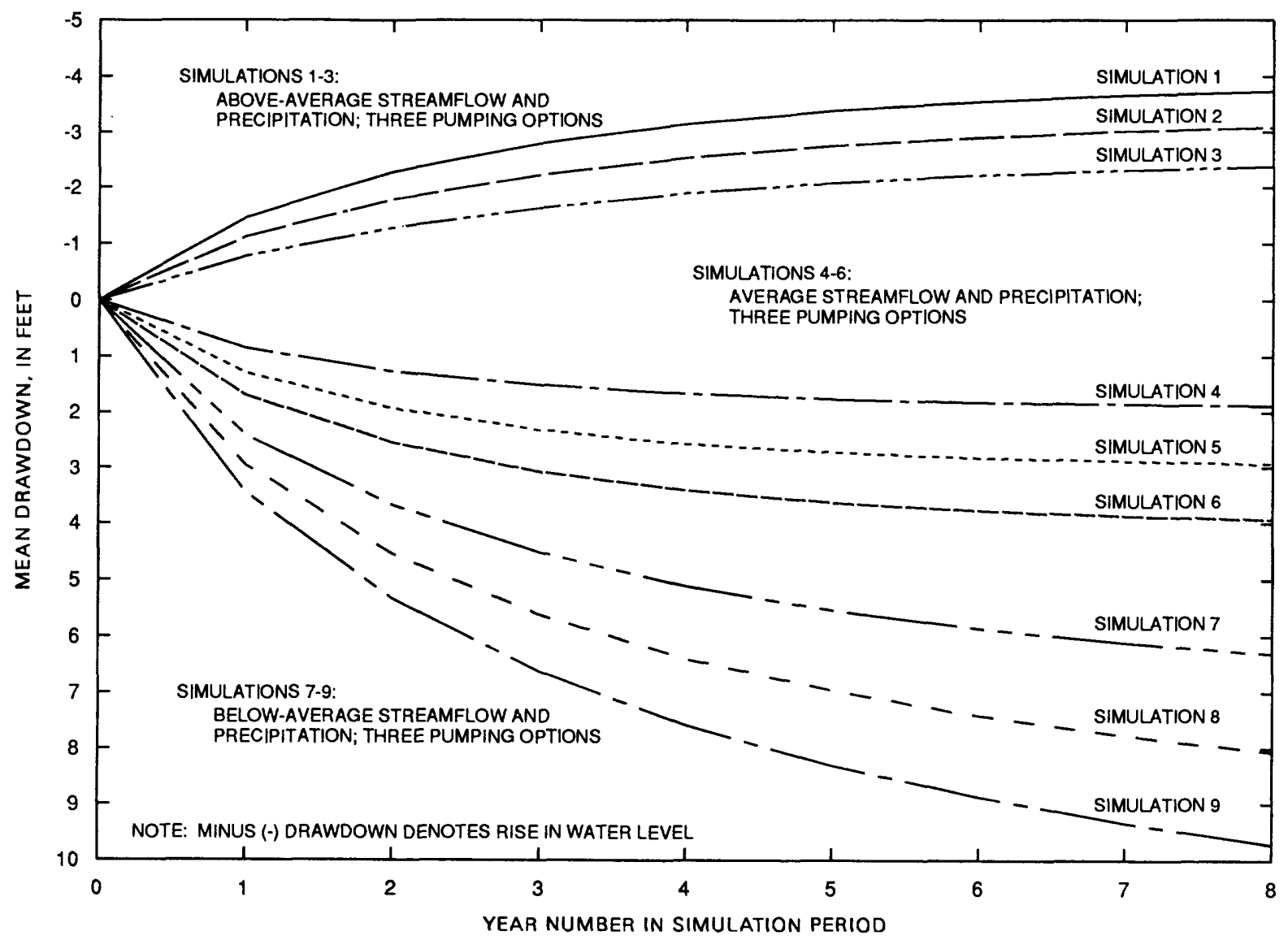

Figure 26. Annual mean drawdown in alluvial aquifer for entire modeled area for 8-year hypothetical simulations 1-9.

Kansas River, including stations located on the Smoky Hill River at Enterprise (about 43 river miles upstream of Junction City, fig. 9, map number 2), the Big Blue River near Manhattan (fig. 9, map number 12), the Republican River below Milford Dam (fig. 9 , map number 1), the Delaware River below Perry Dam (fig. 9, map number 25), and the Wakarusa River near Lawrence (fig. 9, map number 28). The hydrographs were analyzed to find separate, isolated releases from Milford or Tuttle Creek Lakes that occurred at times when no significant rainfall took place. Rainfall was identified as sharp peaks on one or more of several additional overplotted hydrographs of gaged smaller tributaries along the Kansas River valley.

The reservoir-release rises identified as isolated releases were listed with the date of occurrence. The analog stream-stage recorder charts for each downstream station then were searched for these dates to determine the arrival time, to the nearest quarter hour, of the leading edge of each selected reservoir-release rise in stage. From rise-in-stage arrival times and known gaging-station river miles, elapsed time and distance traveled to each gaging station were computed. From these computed data, the velocity of the release rise was calculated between gaging stations, as well as the overall velocity to the last station downstream at which the rise was identifiable. Discharge-record files were searched for the arrival dates and times to determine the reservoir-release discharges and antecedent discharge on the main stem Kansas River. The date, release discharge, antecedent flow of the main stem, and the average velocity of the release rise to the last station identifiable are listed for 31 releases in table 4 . The elapsed times, in hours, for each separate release rise are plotted for each gaging station at the appropriate distance and are shown in figures 32 and 33.

The reservoir releases are divided arbitrarily on the graph into "small" and "large" 


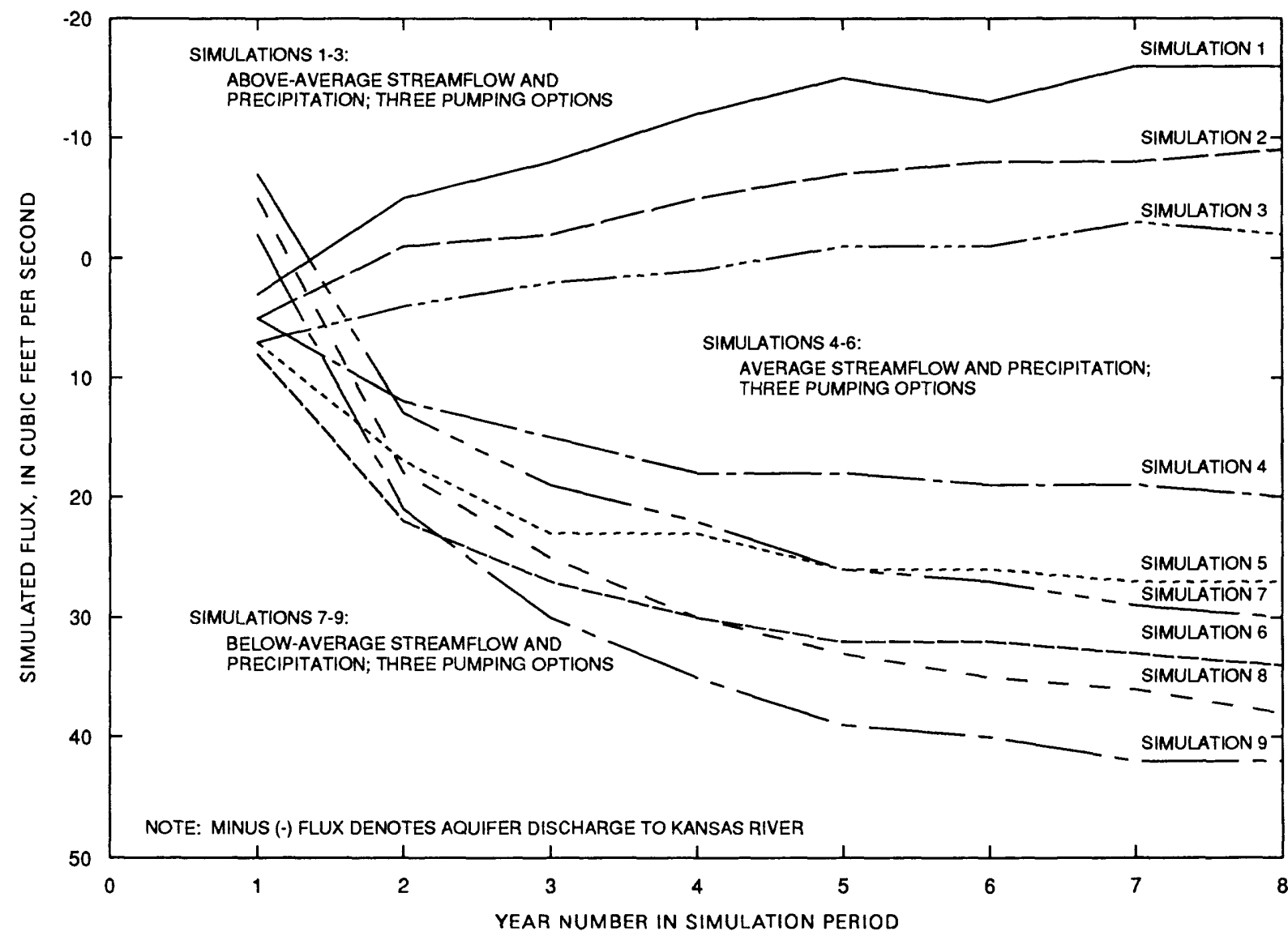

Figure 27. Annual mean net stream-aquifer leakage along entire Wamego-Topeka Kansas River reach for 8-year hypothetical simulations 1-9.

releases on the basis of the release discharge in cubic feet per second. The small release curves (solid lines on the graphs) represent slower traveltimes that include releases less than 700 cubic feet per second. The large releases (dashed lines on the graphs) represent faster traveltimes that include releases of more than 1,300 cubic feet per second. A line could be drawn connecting the first and last stations and would represent the average velocity of the rise to the last station downstream at which the release is identifiable. These overall average velocities are listed in table 4. Each plotted curve on the graphs is made up of segments between gaging stations. The slope of these segments represents the average velocity between each station. Many of the segments change slope, thus indicating variable velocities along the river for many of the release rises.

The graphs in figures 32 and 33 and the data in table 4 indicate a general trend that the greater the discharge of the release or of the antecedent discharge on the main stem, the faster will be the traveltime of the rise. Further inspection reveals that the larger the combination of the release discharge and the antecedent discharge on the main stem, the faster the traveltime. Because both release discharge and antecedent discharge are factors relating to depth of water in the river (larger release discharge or larger antecedent discharge generally cause deeper water in the river, up to a point), depth of water probably is a main factor affecting release rise-in-stage traveltimes. That is, the deeper the water in the river, the faster the traveltime of the reservoir-release rise.

Inspection of the graphs (figs. 32 and 33) shows that many of the curve segments change slope abruptly, thus causing one curve to cross over other curves. An increase in the rise-in-stage velocity as indicated by a more vertical slope on the graph could be due to one or more of many factors that may cause an increase in the depth of water in the river. Possible factors include an abrupt release of sewage effluent into the river or a tributary, 


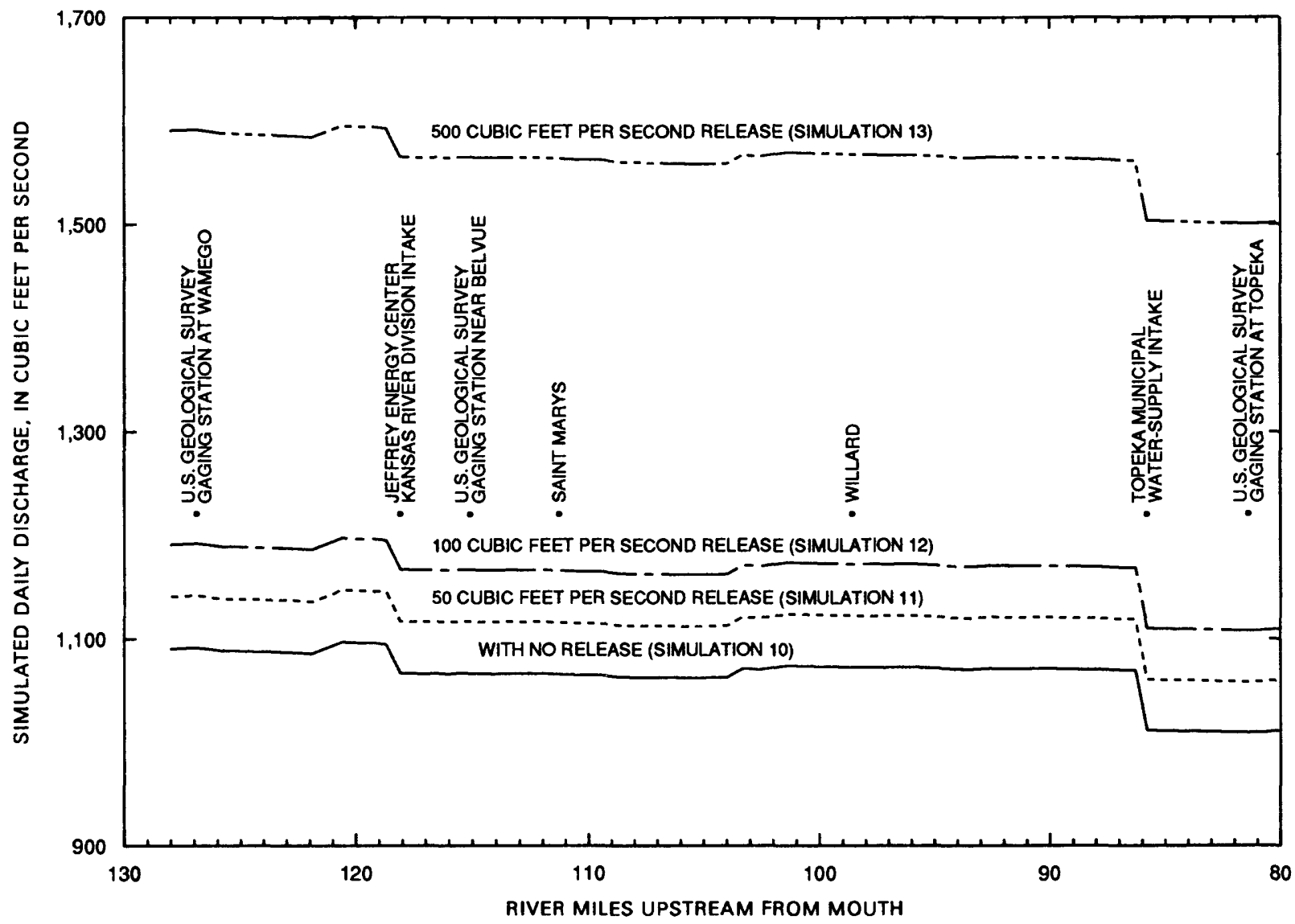

Figure 28. Effect of simulated reservoir releases during hypothetical drought conditions on August 8 in 8 th year of simulations.

precipitation in tributary headwaters, watermain breaks in towns or cities along the river or tributaries, an abrupt discharge of industrial cooling or holding ponds, farm ponds, swimming pools, or lakes, or an abrupt decrease in the rate of diversion from the river at various places, such as the Kansas Power and Light Jeffrey Energy Center intake near Beivue, the municipal water-supply intake at Topeka, or the several surface-water diversions for irrigation.

Conversely, a decrease in the rise-in-stage velocity as indicated by a more horizontal slope on the graph could be due to factors that may cause a decrease in the depth of water in the river. Possible factors include an abrupt increase in the diversion rate from points of diversion on the river, such as powerplants, municipal water-supply intakes, or irrigationdiversion intakes, or very large capacity wells located adjacent to the river for the purpose of inducing infiltration from the river. Some of the plotted release rises are traceable to only a short distance downstream because the rises cannot be recognized at subsequent downstream stations, probably due to any of the previously mentioned factors but also sometimes due to occasional equipment failure at the gaging stations.

Additional record searching and analysis, especially at low-flow times in other years, probably would yield data to fill in the gaps in the traveltime records and provide enough points for some statistical analysis of the data. Controlled releases at low-flow times are another way to fill in those gaps but would be very expensive for the small amount of data acquired. Analysis of the available historical records may be more economical than arranging for new reservoir releases under controlled conditions.

\section{SUMMARY}

The Kansas River valley alluvial aquifer between Wamego and Topeka, Kansas, underlies an area of about 135 square miles and 


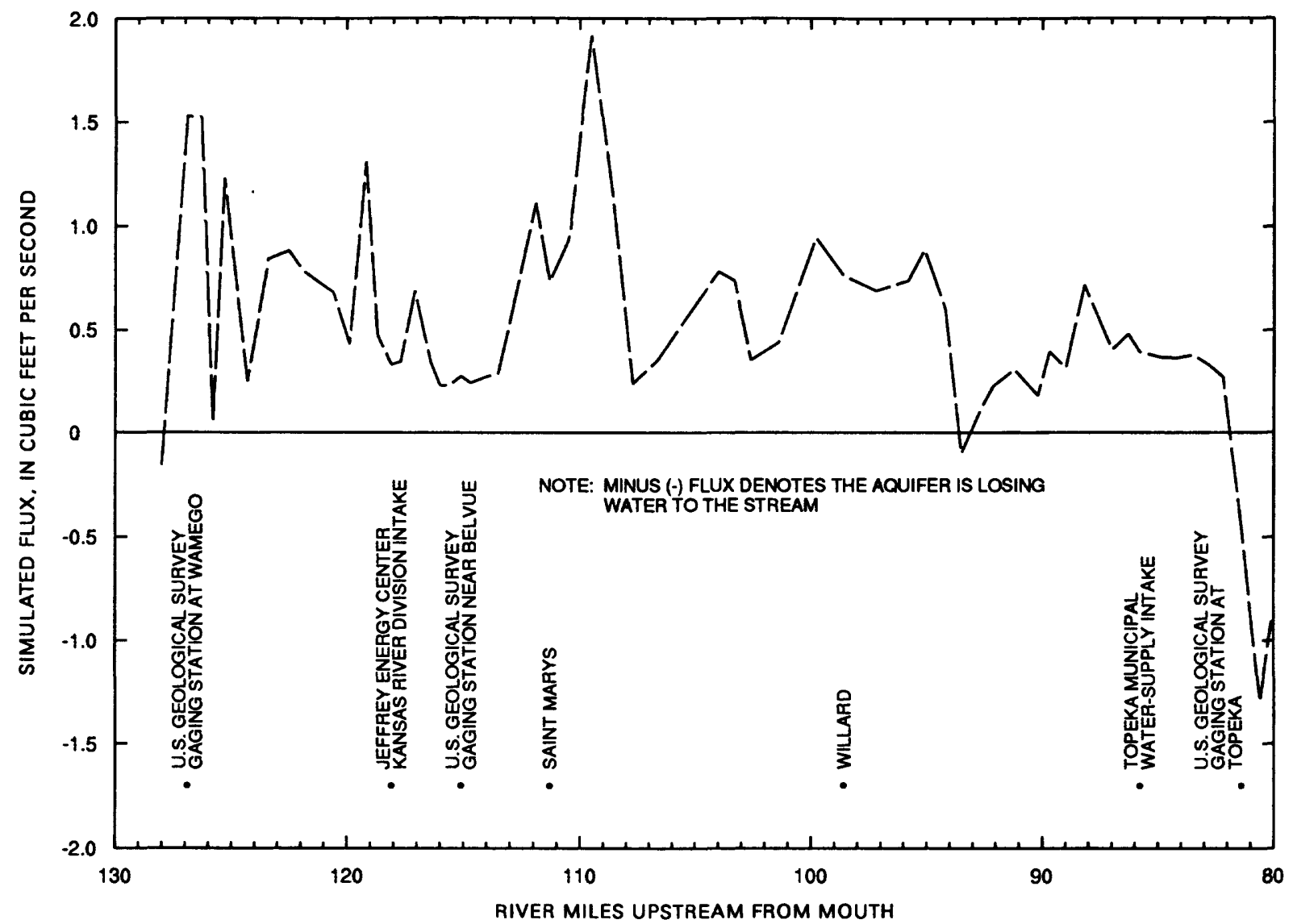

Figure 29. Stream-aquifer leakage at each model river node on August 8 (time step 220) in 8 th year of simulation 10 (hypothetical drought conditions).

has saturated thicknesses ranging from less than 1 foot at the valley walls to as much as $\mathbf{7 0}$ feet in the deepest part of the valley. Pumping from municipal, industrial, and irrigation wells has been sustained by the alluvial aquifer's capacity to store and yield large quantities of water.

A finite-element model was used to simulate transient conditions from 1948 to 1987 and to implement 8-year simulations with various hypothetical pumping options and simulated conditions of above-average, near-average, and below-average streamflow and precipitation. The model was calibrated primarily by comparisons of mapped 1956, 1967, and 1987 water-table contours and of hydrographs from 43 observation wells with simulated water levels. In general, measured and simulated water levels were comparable. Measured and simulated streamflows were compared for the Kansas River at Topeka. Generally, simulated streamflow agreed with measured discharge at the Topeka gaging station. The model simulation indicated that, on the average, precipitation, applied irrigation water, and lateral inflow are the major sources of aquifer recharge. Average recharge to the alluvial aquifer from 1948 to 1987 due to precipitation and application of irrigation water was about 84 cubic feet per second $(61,000$ acre-feet per year). Lateral inflow for 1948-87 was about 7 cubic feet per second $(5,100$ acre-feet per year).

Model results showed that the largest components of aquifer discharge are ground-water pumping, aquifer leakage to the main stem of the river, ground-water discharge to tributaries, ground-water evapotranspiration, and downgradient lateral outflow. The 1948-87 simulations indicated that average discharge from the aquifer due to these components was about 42 cubic feet per second $(30,000$ acre-feet per year) for ground-water pumping, 27 cubic feet per second $(20,000$ acre-feet per year) for aquifer leakage to the main stem of the river, 15 cubic feet per second $(11,000$ acre-feet per year) for discharge to 


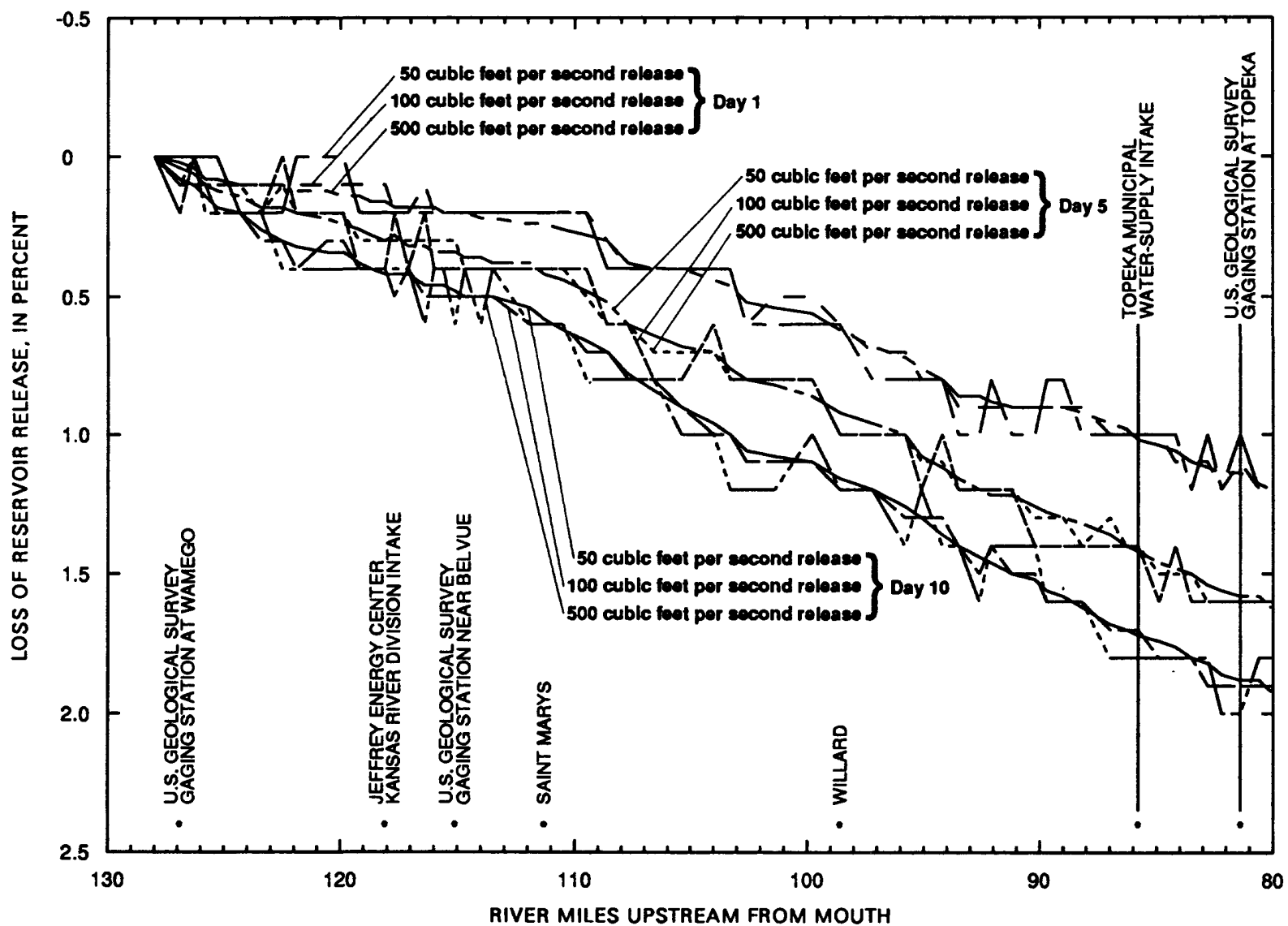

Figure 30. Percentage loss of simulated reservoir releases at each model river node on selected days (August 8, 12, and 17 in 8th year of simulation) after initial release.

tributaries, 9 cubic feet per second $(6,500$ acre-feet per year) for ground-water evapotranspiration, and 3 cubic feet per second $(2,200$ acre-feet per year) for net lateral outflow. The quantity of ground water used for irrigation in the modeled area has increased rapidly since the early 1950 's as shown by the steady increase (with substantial increases in the mid-1950's and mid-1970's) in the number of irrigation-well permits as compared to industrial and public-supply well permits.

Simulated recharge to the aquifer from all sources averaged about 98 cubic feet per second (71,000 acre-feet per year) for the 1948-87 period. Simulated discharges averaged about 96 cubic feet per second $(69,500$ acre-feet per year) during that period; thus, volume of water in storage increased at an average rate of about 2 cubic feet per second (1,500 acre-feet per year). Annual water-level variations reflect precipitation variations, and the average water-level rise across the area at the end of the 40-year simulation period was about 4 feet.
Results of simulated annual mean net stream-aquifer leakage during 1948-87 indicated that the aquifer generally discharged to the stream.

Sensitivity analysis indicated that simulated water levels are very sensitive to the precipitation variable and relatively insensitive to hydraulic conductivity, streambed leakance, and specific yield.

Thirteen 8-year model simulations used various hypothetical conditions of aboveaverage, near-average, and below-average years of streamflow and precipitation coupled with pumping options of continued 1987 groundwater withdrawals, a 50-percent increase of 1987 withdrawals, and a 100-percent increase of 1987 withdrawals. Resulting average simulated water-level changes were about 2 to 4 feet of rise for the above-average streamflow and precipitation simulations, about 2 to 4 feet of drawdown for the near-average conditions, and about 6 to 10 feet of drawdown for the 


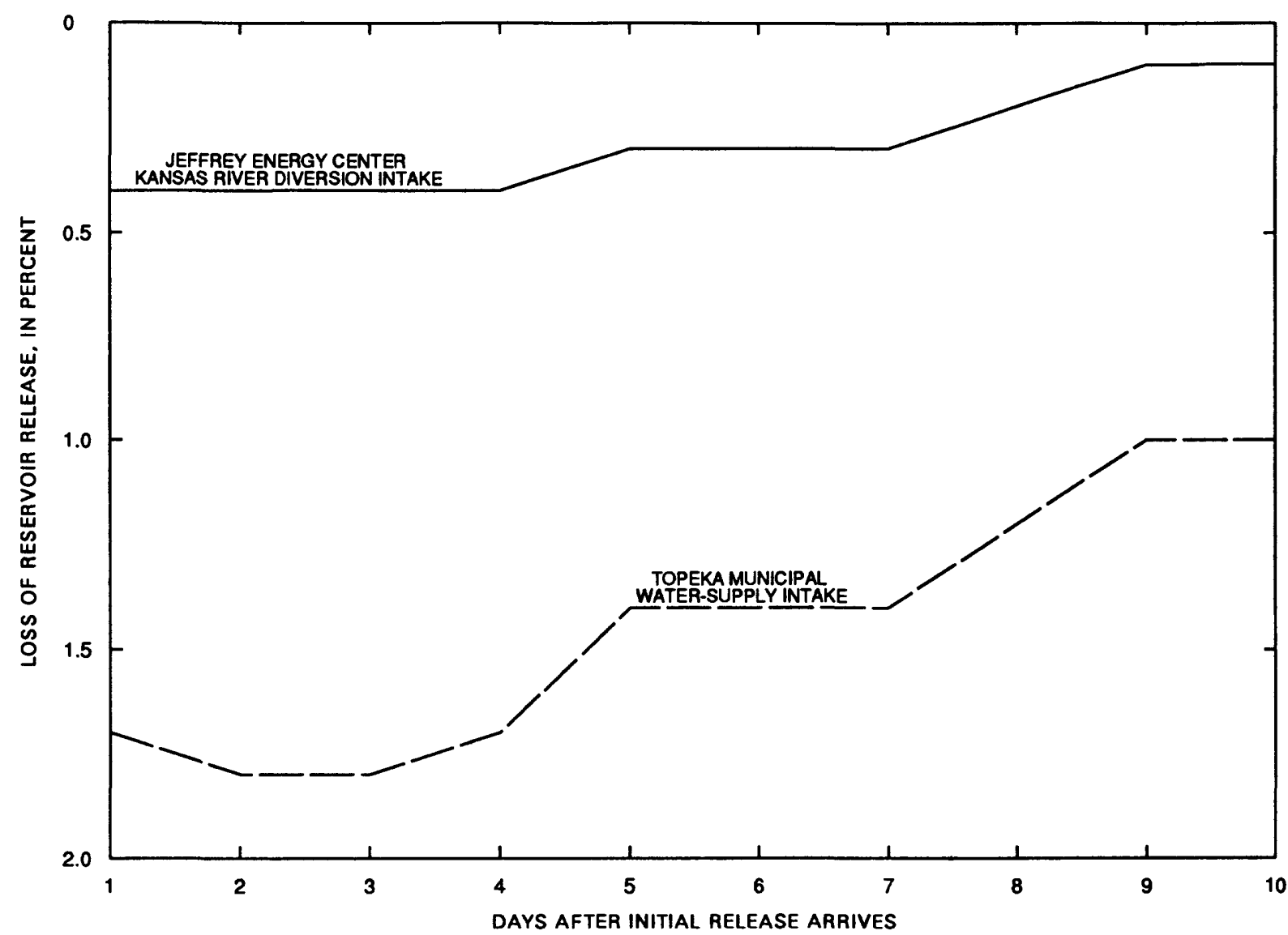

Figure 31. Percentage loss of simulated reservoir release of 100 cubic feet per second at selected points downstream during 10-day (August 8-17 in 8th year of simulation) release period.

below-average streamflow and precipitation conditions.

The below-average streamflow and precipitation simulation was the basis of comparison for simulated 10-day upstream reservoir releases of 50,100 , and 500 cubic feet per second during severe drought conditions. Model simulation showed that on the first day of the reservoir releases, the river is a losing stream at nearly all of the river nodes. The simulations indicate release losses of about $\mathbf{1 . 8}$ percent at the downstream end on the first day, about a 1.6-percent loss on the fifth day, and about a 1.2-percent loss on the tenth day as conditions in the stream-aquifer system approached a new equilibrium. Plots of the percentage loss indicated that the percentage of loss increased downstream from the release point, and the time necessary to reestablish equilibrium conditions after an initial reservoir release increased.
The model is a generalized, simplified representation of a complex hydrologic system. However, model results can be useful in evaluating hydrologic effects of various combinations of natural conditions, ground-water pumping rates, and upstream reservoir releases.

Analysis of actual historical traveltimes of reservoir-release rises in stage from Milford and Tuttle Creek Lakes indicated that, generally, the larger the release discharge or the larger the antecedent discharge on the main stem, the faster the rise in stage of the release traveled, thus indicating that the depth of the water in the river channel is the main factor affecting traveltimes. Many factors may cause increases or decreases in traveltimes between gaging stations, but overall average velocities calculated for the 31 releases analyzed ranged from 0.5 to 3.8 miles per hour. 
Table 4. Velocities for isolated historical reservoir-release rises from Milford and Tuttle Creek Lakes

\begin{tabular}{|c|c|c|c|c|}
\hline $\begin{array}{c}\text { Release } \\
\text { number (figs. } \\
32 \text { and } 33 \text { ) }\end{array}$ & $\begin{array}{l}\text { Date (month- } \\
\text { day-year) }\end{array}$ & $\begin{array}{c}\text { Release } \\
\text { discharge } \\
\text { (cubic feet per } \\
\text { second) }\end{array}$ & $\begin{array}{l}\text { Antecedent } \\
\text { flow of main } \\
\text { stem (cubic } \\
\text { feet per } \\
\text { second) }\end{array}$ & $\begin{array}{c}\text { Average } \\
\text { velocity to the } \\
\text { last station } \\
\text { (miles per } \\
\text { hour) }\end{array}$ \\
\hline \multicolumn{5}{|c|}{ Releases from Milford Lake } \\
\hline 1 & $07-17-86$ & 3,100 & 4,200 & 3.8 \\
\hline 2 & $07-16-86$ & 2,150 & 2,300 & 3.7 \\
\hline 3 & $11-09-79$ & 1,640 & 5,900 & 3.0 \\
\hline 4 & $07-15-76$ & 1,495 & 1,310 & 2.3 \\
\hline 5 & $12-01-86$ & 1,440 & 1,570 & 2.3 \\
\hline 6 & $07-05-85$ & 1,404 & 1,610 & 2.0 \\
\hline 7 & $01-24-86$ & 340 & 917 & 2.0 \\
\hline 8 & $08-11-77$ & 681 & 2,390 & 1.8 \\
\hline 9 & $01-30-76$ & 130 & 568 & 1.8 \\
\hline 10 & $08-28-76$ & 245 & 460 & 1.6 \\
\hline 11 & $10-18-86$ & 94 & 400 & 1.4 \\
\hline 12 & $04-18-77$ & 18 & 355 & 1.1 \\
\hline 13 & $11-17-86$ & 48 & 415 & 1.2 \\
\hline 14 & $12-16-86$ & 30 & 385 & .5 \\
\hline \multicolumn{5}{|c|}{ Releases from Tuttle Creek Lake } \\
\hline 15 & $06-12-86$ & 2,020 & 5,300 & 2.5 \\
\hline 16 & 03-06-85 & 3,270 & 3,900 & 2.4 \\
\hline 17 & $06-10-86$ & 2,785 & 3,000 & 2.3 \\
\hline 18 & $03-22-80$ & 3,513 & 1,730 & 2.3 \\
\hline 19 & 04-07-86 & 1,350 & 2,500 & 2.1 \\
\hline 20 & $07-25-85$ & 7,025 & 2,240 & 2.0 \\
\hline 21 & 07-23-76 & 375 & 4,310 & 1.9 \\
\hline 22 & $05-14-80$ & 515 & 2,680 & 1.8 \\
\hline 23 & $09-07-80$ & 140 & 1,290 & 1.8 \\
\hline 24 & $06-14-79$ & 330 & 2,560 & 1.8 \\
\hline 25 & $07-14-80$ & 555 & 2,420 & 1.8 \\
\hline 26 & $09-15-81$ & 416 & 2,020 & 1.8 \\
\hline 27 & $08-01-80$ & 213 & 1,720 & 1.7 \\
\hline 28 & $02-06-85$ & 275 & 2,100 & 1.6 \\
\hline 29 & $08-19-80$ & 155 & 890 & 1.7 \\
\hline 30 & $05-12-88$ & 211 & 920 & 1.5 \\
\hline 31 & $10-31-84$ & 457 & 745 & 1.5 \\
\hline
\end{tabular}




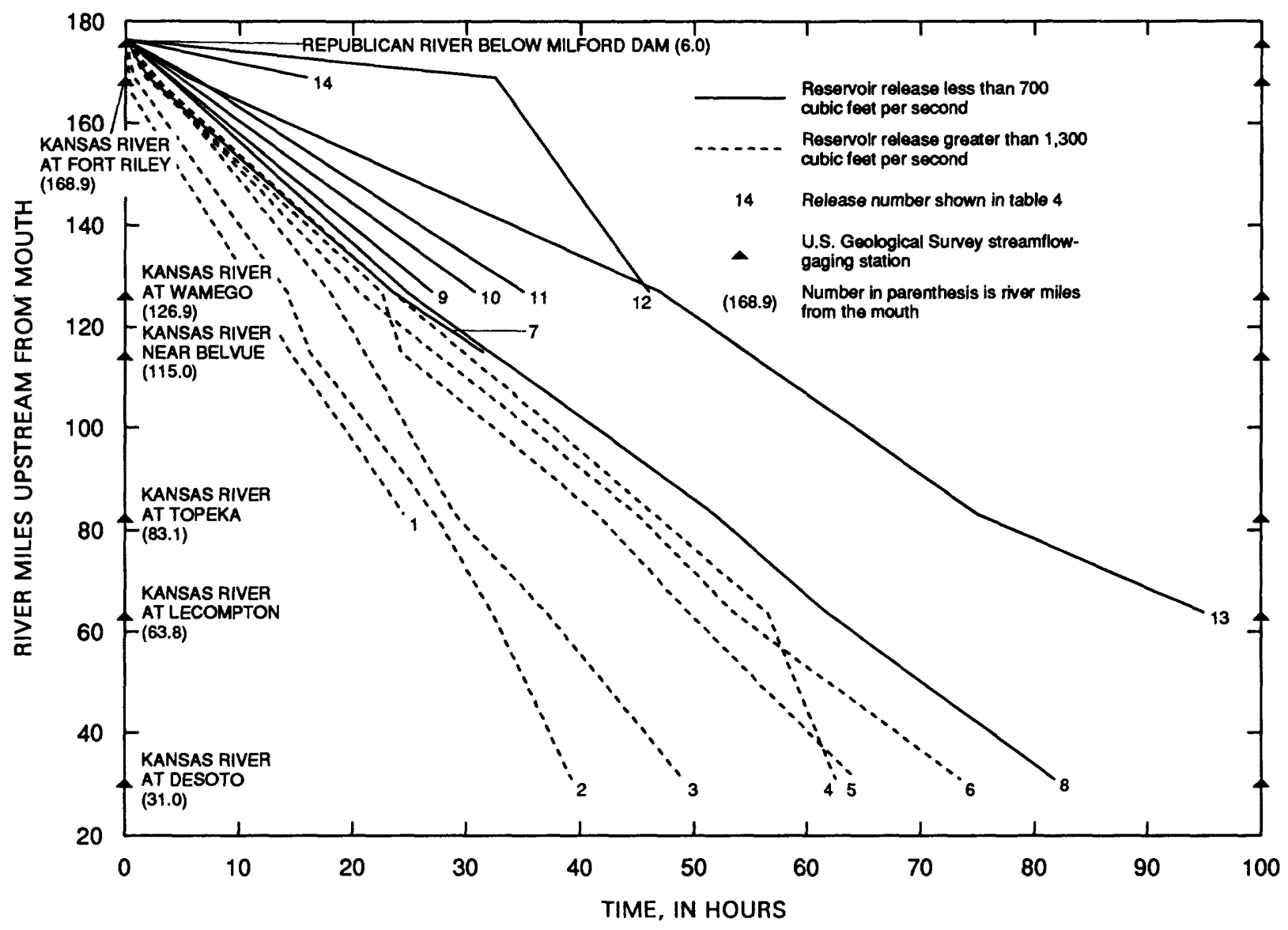

Figure 32. Traveltime of selected historical reservoir-release rises from Milford Lake.

\section{SELECTED REFERENCES}

Beck, H.V., 1959, Geology and ground-water resources of the Kansas River valley between Wamego and Topeka vicinity: Kansas Geological Survey Bulletin 135, $88 \mathrm{p}$.

Desai, C.S., and Abel, J.F., 1972, Introduction to the finite-element method: New York, Van Nostrand Reinhold, $477 \mathrm{p}$.

Dunlap, L.E., Lindgren, R.J., and Carr, J.E., 1984, Projected effects of ground-water withdrawals in the Arkansas River valley, 1980-1999, Hamilton and Kearny Counties, southwestern Kansas: U.S. Geological Survey Water-Resources Investigations Report 84-4082, $168 \mathrm{p}$.

Fader, S.W., 1974, Ground water in the Kansas River valley, Junction City to Kansas City, Kansas: Kansas Geological Survey Bulletin
206, part 2, 12 p.

Jensen, M.E., and Haise, H.R., 1963, Estimating evapotranspiration from solar radiation: American Society of Civil Engineers, Journal of Irrigation and Drainage Division, v. 89, p. $15-41$.

Jewett, J.M., O'Connor, H.G., and Seevers, W.J., 1965, Hydrogeology of the lower Kansas River valley--A field conference guidebook for the 1965 annual meetings: Kansas City, Missouri, Geological Society of America and Associated Societies, 45 p.

National Oceanic and Atmospheric Administration, 1951-80, Climatological data, Kansas, annual summary: Asheville, N.C., National Climatic Center (published annually). 


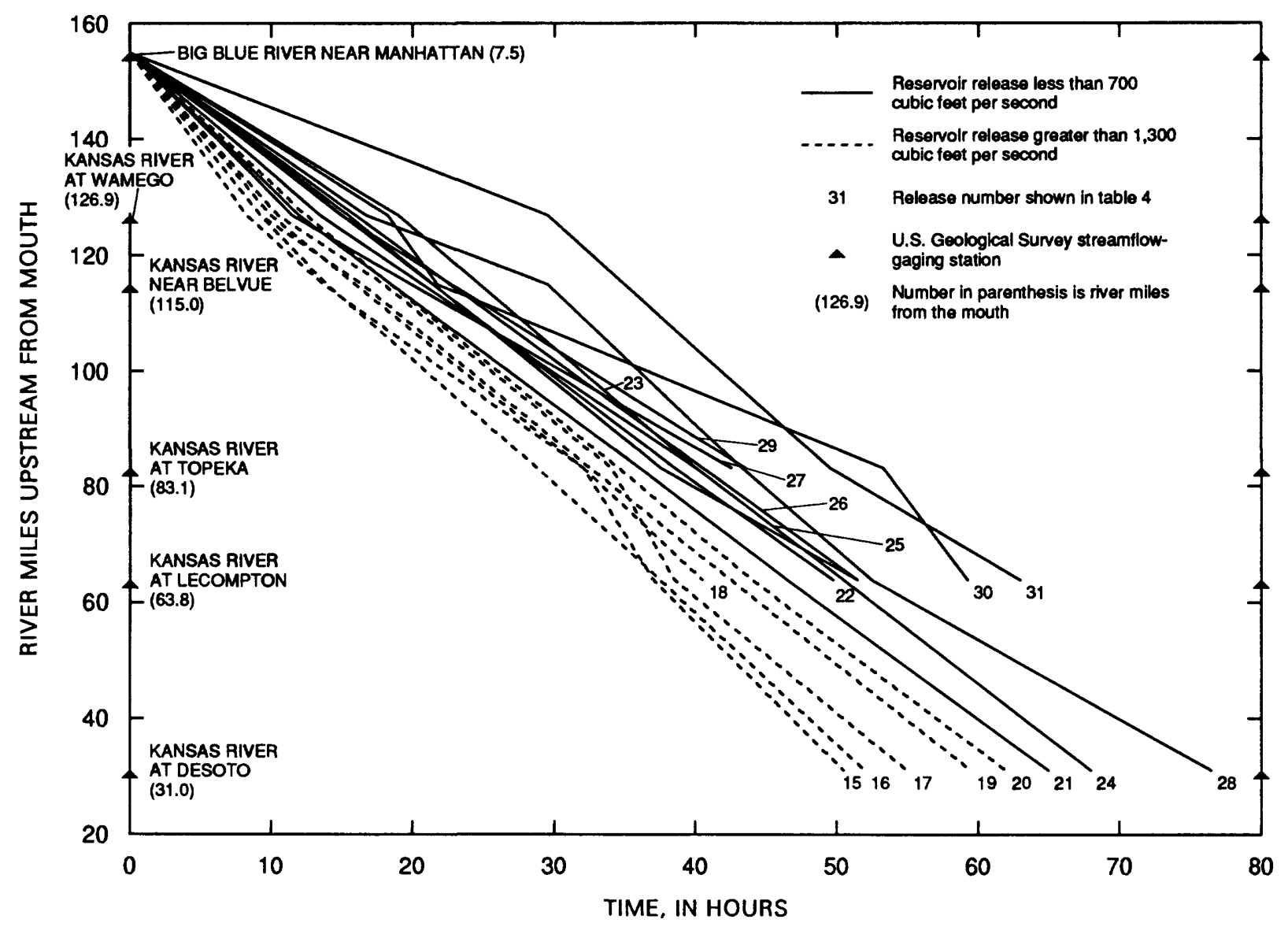

Figure 33. Traveltime of selected historical reservoir-release rises from Tuttle Creek Lake.

Otradovsky, F.J., 1986, Program "BASIN2" users manual: Grand Island, Nebr., U.S. Bureau of Reclamation, Central Nebraska Projects Office, $121 \mathrm{p}$.

U.S. Department of Agriculture, 1967, Irrigation water requirements: Soil Conservation Service Technical Release 21, p. 22-28.

U.S. Geological Survey, 1952, Kansas-Missouri floods of July 1951: U.S. Geological Survey Water-Supply Paper 1139, 239 p.

Weaver, William, Jr., 1967, Computer programs for structural analysis: Princeton, New
Jersey, D. Van Nostrand, 300 p.

Wexler, E.J., and Maus, P.E., 1988, Ground-water flow and solute transport at a municipal landfill site on Long Island, New York--Part 2, Simulation of ground-water flow: U.S. Geological Survey WaterResources Investigations Report 86-4106, $44 \mathrm{p}$.

Winslow, J.D., and Nuzman, C.E., 1966, Electronic simulation of ground-water hydrology in the Kansas River valley near Topeka, Kansas: Kansas Geological Survey Special Distribution Publication 29, 24 p. 